\title{
gdhB, a gene encoding a second quinoprotein glucose dehydrogenase in Pantoea citrea, is required for pink disease of pineapple
}

\author{
Catherine J. Pujolt and Clarence I. Kado \\ Author for correspondence: Clarence I. Kado. Tel: + 1530752 0325. Fax: + 15307525674. \\ e-mail : cikado@ucdavis.edu
}

Department of Plant Pathology, University of California, Davis, CA 95616, USA

\begin{abstract}
The pink disease of pineapple, caused by the bacterium Pantoea citrea, is characterized by a dark coloration on fruit slices after canning. A glucose dehydrogenase ( $G d h$ ) encoded by the gdhA gene has been implicated in the colour formation activity of $P$. citrea. In this paper it has been shown that $P$. citrea contains a second, homologous gdh gene and its product, GdhB, represents the main source of Gdh activity in this organism. Unlike gdhA, gdhB is constitutively expressed during the exponential phase of growth and is induced in stationary phase. A previously isolated chemical mutant, CMC6, which is deficient in Gdh activity and pink disease formation, failed to express gdhB during the stationary phase of growth. The CMC6 mutant can be complemented by a 54 bp DNA fragment located upstream of gdhA. This fragment, which contains an operator-like 11 bp inverted repeat, strongly enhances the expression of gdhA, probably by titrating away a negative effector of its expression. These results illustrate the complex interplay operating between the two gdh genes and emphasize the role of glucose metabolism in the pathway leading to pink disease.
\end{abstract}

Keywords: Pantoea, pink disease, glucose dehydrogenase

\section{INTRODUCTION}

Pink disease of pineapple is characterized by a dark coloration of the pineapple flesh when the fruit is canned (Rohrbach, 1989). The fruits, however, remain superficially asymptomatic in the field, making it difficult to discriminate between diseased and healthy fruits. Recently, a bacterium isolated in the Philippines was shown to be responsible for pink disease and identified as Pantoea citrea (Cha et al., 1997b). This bacterium belongs to the Enterobacteriaceae and is mainly found in fruits and soil samples (Sonoyama et al., 1988; Kageyama et al., 1992). The genes of $P$. citrea involved in pathogenesis are currently being identified and characterized (Cha et al., 1997a; Pujol \& Kado, 1998). We previously generated a nitrosoguanidine-mediated mutant of $P$. citrea called CMC6, which was unable to

\footnotetext{
†Present address: Medical Pathology Department, UCD Medical Center, Room 3300A, 4645 2nd Avenue, Sacramento, CA 95817, USA

Abbreviations: CRP, CAMP receptor protein; Gdh, glucose dehydrogenase; $P Q Q$, pyrroloquinoline quinone.

The EMBL accession numbers for the sequences reported in this paper are AF050503 (gdhB) and X95985 (gdhA).
}

induce the dark coloration characteristic of pink disease. This mutant could be complemented by a $3.9 \mathrm{~kb}$ genomic DNA fragment containing a gene encoding a glucose dehydrogenase (Gdh) (Cha et al., 1997a). This gene, designated $g d h A$, is homologous to various bacterial Gdh genes. Its product, GdhA, belongs to the quinoprotein-glucose dehydrogenase family, whose members are usually associated with the cytoplasmic membrane, require pyrroloquinoline quinone (PQQ) as a cofactor (Duine et al., 1979), oxidize D-glucose to Dgluconate in the periplasm and can also oxidize aldoses and disaccharides in Pseudomonas stutzeri LMD26-38 (Cleton-Jansen et al., 1988) and Acinetobacter calcoaceticus (Cleton-Jansen et al., 1989), respectively. PQQdependent Gdhs are synthesized in a wide variety of bacterial species, some of which are able to synthesize PQQ, such as A. calcoaceticus (Duine et al., 1979), Pseudomonas fluorescens (Ameyama et al., 1981), Klebsellia aerogenes (Neijssel et al., 1983), Gluconobacter oxydans (Buchert \& Viikari, 1988) and Erwinia herbicola (Liu et al., 1992), while others such as Escherichia coli (Hommes et al., 1984), Klebsiella pneumoniae (Hommes et al., 1989) and Acinetobacter lwoffii (Van Schie et al., 1984) synthesize only the 
apoenzyme whose activity is dependent on an exogenous source of PQQ (Van Schie et al., 1985).

The role of Gdh in glucose metabolism differs between various organisms. Some organisms use a modified Entner-Doudoroff metabolic pathway to oxidize glucose to gluconate and 2-ketogluconate, which in turn are phosphorylated into 6-phosphogluconate and 2-keto-6phosphogluconate, respectively (Conway, 1992). In E. coli, the enzymes of the Entner-Doudoroff pathway are induced either by glucose and PQQ (Fliege et al., 1992) or by gluconate (reviewed by Fraenkel, 1996). A number of Acetobacter, Erwinia, Gluconobacter and Pantoea species can oxidize gluconate further into 2-ketogluconate and then into 2,5-diketogluconate by a membrane-bound gluconate dehydrogenase and a 2ketogluconate dehydrogenase, respectively (Matsushita et al., 1982; Shinagawa et al., 1984; Sonoyama et al., 1988; Yum et al., 1997). Likewise, P. citrea forms 2,5diketogluconate as the end product of glucose oxidation (C. Pujol \& C. Kado, unpublished).

We found that elimination of the $g d h A$ gene, which was previously thought to be responsible for pink disease (Cha et al., 1997a), did not dramatically reduce Gdh activity and pink colour formation, suggesting that another $g d h$ gene may be involved. This was verified by genetic analyses which revealed the presence of a second gdh gene, $g d h B$, whose product, GdhB, is shown here to be the primary enzyme involved in Gdh activity linked to pink disease development.

\section{METHODS}

Bacterial strains, media, growth conditions and antibiotics. Bacterial strains used are listed in Table 1. E. coli strains were grown at $37^{\circ} \mathrm{C}$ in LB or M9 media (Sambrook et al., 1989) and $P$. citrea strains at $30^{\circ} \mathrm{C}$ in LB medium containing rifampicin, Mannitol/Glutamate/Yeast (MGY) medium or pineapple juice (Cha et al., 1997a). Media were solidified with $1.5 \%$ Bacto-agar (Difco). E. coli and P. citrea were transformed by electroporation as described previously (Cha et al., 1997a). Transformants were selected on LB agar containing $100 \mu \mathrm{g}$ ampicillin $\mathrm{ml}^{-1}, 40 \mu \mathrm{g} \mathrm{X}-\mathrm{Gal} \mathrm{ml^{-1 }}$ (Denville) and $0 \cdot 1 \mathrm{mM}$ IPTG (Gibco-BRL). Antibiotics (Sigma) were used as follows $\left(\mu \mathrm{g} \mathrm{ml}^{-1}\right)$ : rifampicin (Rif), 100; chloramphenicol $(\mathrm{Cm}), 25$ and 20; tetracycline (Tc), 15 and 10; ampicillin (Ap), 250 and 100 for $P$. citrea and $E$. coli, respectively.

Plasmids and DNA manipulations. Cloning vectors and plasmids used are listed in Table 1. Plasmid screening was carried out by alkaline lysis (Birnboim, 1983). Plasmid DNAs were prepared using the Qiagen plasmid kit. Total DNA was purified as described by te Riele et al. (1986). Purified DNAs were cleaved with restriction endonucleases as specified by the suppliers (Boehringer Mannheim or New England Biolabs). Ligations were performed with T4 DNA ligase (Boehringer Mannheim) and nested deletions were constructed by using exonuclease III and S1 nuclease (Boehringer Mannheim) according to standard protocols (Sambrook et al., 1989).

DNA hybridization and sequencing. Southern blot hybridizations were performed as described by Sambrook et al. (1989) and were carried out at $65^{\circ} \mathrm{C}$ with Rapid-Hyb Buffer (Amersham). Probes were prepared by nick-translation (Boehringer Mannheim) using $\left[\alpha^{32} \mathrm{P}\right] \mathrm{dCTP}$ (DuPont-NEN Products). dsDNA sequences were determined by the dideoxy chain-termination method (Sanger et al., 1977) using the Sequenase version $2.0 \mathrm{kit}$ (USB) and $\left[\alpha^{-{ }^{35}} \mathrm{~S}\right] \mathrm{dATP}$ (DuPontNEN Products), as described previously (Pujol \& Kado, 1998). Sequence compilation and comparative analyses were made with the Genetics Computer Group program version 9.0 (University of Wisconsin, Madison).

Pink disease test and enzyme assay. The pink disease test was performed in pineapple juice as described previously (Cha et al., 1997a). Briefly, P. citrea was grown in pineapple juice for $3 \mathrm{~d}$ at $30^{\circ} \mathrm{C}$. The culture was then autoclaved for $5 \mathrm{~min}$ at $121{ }^{\circ} \mathrm{C}$ and the cells were removed by centrifugation $(10000 \mathrm{~g}$, $5 \mathrm{~min}$ ). The absorbance of the clarified supernatant was determined spectrophotometrically at $420 \mathrm{~nm}$.

Gdh activity in vivo was detected on MGY agar containing $2 \%$ glucose and eosin yellow/methylene blue (Cha et al., 1997 a). In vitro activity was measured as follows: cells were cultured in $20 \mathrm{ml} \mathrm{LB}$ medium for $72 \mathrm{~h}$ at $30^{\circ} \mathrm{C}$, collected by centrifugation $(5000 \mathrm{~g}, 10 \mathrm{~min})$, resuspended in $2 \mathrm{ml}$ lysis buffer $(0 \cdot 1 \mathrm{M}$ Tris $/ \mathrm{HCl}$, pH 7.0, $10 \mathrm{mM}$ EDTA, $0 \cdot 1 \%$ PMSF, $5 \mathrm{mg}$ lysozyme $\mathrm{ml}^{-1}$ ) and incubated for $30 \mathrm{~min}$ at $37^{\circ} \mathrm{C}$. The entire mixture was then lysed by sonication using a MS50 sonicator (Heat Systems-Ultrasonics). Cell debris were removed by centrifugation $(8000 \mathrm{~g}, 10 \mathrm{~min})$. Total protein content was determined with a Protein (Bradford) assay kit (Bio-Rad). Samples of $100 \mu \mathrm{l}$ of cell extracts were mixed with assay buffer $[0 \cdot 1 \mathrm{M}$ Tris $/ \mathrm{HCl}, \mathrm{pH} 7 \cdot 2,0 \cdot 1 \mathrm{mg}$ Wurster's Blue

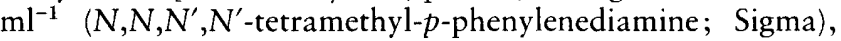
$50 \mathrm{mM}$ glucose]. Gdh activity was measured spectrophotometrically at $610 \mathrm{~nm}$. Calculations of Gdh activity were based on the molar extinction coefficient for Wurster's Blue of $12400 \mathrm{M}^{-1} \mathrm{~cm}^{-1}$ at $610 \mathrm{~nm}$ (Dokter et al., 1986).

Identification of $\mathbf{g d h} \mathbf{B}$ - insertional mutation of $\mathbf{g d h A}$ and gdhB. For $g d h A$, an internal $1750 \mathrm{bp} \mathrm{Hpal} \mathrm{fragment} \mathrm{was}$ removed from a 3875 bp DNA fragment containing the $g d h A$ gene previously cloned in pUCD5723 (Cha et al., 1997a), resulting in plasmid pUCD5020. A 2168 bp Haell-XbaI fragment carrying the chloramphenicol acetyl transferase gene (cat) of plasmid pACYC184 was treated with the Klenow fragment of $E$. coli DNA polymerase I and cloned into the unique HpaI site of pUCD5020, resulting in plasmid pUCD5021. The $3645 \mathrm{bp}$ AatII-HindIII fragment of pUCD5021, containing the cat gene and partial sequences of gdhA, was cloned into the Sall site of the integrative plasmid pUCD5700 after treatment with the Klenow enzyme, generating plasmid pUCD5022 in E. coli S17-1 $\lambda$ pir. P. citrea $1056 \mathrm{R}$ cells were transformed with pUCD5022 and plated on $\mathrm{LB}$ agar plates containing Rif and $\mathrm{Cm}$. Selection of insertion mutants was based on $\mathrm{Cm}^{\mathrm{r}}$ and $\mathrm{Ap}^{\mathrm{s}}$. Total DNA from an overnight culture of the putative mutants was purified, digested with BamHI and EcoRI, analysed by agarose gel electrophoresis and transferred onto a Hybond-N+ Nylon membrane (Amersham). The DNA was then hybridized with $a^{32} \mathrm{P}$-labelled probe containing the Bam $\mathrm{HI}-E c o \mathrm{RI}$ fragment of pUCD5723 carrying gdhA (Cha et al., 1997a). One mutant, designated $1058 \mathrm{RC}$, was selected. Inactivation of $g d h A$ in strain CMC6 was carried out in the same way. One Rif $\mathrm{Cm}^{r}$ $\mathrm{Ap}^{\mathrm{s}}$ strain (1062RC) was selected and the disruption of $\mathrm{gdhA}$ was verified by Southern blot hybridization.

To identify a putative second $g d h$ gene, we used the genomic DNA of strain 1058RC ( $\Delta g d h A:: c a t)$ as template in PCR reactions using two 18-mer degenerate oligonucleotides representing 48 different sequences: pqq2 5'-CTGCCAGTDAACGAYGGYCGYCTG-3' and pqq4 5' -TTCRTARGTCATYGGRGTHGCCTG-3', where $\mathrm{R}$ represents any purine, $\mathrm{Y}$ represents any pyrimidine, D represents $T, A$ or $G$, and $H$ represents A, T or C. Amplification cycles $\left(5\right.$ cycles of $94^{\circ} \mathrm{C}$ 
Table 1. Bacterial strains and plasmids used

\begin{tabular}{|c|c|c|}
\hline Strain & Genotype or phenotype & Source or reference \\
\hline \multicolumn{3}{|l|}{ Escherichia coli } \\
\hline $\mathrm{DH} 5 \alpha$ & $\begin{array}{l}\text { hsdR17 }\left(\mathrm{r}_{\mathrm{k}}^{-} \mathrm{m}_{\mathrm{k}}^{+}\right) \Delta(\text { lacZYA-argF) } \mathrm{U} 169 \text { } \phi 80 \mathrm{~d} l a c Z \Delta \mathrm{M} 15 \text { supE44 thi-1 recA1 } \\
\text { endA1 gyrA96 relA1 }\end{array}$ & Sambrook et al. $(1989)$ \\
\hline S17-1 i pir & 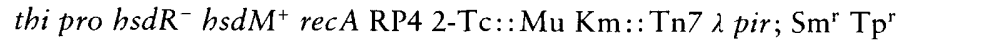 & Simon et al. (1983) \\
\hline \multicolumn{3}{|c|}{$\mathrm{C}^{\mathrm{S}}$} \\
\hline 1056R & Wild-type, Rifr & Cha et al. (1997b) \\
\hline $1058 \mathrm{RC}$ & $\Delta g d h A:: c a t ; \operatorname{Rif}^{r} \mathrm{Cm}^{r}$ & This study \\
\hline 1060RT & gdbB: :tet; Rifr $\mathrm{Tc}^{\mathrm{r}}$ & This study \\
\hline 1061RCT & $\Delta g d h A::$ cat $g d b B::$ tet $; \operatorname{Rif}^{r} \mathrm{Tc}^{\mathrm{r}} \mathrm{Cm}^{\mathrm{r}}$ & This study \\
\hline CMC6 & Chemical mutant; Gdh pink $^{-} ;$Rif $^{r}$ & Cha et al. $(1997 \mathrm{~b})$ \\
\hline 1062RC & Derivative of CMC6; $\Delta g d h A::$ cat; Rif $^{r} \mathrm{Cm}^{\mathrm{r}}$ & This study \\
\hline 1063RT & Derivative of CMC6; gdbB::tet; Rif ${ }^{\mathrm{r}} \mathrm{Tc}^{\mathrm{r}}$ & This study \\
\hline \multicolumn{3}{|c|}{ ( } \\
\hline pBluescript SKII(-) & ColE1 origin; $\mathrm{Ap}^{\mathrm{r}}$ & Stratagene \\
\hline pACYC184 & p15A origin; $\mathrm{Tc}^{\mathrm{r}} \mathrm{Cm}^{\mathrm{r}}$ & New England Biolabs \\
\hline pBR322 & $\operatorname{Tc}^{r} A p^{r}$ & New England Biolabs \\
\hline pUCD5700 & R6K origin Mob RP4; Ap ${ }^{r}$ & J.-S. Cha, unpublished \\
\hline pUCD5723 & Derivative of pBR322; gdhA (3875 bp); $\mathrm{Ap}^{r} \mathrm{Tc}^{r}$ & Cha et al. (1997a) \\
\hline pUCD5020 & Derivative of pUCD5723; gdhALHpaI (2125 bp); Ap ${ }^{r} \mathrm{Tc}^{r}$ & This study \\
\hline pUCD5021 & Derivative of pUCD5020; gdhA $\triangle H p a \mathrm{I}:$ : cat $(3448 \mathrm{bp}) ; \mathrm{Cm}^{r} \mathrm{Ap}^{\mathrm{r}} \mathrm{Tc}^{\mathrm{r}}$ & This study \\
\hline pUCD5022 & Derivative of pUCD $5700 ;$ gdhA $\Delta H p a \mathrm{I}::$ cat $(3448 \mathrm{bp}) ; \mathrm{Cm}^{\mathrm{r}} \mathrm{Ap}^{\mathrm{r}}$ & This study \\
\hline pUCD5026 & Derivative of pUCD $5723 ; \Delta B g l \mathrm{II}-\mathrm{N} c o \mathrm{I}(2865 \mathrm{bp}) ; \mathrm{Ap}^{\mathrm{r}} \mathrm{Tc}^{r}$ & This study \\
\hline pUCD5027 & $\begin{array}{l}\text { Derivative of pBluescript SKII }(-) ; B g l \mathrm{II}-\mathrm{Ncol} \text { from pUCD5723 (1010 bp); } \\
\mathrm{Ap}^{\mathrm{r}}\end{array}$ & This study \\
\hline pUCD5035 & Derivative of pUCD5027 $(846 \mathrm{bp}) ; \mathrm{Ap}^{\mathrm{r}}$ & This study \\
\hline pUCD5046 & Derivative of pUCD5027 $(790 \mathrm{bp}) ; \mathrm{Ap}^{\mathrm{r}}$ & This study \\
\hline pUCD5058 & Derivative of pUCD5027 (203 bp); Ap ${ }^{r}$ & This study \\
\hline pUCD5059 & Derivative of pUCD5027 (117 bp); Ap ${ }^{r}$ & This study \\
\hline pUCD5061 & Derivative of pBluescript SKII $(-) ; 54$ bp upstream of $g d h A ; \mathrm{Ap}^{\mathrm{r}}$ & This study \\
\hline pUCD5062 & As for pUCD5061 but with inverse orientation of the $54 \mathrm{bp}$ fragment; $\mathrm{Ap}^{\mathrm{r}}$ & This study \\
\hline pUCD5063 & Derivative of pBluescript SKII $(-)$; partial $g d h B(1387 \mathrm{bp}) ; A^{r}$ & This study \\
\hline pUCD5080 & Derivative of pUCD5063 (2727 bp); Ap ${ }^{r} \mathrm{Tc}^{r}$ & This study \\
\hline pUCD6702 & Derivative of pUCD 5700 ; partial gdhB $(2727 \mathrm{bp})$; $\mathrm{Ap}^{\mathrm{r}} \mathrm{Tc}^{\mathrm{r}}$ & This study \\
\hline pUCD6712 & Derivative of pBluescript SKII $(-) ; g d h A(2504 \mathrm{bp}) ; \mathrm{Ap}^{\mathrm{r}}$ & This study \\
\hline pUCD6715 & Derivative of pBluescript SKII $(-) ; g d h B(2703 \mathrm{bp}) ; \mathrm{Ap}^{\mathrm{r}}$ & This study \\
\hline
\end{tabular}

for $1 \mathrm{~min}, 42^{\circ} \mathrm{C}$ for $1 \mathrm{~min}$ and $72^{\circ} \mathrm{C}$ for $1 \mathrm{~min}$, then 25 cycles of $94^{\circ} \mathrm{C}$ for $1 \mathrm{~min}, 50^{\circ} \mathrm{C}$ for $1 \mathrm{~min}$ and $72^{\circ} \mathrm{C}$ for $2 \mathrm{~min}$ ) were carried out with Taq polymerase (Promega). The amplified fragment was cloned into pBluescript $\operatorname{SKII}(-)$ resulting in plasmid pUCD5063. A 1340 bp HindIII-StyI fragment from pBR322, containing the tetracycline resistance gene (tet), was cloned into the unique BstEII site of pUCD5063 after treatment with Klenow polymerase, resulting in plasmid pUCD5080. A 2752 bp fragment containing partial sequences of $g d h B$ and the tet gene was amplified using Pfu DNA polymerase (Stratagene) and primers gdhPCR $15^{\prime}$-TTCGTAAGATCTCGGGGTTGCCTGACCACCC-3' and gdhPCR2 5'-TTAACGAGATCTGCCTGATTGCGGTGGATGC-3'. The underlined nucleotides correspond to BglII restriction sites. The amplified fragment was digested with $B g l \mathrm{II}$ and cloned into the unique BglII site of the integrative vector pUCD5700, to produce plasmid pUCD6702 in E. coli S17-1 $\lambda$ pir. $P$. citrea 1056R competent cells were transformed with pUCD6702 and plated on LB agar plates containing Rif and $15 \mu \mathrm{g} \mathrm{Tc} \mathrm{ml} \mathrm{m}^{-1}$. Insertion mutants were selected for $\mathrm{Tc}^{r}$ and $\mathrm{Ap}^{\mathrm{s}}$. Mutants were checked by Southern blot hybridization using the $2.8 \mathrm{~kb}$
XbaI-HindIII fragment of pUCD5080 as probe. One mutant, designated 1060RT, containing an insertion in $g d h B$ was selected. $g d h B$ was also inactivated using the same approach in strain CMC6, resulting in strain 1063RT. A double $g d h A^{-}$ $g d h B^{-}$mutant was obtained by transforming $P$. citrea $1058 \mathrm{RC}$ with plasmid pUCD6702. Mutants were selected for $\mathrm{Cm}^{r}, \mathrm{Tc}^{r}$ and $A p^{s}$ and checked by Southern blot hybridization as described above. One mutant strain, 1061RCT, was selected. Cloning of $\mathbf{g d h A}$ and $\boldsymbol{g d h \boldsymbol { B }}$. $g d h A$ and $g d h B$ were cloned by $P C R$, using $P f u$ DNA polymerase (Stratagene). Primers gdhAEco1 5'-TGTGAATTCATTGTAAACACTTGGTGTAAACGG-3' (nt 1306-1337) and gdhAEco2 5'-CGTAGAATTCAAATGCTTTAGAAAGGCCC-3' (nt 3806-3774), and template plasmid pUCD5723 were used to amplify a 2501 bp DNA fragment containing gdhA. Primers gdhBEco1 5'-GAAGCGAAT'TCCCCACTCGGAACATA-3' (nt 50-77) and gdhBEco2 5'-ATTCTGAATTCTGCCGCGAATCTATGG-3' (nt 2753-2730), and genomic DNA of 1056R were used to amplify a 2703 bp DNA fragment containing $g d h B$. The underlined nucleotides correspond to EcoRI restriction sites. The primers used allowed the amplification of the putative 
natural expression signals of each Gdh. The amplified fragments were cloned into the EcoRI site of pBluescript SKII $(-)$, leading to plasmids pUCD6712 and pUCD6715 containing the $g d h A$ and $g d h B$ genes, respectively.

The 54 bp DNA fragment containing the 11 bp inverted repeat upstream of $g d h A$ was amplified by PCR using Taq polymerase, plasmid pUCD5723 as the template and primers HR3 5'-AGCTCATTGTAAACACTGG-3' (nt 1305-1324) and HR4 5'-AAAGTAAAACAGAATACTTAGTG-3' (nt 13591337). The amplified 54 bp DNA fragment was cloned in both orientations into the EcoRV site of pBluescript SKII $(-)$ to yield plasmids pUCD5061 and pUCD5062.

RNA extraction and Northern blot hybridization analysis. RNA was isolated and purified from cells grown in MGY medium with or without $2 \%$ glucose during both exponential $(4.5 \mathrm{~h})$ and stationary phases (14 h) of growth (Pujic, 1997). RNA electrophoresis was performed in $0.8 \%$ SeaKem GTG agarose (FMC) in $10 \mathrm{mM}$ sodium phosphate, $\mathrm{pH} 7 \cdot 0,10 \mathrm{mM}$ sodium acetate. RNA was then transferred onto a Nytran $0 \cdot 2 \mu \mathrm{m}$ membrane (Schleicher \& Schuell). Hybridization was performed using primers gdhARNA 5'-GCTGATGAGTCGCCCTGAACAGA TTTG-3' and gdhBRNA 5'-TCTGAGGATCTGTTGCCGTATTAAAG- $3^{\prime}$ as probes to detect $g d h A$ and $g d h B$-specific-transcripts, respectively (Pujic et al., 1998). Probes were 5 '-end-labelled using T4 DNA kinase (Pharmacia) and $\left[\gamma^{32} \mathrm{P}\right] \mathrm{dATP}$ (DuPont-NEN Products).

\section{RESULTS}

\section{$P$. citrea contains a second $g d h$ gene}

CMC6, a nitrosoguanidine mutant unable to induce pink disease, can be complemented by a DNA fragment containing the $g d h A$ gene that encodes a Gdh protein

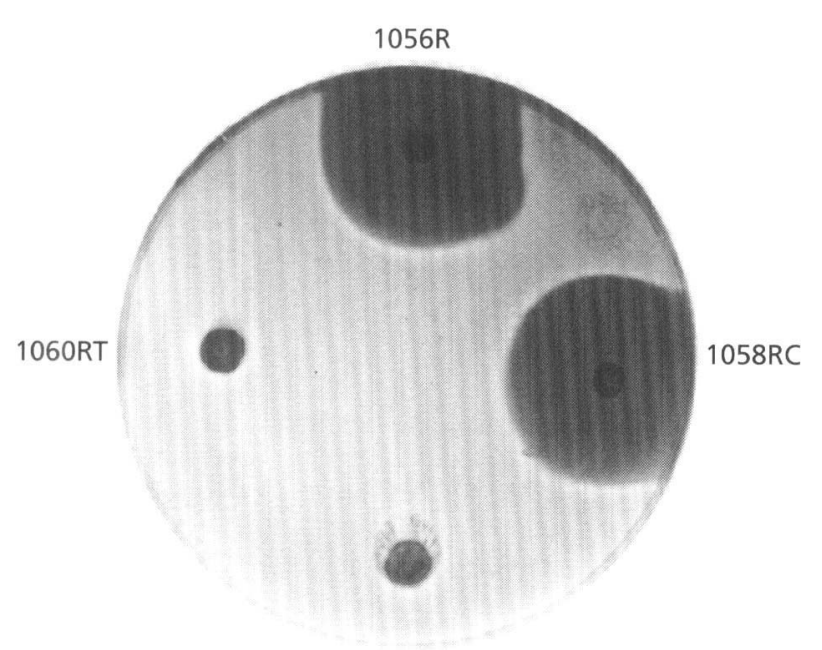

1061RCT

Fig. 1. In vivo Gdh activity detected on solid MGY medium supplemented with $2 \%$ glucose. After growth for 2 d at $30^{\circ} \mathrm{C}$, colonies were overlaid with $10 \mathrm{ml} 0.5 \%$ agar containing methylene blue $\left(65 \mu \mathrm{g} \mathrm{ml}^{-1}\right)$ and eosin yellow $\left(0.4 \mathrm{mg} \mathrm{ml}^{-1}\right)$. A dark (purple) halo around colonies indicates Gdh activity. 1056R, wild-type $P$. citrea; $1058 R C$, single mutant $\triangle$ gdhA::cat; 1060RT, single mutant gdhB::tet; 1061RCT, double mutant $\Delta g d h A::$ cat gdhB::tet.
(Cha et al., 1997a). This observation suggested that gdh $A$ had been inactivated in CMC6, in agreement with the finding that CMC6 was deficient for Gdh activity (Cha et al., 1997a). To verify that the gdh-deficient phenotype of CMC6 was due to the loss of $g d h A$ function, we constructed a strain in which the $g d h A$ gene was inactivated by insertion of a chloramphenicol resistance (cat) gene. This mutant strain (1058RC) was tested for Gdh activity in vivo using a plate assay in which the activity is detected by the formation of a halo around colonies grown in presence of glucose and methylene blue/eosin yellow. Unexpectedly, strain $1058 \mathrm{RC}$ was found to still possess the enzymic activity at wild-type levels (Fig. 1) and was still able to induce the pink coloration of pineapple juice, albeit with 10-15\% less colour intensity than that of the wild-type strain (Table 2). Furthermore, when the in vitro Gdh activity was measured in crude extracts, no significant reduction was observed compared to the wild-type strain. As shown in Table 2, the Gdh activity of the wild-type strain $1056 \mathrm{R}$ is low when cells are grown in MGY but increases eightfold when glucose is added to the growth medium. Similar basal and induced levels are detected with the $g d h A^{-}$strain $1058 \mathrm{RC}$. These results indicate that, under the conditions used here, $g d h A$ contributes only marginally to the total Gdh activity expressed by $P$. citrea and, hence, to pink disease. These results also suggest that (a) P. citrea 1056R contains at least another active gdh gene and (b) the mutation in strain CMC6 did not affect $g d h A$ itself. Instead, we hypothesized that the CMC6 mutation affected the other putative gdh gene(s) or their expression.

To verify this hypothesis, we first tried to identify and clone other $g d h$ genes in $P$. citrea. We selected conserved sequence motifs produced from the alignment of Gdhs from E. coli, A. calcoaceticus and G. oxydans to design the degenerate PCR primers pqq2 and pqq4, which were then used to amplify other potential $g d h$ loci as described in Methods. When the genomic DNA of strain 1058RC was used as template, a single, specific $1.4 \mathrm{~kb}$ DNA fragment was amplified. This DNA fragment was cloned in pBluescript SKII $(-)$, resulting in plasmid pUCD5063, and its nucleotide sequence was determined. The 1387 bp fragment was $73 \%$ similar at the nucleotide level to that of $g d h A$ (nt 881-2268). When used as a probe in Southern blot hybridization experiments, the amplified fragment hybridized to a specific $4.3 \mathrm{~kb}$ EcoRI-BamHI fragment derived from the genomic DNA of strain $1056 \mathrm{R}$, as opposed to the $3.3 \mathrm{~kb}$ EcoRI-BamHI fragment containing $g d h A$ (data not shown). $P$. citrea therefore contains a second $g d h$ gene.

This new putative $g d h$ gene was called $g d h B$ and was inactivated by the insertion of a tetracycline resistance (tet) cassette, as described in Methods, resulting in strain 1060RT. To clone the entire $g d h B$ gene, the genomic DNA of strain 1060RT was digested with EcoRI, ligated into the EcoRI site of pBluescript SKII(-) and transformed into $E$. coli DH5 $\alpha$ cells with selection for tetracycline resistance. Among the transformants, a plasmid containing a $9.5 \mathrm{~kb}$ DNA insert corresponded 
Table 2. Colour-forming and Gdh in vitro activities of $g d h A$ and gdh $B$ mutants

Colour-forming activity was measured at $420 \mathrm{~nm}$ after $3 \mathrm{~d}$ growth in pineapple juice. Gdh in vitro specific activities were measured after $10 \mathrm{~s}$ with crude extracts of cells grown for $3 \mathrm{~d}$ in MGY medium without $(-)$ or with $(+) 2 \%$ glucose. Gdh specific activity is expressed in pmol Wurster's Blue reduced ( $\mu$ g protein $)^{-1} \mathrm{~s}^{-1}$. Each value corresponds to the mean of three measurements $\pm \mathrm{sD}$.

\begin{tabular}{|llccc|}
\hline Strain & \multicolumn{1}{c}{ Genotype } & $\begin{array}{c}\text { Colour-forming } \\
\text { activity }(\%)\end{array}$ & \multicolumn{2}{c|}{ Gdh specific activity } \\
\cline { 4 - 5 } & & & - Glucose & + Glucose \\
\hline 1056R & Wild-type & 100 & $70 \pm 7$ & $562 \pm 13$ \\
1058RC & $\Delta g d h A::$ cat & $90 \pm 6$ & $68 \pm 7$ & $576 \pm 13$ \\
1060RT & gdhB::tet & $7 \pm 4$ & $73 \pm 5$ & $93 \pm 5$ \\
1061RCT & $\Delta g d h A::$ cat gdhB::tet & $1 \pm 1$ & $78 \pm 4$ & $70 \pm 7$ \\
\hline
\end{tabular}

to an EcoRI DNA fragment harbouring $g d h B$ inactivated by the tet cassette. This plasmid, designated pUCD6711, was used to determine the complete nucleotide sequence of $g d h B$.

\section{Sequence analysis of $g d h B$ and its corresponding product}

Sequence analysis of a $2767 \mathrm{bp}$ fragment from pUCD6711 revealed an ORF of 2370 nt (nt 263-2633) that would encode a putative GdhB protein of 790 aa with a predicted molecular mass of $85.6 \mathrm{kDa}$. Its amino acid sequence is $75 \%$ similar to that of GdhA and 72,63 and $62 \%$ similar to Gdhs of E. coli, A. calcoaceticus and G. oxydans, respectively. A putative PQQ-binding site is located near the C terminus of GdhB (nt 2444-2578). The hydrophobic profile of GdhB, determined by the method of Kyte \& Doolittle (1982), showed four potential membrane-spanning domains near the $\mathrm{N}$ terminus (nt 284-424, 440-490, 510-574 and 611-667), suggesting that GdhB might be anchored to the cytoplasmic membrane. The $g d h B$ gene is preceded by a putative -10 box (TATAAA) $30 \mathrm{nt}$ upstream of the ORF (nt 233-238) but no consensus sequence for a -35 box could be detected. Two 12 bp inverted repeats (IR) are also located immediately upstream of $g d h B$ (IR1, nt 96-123, and IR2, nt 111-151). These IRs show no significant homology with sequences deposited in the databases but may be involved in the transcriptional/ translational regulation of $g d h B$. Finally, $g d h B$ is followed by a potential $\rho$-independent transcriptional terminator 58 bases downstream of the translational stop codon (nt 2694-2729).

\section{GdhB is functional in vivo and in vitro, and is mainly responsible for pink colour formation}

To determine if GdhB is functional in P. citrea and to study its involvement in pink disease, we compared the properties of strain 1060RT ( $g d h B:: t e t$ ) with that of the wild-type strain 1056R. Each strain was tested for in vivo Gdh activity and for its ability to colour pineapple juice. As shown in Fig. 1, no halo typifying Gdh activity was produced by $1060 \mathrm{RT}$, while the wild-type strain
1056R produced a profuse halo. Accordingly, 1060RT was unable to colour pineapple juice significantly (Table 2 ). Under the conditions tested here, it appears that $g d h B$ is functional in vivo and is contributing to most of the Gdh activity, which results in the intense coloration of pineapple juice. To confirm this, we measured the Gdh activity associated with the mutant and wild-type strains in vitro. As shown in Table 2, inactivation of gdhB alone (1060RT) results in $90 \%$ loss of Gdh activity when cells are grown in presence of glucose. It is worth noting that the double mutant strain (1061RCT), which is not impaired in its growing abilities in pineapple juice or LB medium, shows virtually no Gdh activity (a nonspecific background of $12 \%$ is observed), demonstrating that (a) $g d h A$ contributes in a minor way to the overall cellular Gdh activity (Table 2 ) and (b) P. citrea probably contains only two active Gdhs.

\section{gdhB expression is induced by glucose in stationary phase}

The data presented in Table 2 suggest that the expression of $g d h B$ is induced by glucose. The measurement of the transcription of $g d h B$ would verify this prediction. Total RNA of $1056 \mathrm{R}$ cells grown in MGY medium with or without glucose $(2 \%)$ was extracted during exponential and stationary phases of growth and examined by Northern blot hybridization analyses. As shown in Fig. 2(a), a specific transcript corresponding to $g d h B$ was observed in all cases. The size of this transcript ( $2.4 \mathrm{~kb}$ ) is in good agreement with an initiation occurring at the promoter region upstream of $g d b B$ and termination occurring at the $\rho$-independent terminator located downstream of the coding sequence. Quantitative estimates of Fig. 2(a) show that the amount of $g d h B$ mRNA is two to threefold higher in cells during the exponential phase of growth $(4.5 \mathrm{~h})$ than in cells in stationary phase $(14 \mathrm{~h})$. However, while no significant difference in the amount of $g d h B$ transcripts is detected upon addition of glucose during the exponential phase, a three to fourfold stimulation of $g d h B$ transcription is observed during stationary phase (Fig. 2a). These results corroborate the in vitro measurements of Gdh activity, which, to mimic conditions used for pink assays, are 

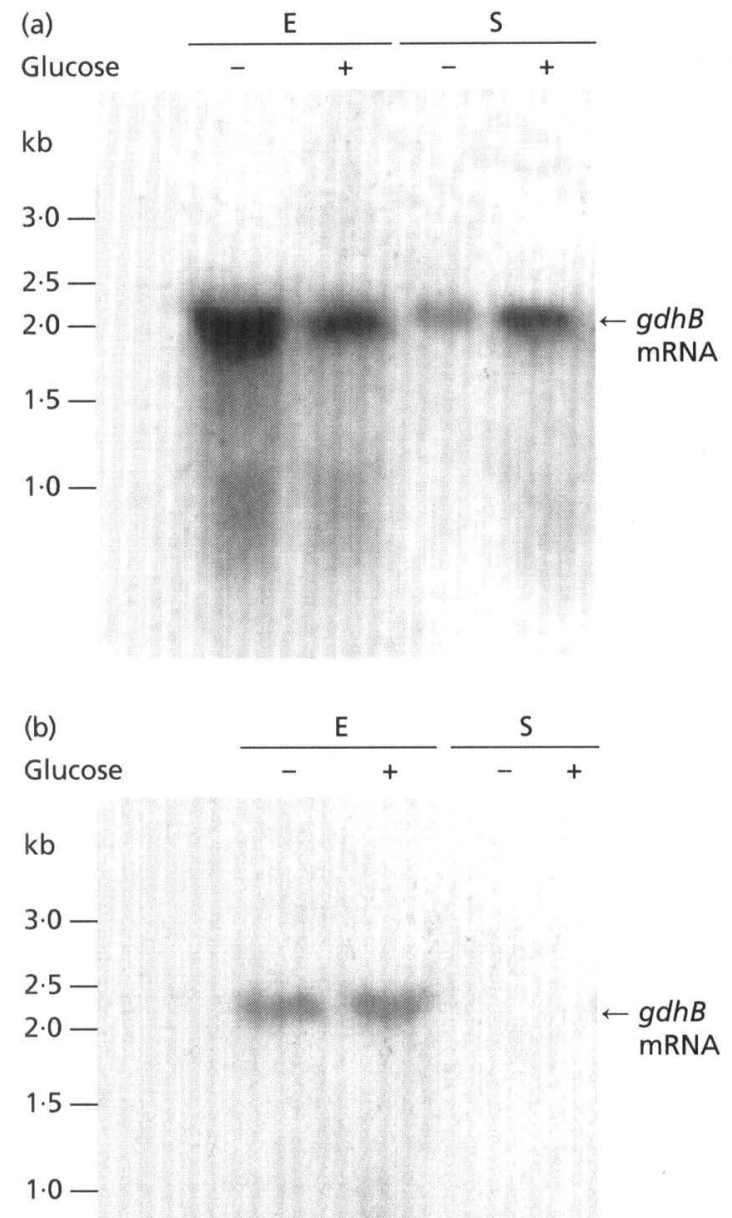

Fig. 2. Transcript analysis of gdhB in wild-type strain 1056R (a) and strain CMC6 (b). Total RNAs ( $30 \mu \mathrm{g}$ per lane) from cells grown in MGY medium without $(-)$ or with $(+) 2 \%$ glucose during exponential (E) or stationary phase (S). The size marker used was the RNA Millenium Marker (Ambion).

performed well inside the stationary phase of growth. They also indicate that expression of $g d h B$ is likely to be under growth-phase-dependent regulation. Under similar conditions, $g d h A$ mRNA transcript levels remained undetectable (see below).

\section{The mutation in strain CMC6 affects gdhB transcription during stationary phase}

Strain CMC6 is deficient in Gdh activity and is unable to produce the pink colour (Cha et al., 1997a). Since pink disease requires $g d h B$, a mutation affecting this gene might be expected to be present in the mutant strain. To monitor the status of this gene, we analysed the transcription of $g d h B$ in strain CMC6 by Northern blot hybridization. As shown in Fig. 2(b), gdhB transcripts were produced abundantly during the exponential phase

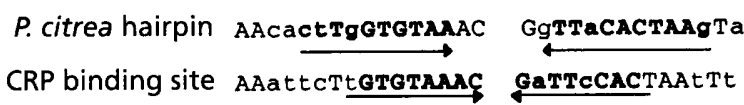

Fig. 3. Sequence comparison between the $11 \mathrm{bp}$ IR upstream gdhA and the CRP-binding site in the $E$. coli galactose operon. IRs are indicated by arrows and nucleotides in bold letters. Identical nucleotides are shown in capital letters.

of growth. However, in sharp contrast to the wild-type strain, no $g d h B$-specific mRNA was detected during the stationary phase of growth (Fig. 2b). These results indicate that strain CMC6 is affected in the stationaryphase-specific expression of $g d h B$. This behaviour could be explained by a mutation affecting the promoter region of $g d h B$, where potential regulatory proteins are expected to bind. However, sequencing of a region of 500 bp located immediately upstream of the GdhB ORF did not reveal any mutation in strain CMC6 (data not shown).

\section{Strain CMC6 can be complemented by a non-coding DNA sequence located upstream of gdhA}

In a previous study, plasmid pUCD5723, which carries a $3.9 \mathrm{~kb}$ genomic DNA fragment that includes $g d h A$, was identified by its ability to complement the mutation in strain CMC6 (Cha et al., 1997a). This complementation could be due either to the overexpression of GdhA in a way that would compensate for the lack of GdhB or to other DNA sequences present in this fragment. To investigate if the former possibility fully accounts for the complementation, we cloned a $2.5 \mathrm{~kb}$ fragment containing only the $g d h A$ gene with its promoter region (nt 1301-3802) into pBluescript SKII(-) (plasmid pUCD6712) and measured the level of expression afforded by this construct in the Gdh-deficient double mutant strain 1061RCT. As expected, pUCD6712 restored the ability of strain 1061RCT to produce haloes on MGY plates containing glucose and methylene blue/eosin yellow, but only to one-third of their normal size. In the same assay, $g d h B$ cloned into pBluescript SKII (-) (plasmid pUCD6715) fully restored the ability of strain 1061RCT to produce haloes (data not shown). These results indicate that overexpression of GdhA might only partially account for the complementation of strain CMC6 by pUCD5723. We therefore decided to search for sequences in the $3.9 \mathrm{~kb}$ genomic fragment that could promote complementation independently of GdhA. For this, we created plasmid pUCD5020 by deleting a $1750 \mathrm{bp}$ DNA fragment internal to gdhA. To our surprise, pUCD5020 was still able to complement strain $\mathrm{CMC} 6$ as judged by the production of haloes and by the coloration of pineapple juice (data not shown). Thus, the original $3.9 \mathrm{~kb}$ DNA fragment contained additional sequences responsible for complementation, besides $g d h A$. Convenient restriction enzyme sites reduced the size of the complementing DNA to a $1010 \mathrm{bp}$ BglII-NcoI fragment located upstream of $g d h A$ (pUCD5027). Strain CMC6 containing pUCD5027 was 
Table 3. Complementation of strain CMC6

Colour-forming and Gdh in vitro activities were measured as described in the legend to Table 2 in MGY $+2 \%$ glucose. Gdh specific activity is expressed in pmol Wurster's Blue reduced ( $\mu \mathrm{g}$ protein $)^{-1} \mathrm{~s}^{-1}$. Each value corresponds to the mean of three measurements $\pm \mathrm{SD}$.

\begin{tabular}{|llcc|}
\hline Strain & \multicolumn{1}{c}{ Plasmid } & $\begin{array}{c}\text { Colour-forming } \\
\text { activity }(\%)\end{array}$ & $\begin{array}{c}\text { Gdh specific } \\
\text { activity }\end{array}$ \\
\hline 1056R & None & 100 & $562 \pm 13$ \\
CMC6 & None & $6 \pm 1$ & $45 \pm 2$ \\
CMC6 & pBluescript SKII - - & $14 \pm 2$ & $149 \pm 3$ \\
CMC6 & pUCD5061 & $68 \pm 7$ & $181 \pm 3$ \\
CMC6 & pUCD5062 & $63 \pm 7$ & $125 \pm 5$ \\
\hline
\end{tabular}

able to colour pineapple juice to $55-60 \%$ of the wildtype level (data not shown). To further reduce the size of the complementing DNA fragment, the $1010 \mathrm{bp}$ fragment was subjected to exonuclease III and S1 nuclease digestion. The complementing sequence is located within a $36 \mathrm{bp}$ fragment and contains an $11 \mathrm{bp}$ IR located $38 \mathrm{bp}$ upstream of the gdhA start codon. Interestingly, this $11 \mathrm{bp}$ IR is homologous to sequences which bind the cAMP receptor protein (CRP) of the galactose operon of E. coli (Musso et al., 1977) (Fig. 3), suggesting that a CRP homologue may be operating as a $g d h A$ control in P. citrea. No significant homology was found between this $11 \mathrm{bp} \mathrm{IR}$ and the two IRs located upstream of $g d h B$.

To verify that the $11 \mathrm{bp}$ IR was responsible for the complementation of strain CMC6, a 54 bp DNA fragment containing this IR was amplified by PCR and cloned into the EcoRV site of pBluescript SKII $(-)$. Both orientations of the insert were obtained, resulting in plasmids pUCD5061 and pUCD5062. These plasmids were tested for their ability to restore the pink colour activity and Gdh activity of CMC6 in vivo and in vitro. As shown by their ability to produce a halo on MGY plates containing glucose and methylene blue/eosin yellow, both plasmids restored the ability of strain CMC6 to oxidize glucose in vivo (data not shown). Additionally, both pUCD5061 and pUCD5062 complemented strain CMC6 for Gdh and colour-forming activities (Table 3). The intensity of the colour was $63-68 \%$ of that produced by the wild-type strain and in vitro Gdh activity was $22-32 \%$ of that of the wild-type level (Table 3). It therefore appears that the initial complementation of CMC6 by pUCD5723 was due to the cumulative effects of GdhA overexpression and the action of the $11 \mathrm{bp} \mathrm{IR}$.

\section{The CRP-like operator restores transcription of gdhA in strain CMC6}

To understand further the complementation of strain CMC6 by the $11 \mathrm{bp}$ IR, we decided to analyse the transcription of $g d h A$ and $g d h B$ in strain CMC6

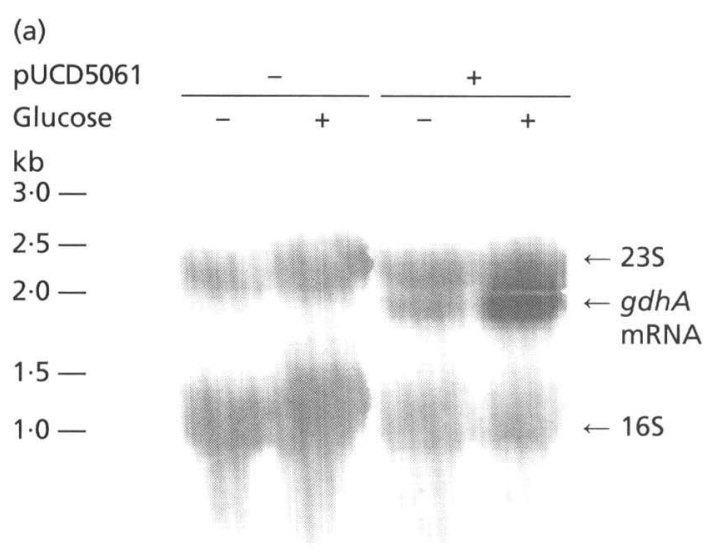

(b)

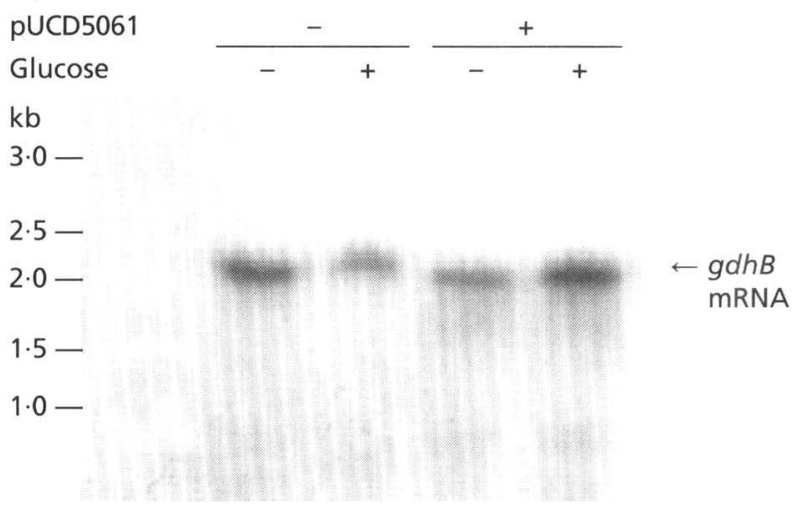

Fig. 4. Transcript analysis of $g d h A$ (a) and $g d h B$ (b) in strain CMC6 in the absence $(-)$ or presence $(+)$ of pUCD5061. Total RNAs $(30 \mu \mathrm{g}$ per lane) from cells grown in MGY medium without $(-)$ or with $(+) 2 \%$ glucose during exponential phase. The size marker used was the RNA Millenium Marker (Ambion).

containing pUCD5061 by Northern blot hybridization. In $P$. citrea harbouring only two active Gdhs, complementation can be due to restoration of either $g d h A$ or $g d h B$ expression (or both). Results showed that, while no gdhA-specific mRNAs were detected in CMC6, transcripts corresponding to $g d h A$ were detected during exponential growth in the presence of pUCD5061 (Fig. $4 a) . g d h B$ transcripts were still present irrespective of the presence or the absence of pUCD5061 during exponential phase (Fig. 4b). Despite several attempts, we were unable to obtain mRNAs from strain CMC6 containing pUCD5061 during the stationary phase of growth. CMC6 cells containing pUCD5061 grew more slowly in exponential phase in the presence of glucose than CMC6 cells without the plasmid. This analysis therefore suggests that the $54 \mathrm{bp}$ DNA fragment containing the putative operator allows expression of $g d h A$, probably by titrating away a putative negative regulator. In agreement with this, we found that complementation of the CMC6 phenotype was strictly dependent on the presence of a functional $g d h A$ gene and was independent of the presence of $g d h B$ : a $g d h A^{-}$mutant of CMC6 (1062RC) was not complemented by pUCD5061 while a 
$g d h B^{-}$mutant (1063RT) containing this plasmid showed Gdh activity in vivo and was able to generate pink colour (data not shown).

\section{DISCUSSION}

$P$. citrea was found to possess two $g d h$ genes, whose products are involved in the formation of the dark colour associated with the pink disease of pineapple. The second gene, $g d b B$, encodes a 790 aa Gdh which is $75 \%$ similar to the previously described GdhA protein (Cha et al., 1997a). GdhB contains four hydrophobic regions at the $\mathrm{N}$ terminus, all or some of which might be potential membrane-spanning domains. In agreement with the presence of a putative PQQ-binding site, oxidation of glucose by $\mathrm{GdhB}$ requires PQQ as a cofactor. Indeed, complementation of an E. coli gdhdeficient strain by $g d b B$, when glucose is the sole carbon source, is only achieved if PQQ is present (data not shown). Moreover, PQQ seems to be endogenously synthesized in $P$. citrea, since in vivo and in vitro Gdh activities can be measured without adding exogenous PQQ in the reaction assays. In agreement with this, two independent chemical mutants, CMF46 and CMK8 (Cha et al., 1997b), which were unable to colour pineapple juice and to oxidize glucose in vivo, were restored in their ability to produce Gdh activity when PQQ was provided in the growth medium. Other cofactors such as NAD, NADP or NADPH could not substitute for PQQ in these experiments (data not shown). GdhB is mainly involved in the oxidation of glucose, since inactivation of $g d h B$ (mutant 1060RT) destroys the major Gdh activity both in vivo and in vitro and also decreases dramatically the pink-colour-forming activity of $P$. citrea. This demonstrates that $g d b B$ is required for pink disease and reinforces the notion that oxidation of glucose is the first step leading to colour formation. In agreement with this, the ability of $P$. citrea strains CMC6 and 1061RCT to colour pineapple juice is restored upon addition of gluconate, the product of oxidation of glucose (Cha et al., 1997a; C. Pujol \& C. Kado, unpublished).

Measurement of Gdh activity in crude extracts showed that GdhB activity is stimulated eightfold by the presence of glucose in the culture medium (Table 2). This induction by glucose was apparent during the stationary phase of growth and is in agreement with our finding that transcription of $g d h B$ is increased by a factor of 3-4 during stationary phase in the presence of glucose. These results suggest that $g d h B$ is under the control of glucose-inducible, stationary-phase-specific regulation.

Our results also show that $g d h A$, which was originally thought to be responsible for pink-colour-forming activity, only plays a minor role in disease development. GdhA is functional in vivo in $E$. coli and in $P$. citrea when carried on a high-copy-number vector. However, when compared to $g d b B$ carried on the same vector, GdhA activity was considerably lower. Complementation of strain 1061RCT ( $\left.g d h A^{-} g d h B^{-}\right)$with $g d h A$ only partially restored pink-colour-forming activity; however, when complemented with $g d h B$, this double mutant strain was restored to a level nearly equivalent to that of the wild-type strain (data not shown). Using two other assays, halo formation and in vitro measurement of Gdh activity, no detectable activity could be ascribed to $g d h A$ (Fig. 1, Table 2). This lack of activity can probably be attributed to the low expression of the gene rather than to an intrinsically low activity of the protein. No gdhA mRNA could be detected in Northern blot analyses under the conditions tested here. It is possible that, under circumstances when $g d h A$ is expressed, GdhA activity is more specific for certain sugars as has been shown with Gdhs from P. stutzeri (Cleton-Jansen et al., 1988), A. calcoaceticus (Cleton-Jansen et al., 1989) and G. oxydans (Cleton-Jansen et al., 1991). However, no Gdh activity could be detected in presence of fructose, sucrose, maltose, lactose or arabinose (data not shown). Even if GdhA is able to oxidize some other substrate, this process is not involved in the pink-colour-forming activity of $P$. citrea.

Our results show that strain $\mathrm{CMC6}$, isolated as being unable to induce pink colour formation (Cha et al., $1997 \mathrm{~b}$ ), is specifically affected in expression of $g d h B$ during the stationary phase of growth: no gdhB mRNA could be detected in Northern blot experiments after CMC6 cells entered stationary phase (Fig. 2b). Interestingly, the expression of $g d h B$ during the exponential phase of growth was not affected. This suggests that the expression of GdhB during exponential phase is not relevant to pink disease formation. Although the CMC6 mutation was not identified in this study, the results suggest it affects the stationary-phasespecific expression of $g d h B$. Since no mutation was found in the $500 \mathrm{bp}$ region upstream of $g d h B$ encompassing the putative regulatory region, we presently favour the hypothesis that CMC6 is affected in a specific regulator required for $g d h B$ expression. This notion has been recently reinforced by our isolation of two independent mutants showing identical phenotypes to CMC6, which are inactivated in genes encoding proteins showing homology to regulators of the XylS-AraC family (C. Pujol \& C. Kado, unpublished). However, we cannot completely rule out the possibility that $g d h B$ mRNAs are being rapidly degraded in CMC6 cells during stationary phase.

Strain CMC6 can be, at least partially, complemented by a 54 bp DNA fragment (pUCD5061) derived from the non-coding region upstream of $g d h A$. This $54 \mathrm{bp}$ element, which does not carry any mutation in strain CMC6 compared to the wild-type strain, restored $55-67 \%$ of the colour-forming activity of CMC6 cells when carried on a high-copy-number plasmid (Table 3). Interestingly, this fragment contains an $11 \mathrm{bp}$ inverted repeat homologous to that of the CRP-binding site in the gal operon of E. coli (Musso et al., 1977; Weickert \& Adhya, 1993), suggesting that it corresponds to a binding site for a repressor down-regulating $g d h A$ expression. We propose that the observed complementation of strain CMC6 by the 54 bp fragment cloned on a high-copynumber vector is due to the titration of this putative 
repressor by binding to this fragment and reducing its effective concentration, thus allowing expression of $g d h A$. This repressor titration hypothesis is supported by the fact that $g d h A$-specific mRNAs are produced during exponential phase in $\mathrm{CMC} 6$ cells containing the $54 \mathrm{bp}$ fragment, while the CMC6 strain produces no gdhA mRNA (Fig. 4a). Furthermore, complementation of strain CMC6 by the $54 \mathrm{bp}$ fragment requires a functional $g d h A$ gene but not a $g d h B$ gene (data not shown). No effect on pink coloration was observed when pUCD5061 was introduced into the wild-type strain (data not shown).

The presence of two $g d h$ genes, whose regulation remains to be further elucidated in $P$. citrea, reflects a redundant and complex mechanism for glucose utilization by this organism. Clearly, $g d h B$ appears to be the main locus involved in pink disease. Although the redundancy of $g d h$ genes is not unusual, their regulation based on both glucose concentration and growth phase in a reciprocal manner seems novel and reflects a highly evolved component of plant-microbe interaction.

\section{ACKNOWLEDGEMENTS}

We thank Dr Nora Goosen for kindly providing a $g d h$ deficient $E$. coli strain. We are very grateful to Frédéric Chédin for valuable discussions on the work. We also thank Brian Kelly, Ehr-Min Lai and Petar Pujic for critical comments on this manuscript. We appreciate Petar Pujic for sharing his experience in RNA preparation and Viet Pham for technical help. This study was sponsored by Dole Philippines Inc.

\section{REFERENCES}

Ameyama, M., Matsushita, K., Ohno, Y., Shinagawa, E. \& Adachi, O. (1981). Existence of a novel prosthetic group, PQQ, in membrane-bound electron transport chain-linked, primary dehydrogenases of oxidative bacteria. FEBS Lett 130, 179-183.

Birnboim, H. C. (1983). A rapid alkaline extraction method for the isolation of plasmid DNA. Methods Enzymol 100, 243-255.

Buchert, J. \& Viikari, L. (1988). Oxidative D-xylose metabolism of Gluconobacter oxydans. Appl Microbiol Biotechnol 29, 375-379.

Cha, J.-S., Pujol, C. J. \& Kado, C. I. (1997a). Identification and characterization of a Pantoea citrea gene encoding glucose dehydrogenase that is essential for causing Pink Disease of pineapple. Appl Environ Microbiol 63, 71-76.

Cha, J.-S., Pujol, C. J., Ducusin, A. R., Macion, E. A., Hubbard, C. H. \& Kado, C. I. (1997b). Studies on Pantoea citrea, the causal agent of Pink Disease of pineapple. J Phytopathol 145, 313-320.

Cleton-Jansen, A.-M., Goosen, N., Wenzel, T. J. \& van de Putte, P. (1988). Cloning of the gene encoding quinoprotein glucose dehydrogenase from Acinetobacter calcoaceticus: evidence for the presence of a second enzyme. J Bacteriol 170, 2121-2125.

Cleton-Jansen, A.-M., Goosen, N., Vink, K. \& van de Putte, P. (1989). Cloning, characterization and DNA sequencing of the gene encoding the $M_{r} 50000$ quinoprotein glucose dehydrogenase from Acinetobacter calcoaceticus. Mol Gen Genet 217, 430-436.

Cleton-Jansen, A.-M., Dekker, S., van de Putte, P. \& Goosen, N. (1991). A single amino acid substitution changes the substrate specificity of quinoprotein glucose dehydrogenase in Gluconobacter oxydans. Mol Gen Genet 229, 206-212.
Conway, T. (1992). The Entner-Doudoroff pathway: history, physiology, and molecular biology. FEMS Microbiol Rev 103, $1-27$.

Dokter, P., Frank, J. \& Duine, J. A. (1986). Purification and characterization of quinoprotein glucose dehydrogenase from Acinetobacter calcoaceticus L. M. D. 79.41. Biochem J 239, 163-167.

Duine, J. A., Frank, J. \& Van Zeeland, J. K. (1979). Glucose dehydrogenase from Acinetobacter calcoaceticus. FEBS Lett 108, 443-446.

Fliege, R., Tong, S., Shibata, A., Nickerson, K. W. \& Conway, T. (1992). The Entner-Doudoroff pathway in Escherichia coli is induced for oxidative glucose metabolism via pyrroloquinoline quinone-dependent glucose dehydrogenase. Appl Environ Microbiol 58, 3826-3829.

Fraenkel, D. G. (1996). Glycolysis, 2nd edn. Washington, DC: American Society for Microbiology.

Hommes, R. J. W., Postma, P. W., Neijssel, O. M., Tempest, D. W., Dokter, P. \& Duine, J.A. (1984). Evidence of a quinoprotein glucose dehydrogenase apoenzyme in several strains of Escherichia coli. FEMS Microbiol Lett 24, 329-333.

Hommes, R. W., Herman, P. T., Postma, P. W., Tempest, D. W. \& Neijssel, O. M. (1989). The separate roles of PQQ and apoenzyme syntheses in the regulation of glucose dehydrogenase activity in Klebsiella pneumoniae NCTC 418. Arch Microbiol 151, 257-260.

Kageyama, B., Nakae, M., Yagi, S. \& Sonoyama, T. (1992). Pantoea punctata sp. nov., Pantoea citrea sp. nov., and Pantoea terrea sp. nov. isolated from fruit and soil samples. Int J Syst Bacteriol 42, 203-210.

Kyte, J. \& Doolittle, R. F. (1982). A simple method for displaying the hydropathic character of a protein. J Mol Biol 157, 105-132.

Liu, S.-T., Lee, L.-Y., Tai, C.-Y., Hung, C.-H., Chang, Y.-S., Wolfram, J. H., Rogers, R. \& Goldstein, A. H. (1992). Cloning of an Erwinia berbicola gene necessary for gluconic acid production and enhanced mineral phosphate solubilization in Escherichia coli HB101: nucleotide sequence and probable involvement in biosynthesis of the coenzyme pyrroloquinoline quinone. $J$ Bacteriol 174, 5814-5819.

Matsushita, K., Shinagawa, E. \& Ameyama, M. (1982). DGluconate dehydrogenase from bacteria, membrane-bound. Methods Enzymol 89, 187-193.

Musso, R., Di Lauro, R., Rosenberg, M. \& de Crombrugghe, B. (1977). Nucleotide sequence of the operator-promoter region of the galactose operon of Escherichia coli. Proc Natl Acad Sci USA 74, 106-110.

Neijssel, O. M., Tempest, D. W., Postma, P. W., Duine, J. A. \& Frank, J. (1983). Glucose metabolism by $\mathrm{K}^{+}$-limited Klebsiella aerogenes: evidence for the involvement of a quinoprotein glucose dehydrogenase. FEMS Microbiol Lett 20, 35-39.

Pujic, P. (1997). Étude systematique du chromosome de Bacillus subtilis. PhD thesis, Université de Paris VII.

Pujic, P., Dervyn, R., Sorokin, A. \& Ehrlich, S. D. (1998). The $k d g R K A T$ operon of Bacillus subtilis: detection of the transcript and regulation by the $k d g R$ and $c c p A$ genes. Microbiology 144, 3111-3118.

Pujol, C. J. \& Kado, C. I. (1998). Characterization of pUCD 5000 involved in pink disease color formation by Pantoea citrea. Plasmid 40, 169-173.

te Riele, H., Michel, B. \& Ehrlich, S. D. (1986). Single-stranded plasmid DNA in Bacillus subtilis and Staphylococcus aureus. Proc Natl Acad Sci USA 83, 2541-2545. 
Rohrbach, K. G. (1989). Unusual tropical fruit diseases with extended latent periods. Plant Dis 73, 607-609.

Sambrook, J., Fritsch, E. F. \& Maniatis, T. (1989). Molecular Cloning: a Laboratory Manual, 2nd edn. Cold Spring Harbor, NY: Cold Spring Harbor Laboratory.

Sanger, F., Nicklen, S. \& Coulson, A. R. (1977). DNA sequencing with chain-terminating inhibitors. Proc Natl Acad Sci USA 74, 5463-5467.

Shinagawa, E., Matsushita, K., Adachi, O. \& Ameyama, M. (1984). D-Gluconate dehydrogenase, 2-keto-D-gluconate yielding, from Gluconobacter dioxyacetonicus: purification and characterization. Agric Biol Chem 48, 1517-1522.

Simon, R., Priefer, U. \& Puhler, A. (1983). A broad host range mobilization system for in vitro engineering: transposon mutagenesis in Gram-negative bacteria. Bio/Technology 1, 742-791.

Sonoyama, T., Yagi, S. \& Kageyama, B. (1988). Facultatively anaerobic bacteria showing high productivities of 2,5-diketo-Dgluconate from D-glucose. Agric Biol Chem 52, 667-674.

Van Schie, B. J., van Dijken, J. P. \& Kuenen, J. G. (1984). Non- coordinated synthesis of glucose dehydrogenase and its prosthetic group PQQ in Acinetobacter and Pseudomonas species. FEMS Microbiol Lett 24, 133-138.

Van Schie, B. J., Hellingwerf, K. J., van Dijken, J. P., Elferink, M. G. L., van Dijl, J. M., Kuenen, J. G. \& Konings, W. N. (1985). Energy transduction by electron transfer via a pyrrolo-quinoline quinone-dependent glucose dehydrogenase in Escherichia coli, Pseudomonas aeruginosa, and Acinetobacter calcoaceticus (var. lwoffii). J Bacteriol 163, 493-499.

Weickert, M. J. \& Adhya, S. (1993). The galactose regulon of Escherichia coli. Mol Microbiol 10, 245-251.

Yum, D. Y., Lee, Y. P. \& Pan, J. G. (1997). Cloning and expression of a gene cluster encoding three subunits of membrane-bound gluconate dehydrogenase from Erwinia cypripedii ATCC 29267 in Escherichia coli. J Bacteriol 179, 6566-6572.

Received 2 November 1998; revised 8 February 1999; accepted 15 February 1999. 


\title{
Effects of gene disruptions in the nisin gene cluster of Lactococcus lactis on nisin production and producer immunity
}

\author{
Runar Ra, ${ }^{1}$ Marke M. Beerthuyzen, ${ }^{2}$ Willem M. de Vos, ${ }^{2}$ Per E. J. Saris ${ }^{1}$ \\ and Oscar P. Kuipers ${ }^{2} \dagger$ \\ Author for correspondence: Oscar P. Kuipers. Tel: +3150 3632093. Fax: +31503632105. \\ e-mail: o.p.kuipers@biol.rug.nl
}

\footnotetext{
1 Department of Applied Chemistry and Microbiology, PO Box 56 00014 University of Helsinki, Finland

2 Microbial Ingredients Section, NIZO food research, PO Box 20, 6710 BA Ede, The Netherlands
}

\begin{abstract}
The lantibiotic nisin is produced by several strains of Lactococcus lactis subsp. lactis. The chromosomally located gene cluster nisABTCIPRKFEG is required for biosynthesis, development of immunity, and regulation of gene expression. Inframe deletions in the nisB and nisT genes, and disruption of nisC by plasmid integration, eliminated nisin production and resulted in a strongly reduced level of immunity of the strains. The transcription of two nisin operons was inactivated in these mutant strains, but could be restored by addition of small amounts of nisin to growing cultures. The immunity levels of the mutants were also raised by adding nisin to growing cultures, albeit not to wild-type level. A strain with an in-frame deletion in the nisl gene was still able to produce active nisin, but the production and immunity levels were markedly lower. By measuring immunity levels of the knock-out strains and determining mRNA levels, it is concluded that Nisl has an important function for nisin immunity and must cooperate with nisFEG-encoded proteins to provide a high level of immunity. Maximal immunity could not be obtained in the mutant strains, probably because the wild-type transcription levels from nisA and nisf promoters are not reached when essential nis genes are disrupted. Using Southern hybridization with a consensus promoter probe, no other DNA sequences similar to the nisA and nisF promoters could be detected, indicating that these two elements are probably the only ones in the chromosome regulated by nisin and are thus the only ones involved in the regulation of producer immunity.
\end{abstract}

Keywords: Lactococcus lactis, nisin, producer immunity, in-frame deletions

\section{INTRODUCTION}

The antimicrobial peptide nisin belongs to the family of lantibiotics and is produced by several strains of Lactococcus lactis (Hurst, 1981). It is used as a natural preservative in the food industry because it inhibits the growth of food-spoilage bacteria (Delves-Broughton et al., 1996). Nisin is ribosomally synthesized as a precursor peptide that undergoes post-translational modifications, i.e. dehydration of serine and threonine residues and formation of five intramolecular thioether ring structures called ( $\beta$-methyl)lanthionine residues (Gross $\&$ Morell, 1971). The eleven genes required for nisin

\footnotetext{
† Present address: RUG, PO Box 14, 9750 AA Haren, The Netherlands.
}

synthesis are located in a gene cluster on the nisinsucrose transposon Tn5276 (Buchman et al., 1988; Kaletta \& Entian, 1989; Steen et al., 1991; Rauch \& de Vos, 1992; Engelke et al., 1992; van der Meer et al., 1993; Kuipers et al., 1993; Engelke et al., 1994; Immonen et al., 1995; de Vos et al., 1995a, b; Siegers \& Entian, 1995). The organization of these genes is shown in Fig. 1. The nis $A$ gene encodes the 57 aa precursor peptide; $n i s B$ and nis $C$ probably encode membrane-associated proteins that are involved in the postranslational modification of nisin (Engelke et al., 1992; Kuipers et al., 1993; Siegers et al., 1996). nis T encodes a protein that shares significant homology with ATP-dependent translocator proteins, and recently it has been shown that Nis $\mathrm{T}$ is involved in the translocation of the fully modified precursor nisin across the cytoplasmic membrane (Qiao 


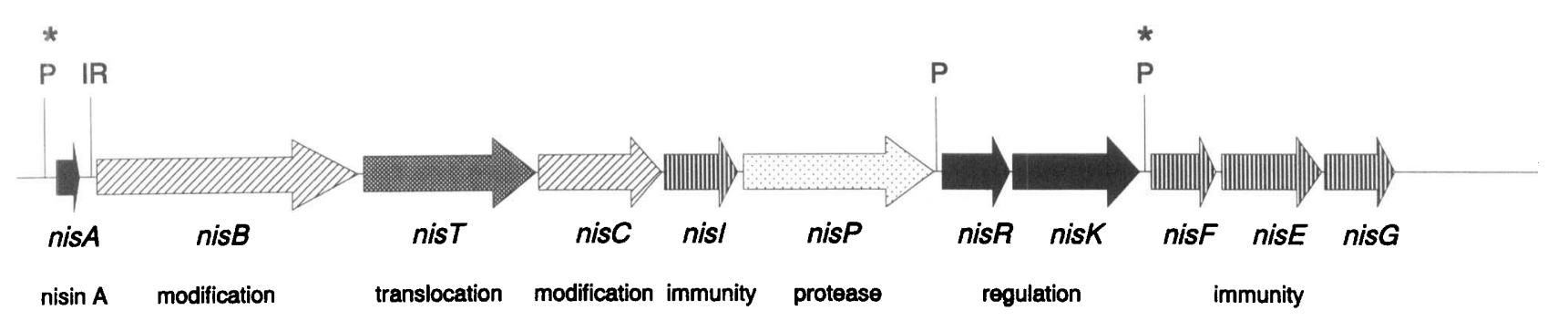

Fig. 1. Organization of nisin biosynthetic, regulatory and immunity genes. Regulated promoters are indicated by $P^{*}$ and constitutive promoters by P. An inverted repeat is indicated by IR.

\& Saris, 1996). nisI encodes a lipoprotein that is involved in immunity (Kuipers et al., 1993; Qiao et al., 1995) and nisFEG encode putative transporter proteins that probably, together with nisl, accomplish full nisin immunity of the producer strain (Siegers \& Entian, 1995; Dodd et al., 1996). nisP encodes an extracellular subtilisin-like protease involved in precursor processing (van der Meer et al., 1993;Qiao et al., 1996). nisR and nisK encode a response regulator (van der Meer et al., 1993) and a sensor of the histidine protein kinase family (de Vos et al., 1995a; Immonen et al., 1995; Siegers \& Entian, 1995), respectively, that belong to the class of twocomponent regulatory systems (Stock et al., 1990). It has been shown that both genes are involved in the regulation of nisin biosynthesis (van der Meer et al., 1993; Engelke et al., 1994). Recently, it has been demonstrated that fully modified nisin is the extracellular input signal for the sensor NisK (Kuipers et al., 1995). Small amounts of fully modified nisin can activate the transcription of its own structural gene, the transcription of the downstream genes, and transcription of nisFEG, via this two-component regulatory system (Kuipers et al., 1995; de Ruyter et al., 1996; Ra et al., 1996).

In this paper we describe disruptions in several genes of the nisin gene cluster, of which all except one were made in-frame to avoid polar effects on downstream genes. The effects of these disruptions on the transcription of nisin genes, nisin production and producer immunity were analysed. Remarkably, several levels of immunity could be distinguished in the knock-out strains relative to the wild-type strain, depending on the production levels of NisI and NisFEG, but the wild-type level could never be reached.

\section{METHODS}

Bacterial strains, plasmids and media. L. lactis strain NZ9700 (Kuipers et al., 1993) is a nisin A producing transconjugant, which was obtained from a mating between L. lactis MG1614 (Gasson, 1983) and the nisin A producer L. lactis NIZO R5 (Rauch \& de Vos, 1992). NZ9800 is a derivative of NZ9700, with a 4 bp deletion in the pronisin-encoding part of the nis $A$ gene, which is unable to produce nisin (Kuipers et al., 1993). L. lactis strains were grown in M17 broth (Difco) supplemented with $0.5 \%(\mathrm{w} / \mathrm{v})$ glucose or sucrose at $30^{\circ} \mathrm{C}$ without aeration Escherichia coli strain MC1061 (Casadaban et al., 1980) was used as a host strain for cloning experiments; it was grown in Tryptone Yeast (TY) medium (Sambrook et al., 1989) at $37^{\circ} \mathrm{C}$. Antibiotics were used in the following concentrations: ampicillin, $50 \mu \mathrm{g} \mathrm{ml}^{-1}$; erythromycin, $2.5 \mu \mathrm{g} \mathrm{ml}^{-1}$; chloramphenicol, $10 \mu \mathrm{g} \mathrm{ml}^{-1}$.

Construction of plasmids. The construction of the integrative plasmid pNZ9135, used for the disruption of the nisB gene by gene replacement, has been described previously (Kuipers et al., 1995). The gene replacement results in a $\Delta n i s B$ gene, in which the codons for amino acid residues 474-535 were specifically deleted. To construct the integrative plasmid pNZ9143 for disruption of the nisT gene, a $3.9 \mathrm{~kb}$ Sst $\mathrm{I}-\mathrm{Accl}$ fragment containing the nis $T$ gene and flanking regions was cloned into a SstI/AccI-digested pUC19 vector, which had an additional erythromycin resistance marker. The nis $T$ gene was changed by introducing a $231 \mathrm{bp}$ in-frame deletion in the middle of the gene; this was accomplished by removing an internal SpeI fragment, resulting in the removal of the codons for amino acid residues 318-395. To construct the singlecrossover integrative plasmid pNZ9134 (AnisC), an internal 753 bp NdeI-Ncol (filled in with Klenow) fragment of nis $C$ was cloned into a NdeI/Smal-digested pUC19 vector, which had an additional erythromycin resistance marker from pE194 (Leenhouts et al., 1991). To construct the integrative plasmid pNZ9147, a $4.7 \mathrm{kbp}$ SpeI-BclI fragment containing the nisI gene and flanking regions was cloned into a $\mathrm{XbaI} / \mathrm{BamHI}-$ digested pUC19 vector, which had an additional erythromycin resistance marker. The nisl gene was almost completely removed by introducing a $399 \mathrm{bp}$ in-frame deletion, resulting in removal of the codons for amino acid residues 57-190 of NisI. This was accomplished by removing an internal HpaI (partial digest)-AvaI (filled in with Klenow) fragment from the gene.

DNA, RNA and protein techniques. Plasmid and chromosomal DNA of L. lactis were isolated as described previously (Vos et al., 1989). L. lactis cells were transformed by electroporation (Holo \& Nes, 1989). Plasmid isolations from E. coli cells, and transformations of $E$. coli strains, were carried out according to established procedures (Sambrook et al., 1989). Restriction enzymes, T4 DNA ligase and other DNA-modifying enzymes were purchased from Gibco-BRL Life Technologies, New England Biolabs, Pharmacia or Promega and used as recommended by the manufacturers. Cloning procedures, radiolabelling of DNA fragments, agarose-gel electrophoresis and Southern blot hybridizations were carried out according to established procedures (Sambrook et al., 1989). PCRs were performed using the conditions described before (Kuipers et 
Table 1. Primers used in this study

\begin{tabular}{|lll|}
\hline Primer & \multicolumn{1}{c|}{ Sequence } & \multicolumn{1}{c|}{ Location } \\
\hline 1 & 5'-GAGTCCGAACCGAGTAC-3' & nisB \\
2 & 5'-GAGTTGAAATGTCTCGTG-3' & nisB \\
3 & 5'-GGAACATGGAACATTGGG-3' & nisT \\
4 & 5'-CATATGTTGAAAGTTTGCTAAC-3' $^{\prime}$ & nisC \\
5 & 5'-GAGAAGATATTTAATACTTATTGTGG-3' & nisI \\
6 & 5'-ATGCTTCAGTAAGAGATTTTCCTC-3' & nisI \\
7 & 5'-GTTTTGATGCGTCGCAACTTCATAG-3' & nisR \\
NIS121 & 5'-CTGAITAIATTCTGAAITTGTT-3' & Promoter fragment of \\
& & nisA and nisF \\
\hline
\end{tabular}

al., 1991). DNA sequencing was performed by the dideoxynucleotide chain-termination method (Sanger et al., 1977). Oligonucleotides, used as primers in sequencing reactions and for PCR, were purchased from Pharmacia. Primers used in this study are listed in Table 1. RNA isolation, Northern blotting and subsequent hybridization with radiolabelled probes were performed as described previously (Ra et al., 1995, 1996). The methods for nisin immunity assays for L. lactis (Kuipers et al., 1993) and nisin induction experiments (Kuipers et al., 1995) have also been described before. Pre-induction was performed by adding nisin $\mathrm{A}\left(0 \cdot 01 \mu \mathrm{g} \mathrm{m}^{-1}\right)$ to the freshly diluted culture. The nisin produced was quantified using an agar diffusion test with Micrococcus luteus as indicator. Dilution series of the samples were assayed in order to determine the minimal inhibitory concentration (MIC). This MIC value was used to compare percentage differences, which gives a more reliable estimation than values based on arithmetic measures of diffusion of nisin through agar. Western analyses were done with the KH1422 NisI-specific antiserum as described previously (Qiao et al., 1995).

Introduction of in-frame deletions in chromosomal nisin genes by gene replacement. The plasmids pNZ9135 ( $\triangle$ nisB), pNZ9143 ( $\Delta$ nis $T)$ and pNZ9147 ( $\Delta n i s I)$, all pUC19 derivatives that cannot replicate in $L$. lactis, were used to transform the nisin A producing L. lactis NZ9700. Erythromycin-resistant $\left(\mathrm{Em}^{r}\right)$ colonies were obtained that were the result of the integration of the plasmid caused by a recombination event involving one of the flanking regions on the plasmid and the corresponding regions on the chromosome. After subculturing for 100-200 generations in the absence of erythromycin, Em colonies were obtained as a result of a second recombination event with the flanking region on the other side of the disrupted region relative to the first recombination event. The expected disruptions in the chromosomal genes were confirmed by PCR analysis, Southern analysis and sequence analysis.

\section{RESULTS}

\section{In-frame deletions in nisB, nisT and nisl and single- crossover disruption of nisC}

After electroporation of NZ9700 with pNZ9135 to disrupt the nisB gene, one of several $\mathrm{Em}^{\mathrm{r}}$ colonies with the plasmid integrated in the correct location of the chromosome as judged by Southern analysis was grown without erythromycin. After plating, several $\mathrm{Em}^{\mathrm{s}}$ colonies were obtained in which a second recombination event had occurred resulting in excision of the plasmid from the chromosome. Southern blot hybridization, PCR analysis with primers 1 and 2 (Table 1) and sequence analysis confirmed the expected in-frame disruption of the nis $B$ gene on the chromosome in one of the colonies. The resulting strain was named NZ9735. Using a similar approach with other integrative plasmids, in-frame deletions were also obtained in nis $T$ (NZ9743) and nisI (NZ9747). Attempts to obtain a double-crossover integration to disrupt the nis $C$ gene on the chromosome of L. lactis NZ9700 were unsuccessful. After changing the strategy to obtain single-crossover integrants, Southern blot analysis of a picked $\mathrm{Em}^{\mathrm{r}}$ colony revealed that four copies of pNZ9134 had integrated in the same spot of the nis $C$ gene on the chromosome. The integrated plasmids could not be excised by culturing without erythromycin.

\section{Effects of in-frame deletions and plasmid integration on nisin production and immunity}

The effects of the various gene disruptions in the nisin gene cluster on nisin production were studied. Supernatants of overnight cultures were tested in a bioassay, and TCA-precipitated supernatants were analysed by SDS-PAGE for the production of nisin or nisin precursor (Table 2). Nisin production was blocked in all cases with one exception, i.e. strain NZ9747, carrying the inframe deletion in the nisI gene, which was still able to produce nisin, although the production level was reduced to approximately $20-40 \%$ of that of the wildtype NZ9700. This confirms that intact nisB, nisC and nis $T$ genes are essential for the production of active nisin in the supernatant and shows for the first time that intact nisI is not essential.

A disruption in the nisI gene resulted in an immunity level that was still approximately $10-30 \%$ of the maximum immunity level of the wild-type nisin-producing strain. Disruptions in nisB, nis $T$ and nis $C$ resulted in very low immunity levels, comparable to the immunity level of the $\triangle$ nis A strain NZ9800 (Kuipers et al., 1993), which is more than 100 times lower than that of the wild-type nisin producer NZ9700, but still much higher than that of strain MG1614, carrying no nisin 
Table 2. Effects of gene disruptions on nisin production, immunity and transcription of nisFEG

The amount of nisin used for pre-induction of the cultures was $0.01 \mu \mathrm{g} \mathrm{ml}^{-1}$. Nisin production levels:,$+++ 100 \% ;++, 20-40 \%$; - , no production. Immunity levels:,$++++ 100 \% ;+++30-60 \% ;++, 10-30 \%,+, 5-10 \%,-,<1 \%$. nisFEG transcript levels:,$++++ 100 \% ;+++, 50-70 \% ;++, 10-30 \%,-,<1 \%$.

\begin{tabular}{|c|c|c|c|c|c|}
\hline \multirow[t]{2}{*}{ Strain } & \multirow{2}{*}{$\begin{array}{l}\text { Extracellular } \\
\text { nisin production }\end{array}$} & \multicolumn{2}{|c|}{ Immunity } & \multicolumn{2}{|c|}{ Transcription of $n i s F E G$} \\
\hline & & $\begin{array}{l}\text { No } \\
\text { induction }\end{array}$ & $\begin{array}{l}\text { Pre-induction } \\
\text { with nisin }\end{array}$ & $\begin{array}{c}\text { No } \\
\text { induction }\end{array}$ & $\begin{array}{l}\text { Pre-induction } \\
\text { with nisin }\end{array}$ \\
\hline MG1614 & - & - & - & - & - \\
\hline NZ9700 & +++ & ++++ & $++t$ & ++++ & ++++ \\
\hline NZ9800 $\Delta$ nisA & - & - & ++ & - & ++ \\
\hline NZ9735 $\Delta$ nisB & - & - & ++ & - & ++ \\
\hline NZ9743 $\Delta$ nis T & - & - & ++ & - & ++ \\
\hline NZ9734 $\Delta$ nisC & - & - & + & - & ++ \\
\hline NZ9747 $\Delta n i s I$ & ++ & ++ & ++ & +++ & +++ \\
\hline
\end{tabular}

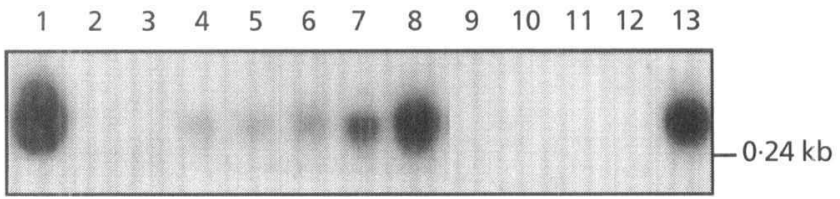

Fig. 2. Northern blot using total RNA from various $L$. lactis strains with the structural nisA gene as a probe. Lanes: 1, NZ9700; 2 and 3, MG1614; 4 and 9, NZ9800 ( $\Delta$ nisA); 5 and 10, NZ9735 ( $\Delta$ nisB); 6 and 11, 9743 ( $\Delta$ nis $T) ; 7$ and 12, NZ9734 $(\Delta$ nisC); 8 and 13, NZ9747 ( $\Delta$ nisl). The RNA in lanes 4-7 was isolated from cells that had been pre-induced with $0.01 \mu \mathrm{g}$ nisin A $\mathrm{ml}^{-1}$.

genes. However, when cells were pre-induced with $0.01 \mu \mathrm{g}$ nisin $\mathrm{A} \mathrm{ml}^{-1}$, the immunity levels were elevated to approximately $20 \%$ of the wild-type level (Table 2 ). Although no production of nisin was found in the extracellular medium after induction, it is possible that an intracellular, partly modified precursor nisin is

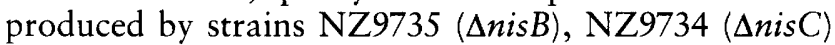
and NZ9743 $(\Delta n i s T)$. However, we were not able to detect any accumulation of intracellular nisin precursor with antibodies against the nisin leader peptide. The presence of a partly modified nisin precursor secreted by nisin-induced cells of strains NZ9735 or NZ9734 could also not be detected.

\section{Effects of gene disruptions and nisin induction on transcription of nisin immunity genes}

Strains NZ9735, NZ9743, NZ9734 and NZ9747, with disruptions in the nisB, nisT, nis $C$ and nisI genes, respectively, were checked for the presence of a nis $A$ and a nisFEG transcript by Northern hybridizations. In all cases, except in NZ9747, nis $A$ and nisFEG transcription was absent (Fig. 2, Table 2). Addition of nisin to the

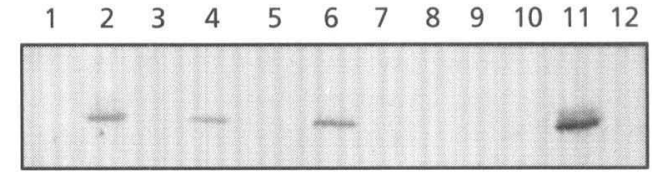

Fig. 3. Western blotting analysis of cells of L. lactis strains. A polyclonal Nisl-specific antiserum was used to recognize the Nisl protein. Lanes: 1 and 2, NZ9800 ( $\triangle$ nisA); 3 and 4, NZ9735 $(\Delta$ nisB); 5 and 6, NZ9743 ( $\Delta$ nisT); 7 and $8, N Z 9734$ ( $\Delta$ nisC); 9 and 10, NZ9747 ( $\Delta$ nisI); 11, NZ9700; 12, MG1614. The cells of the samples in lanes $2,4,6$ and 8 were pre-induced with $0.01 \mu \mathrm{g}$ nisin $\mathrm{A} \mathrm{ml}^{-1}$.

growing cultures restored the transcription of nis $A$ and nisFEG in all knock-out strains (Fig. 2, Table 2). In accordance with this, Western blotting analysis with NisI-specific antiserum showed that without induction, NisI is not produced in the mutant strains, whereas induced cells produce NisI, except strain NZ9747 ( $\Delta$ nisI) and strain NZ9734 (AnisC) (Fig. 3). In strain NZ9734 four plasmids had integrated into the nis $C$ gene and this is likely to hinder transcriptional readthrough of the nis $C$ to the nisI gene from the induced nis $A$ promoter. Interestingly, this strain was also less immune than the other knock-out strains, even after induction.

\section{Analysis of the number of promoters similar to the nis $A$ and nisF promoters}

In order to evaluate whether nisin induction could potentially initiate the transcription of genes other than nisABTCIPRKFEG, a Southern analysis was performed with EcoRI/EcoRV-digested chromosomal DNA of a nisin-producing strain using a degenerate oligonucleotide probe which hybridizes to the conserved regions of the two known nisin promoters. The expected size of the fragments with these promoters is 3 and 


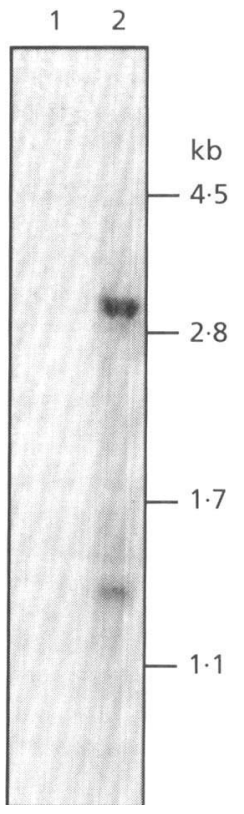

Fig. 4. Southern blot analysis of L. lactis strain MG1614, which does not contain the nisin operons (lane 1), and the nisinproducing strain NZ9700 (lane 2). A degenerate probe (NIS121) recognizing the homologous sequences of the nis $A$ and nis $F$ promoters was used.

$1 \cdot 3 \mathrm{~kb}$. The Southern blot result (Fig. 4) did not visualize any other bands than the expected ones, indicating that a nisin producer has no additional promoters in the chromosome with high homology to the nis $A$ or nisF promoters.

\section{DISCUSSION}

Gene disruptions with polar effects have previously been reported for the nis $A$, nis $B$, nis $T$, nis $C$, nisl, nisP, nisR, nisF and nisE genes (Kuipers et al., 1993; Siegers \& Entian, 1995; Siegers et al., 1996; Dodd et al., 1996; Ra et al., 1996; Qiao et al., 1996). However, correlating a phenotype to a specific locus using a mutant strain that contains a polar mutation, especially if the mutation is in a large operon like the biosynthetic operon expressed from the nis $A$ promoter, is not without risk. To avoid possible ambiguities, in-frame deletions were constructed in the nis $B$, nis $T$ and nisI genes. Attempts to obtain an in-frame deletion in the nis $C$ gene were unsuccessful and resulted in a strain with this gene disrupted by plasmid integration. Nisin production had ceased in the strains with the in-frame mutations in nis $B$ and nis $T$ and could not be restored by addition of subinhibitory amounts of nisin. Transcription of the genes downstream of the mutated nisB or nis $T$ genes was deduced to take place, because after nisin induction the product of the downstream nisl gene was detected in Western analysis using a NisI-specific antiserum. The fact that all nisin genes were transcribed after nisin induction and still no nisin was produced by the NZ9735 and NZ9743 strains conclusively demonstrates that NisB and Nis T are essential for the biosynthesis of nisin. The putative structure of NisT and the recent results of Siegers et al. (1996) and Qiao \& Saris (1996) suggest that NisT is involved in transport of precursor nisin and NisB in dehydration of the nisin precursor.

Analysis of the NZ9734 strain with the disrupted nisC gene showed that the plasmid insertion in nis $C$ resulted in polar effects as judged from the fact that that no NisI protein could be detected after nisin induction. Because no modified nisin precursor was secreted by strain NZ9734 upon nisin induction, as would be expected if $\mathrm{NisC}$ was not essential for the biosynthesis of nisin, it can be concluded that NisC is essential for nisin maturation.

Nisin induction of the knock-out strains $(\Delta n i s B, \Delta n i s T$, $\Delta n i s C$ and $\Delta n i s I)$ did not result in full restoration of transcription of the nisin operons. A lower transcription level of the nisin operons is likely to explain the lower immunity level of induced mutant strains compared to nisin-producing strains (Dodd et al., 1996). A wild-type level of transcription of the nisin operons might require gradually increasing nisin concentrations as in a nisin producer and such fine-tuning may not occur when nisin is externally added at a certain time point to mutant strains. The increase in immunity levels of the nisin mutant strains by nisin induction could also be a result of induction of nisin-inducible genes other than nisABTCIPRKFEG. If such genes did exist, their promoter would most likely share sequence similarity with the nisin-inducible promoters in front of nis $A$ and nis $F$ (de Ruyter et al., 1996; Ra et al., 1996). The Southern blot analysis of DNA of a nisin-producing strain using a degenerate probe recognizing the conserved sequences of the nis $A$ and nisF promoters (de Ruyter et al., 1996; $\mathrm{Ra}$ et al., 1996) suggests that a nisin-producing strain does not contain additional nisin-inducible promoters. Therefore, the increase in the level of nisin immunity of the nisin mutant strains observed after nisin induction is likely to be the sole result of the increased transcription of the two known nisin-inducible operons, i.e. nisABTCIP and nisFEG.

The NZ9747 strain with a deletion in the nisI gene did not produce the NisI protein but could still produce nisin. The lack of the NisI immunity protein affected the growth of the strain. It did not grow to as high cell densities as the parental strain and the maximum amount of nisin produced was also lower: approximately $20 \%$ of the highest amount that could be produced by the wild-type strain. The cells of strain NZ9747 could tolerate the amount of nisin that they produced themselves, probably due to the expression of the nisFEG genes, but the sensitivity to externally added nisin was approximately five times higher than in the wild-type. The nisin immunity level of strain NZ9747 showed that without the NisI lipoprotein the NisF, NisE and NisG immunity proteins can protect the cells to approximately $20 \%$ of the wild-type level. Duan et al. (1996) described from L. lactis a plasmid-encoded nisin 
resistance determinant consisting of only the nisRKFEG genes. The presence of this nisin resistance plasmid resulted in an immunity level of approximately $20 \%$ of a wild-type nisin producer. The nisin immunity level of strain NZ9747 corresponds well to the nisin resistance level of the nisin resistance plasmid containing the nisRKFEG genes. From these results some conclusions can be drawn concerning the question whether NisI cooperates with the NisFEG polypeptides or whether they represent separate immunity systems. Expressed to wild-type and higher levels without other nis-encoded genes NisI gives only $1-4 \%$ of the wild-type immunity level (Kuipers et al., 1993; Qiao et al., 1995). If NisI represents a non-cooperating immunity system, then the question arises why the immunity level of NZ9747 is only $20 \%$ of the wild-type level and is not in the range of $>95 \%$ as would be expected if NisI formed an independent immunity system. Therefore, NisI clearly cooperates with some of the transposon-encoded polypeptides, probably with the NisFEG polypeptides. The observed $80 \%$ reduction of nisin immunity in the NisIdeficient strain can be partly explained by assuming that the efficiency of the immunity proteins is also influenced by the presence of functional complexes with other nisencoded membrane proteins, e.g. NisB, NisP or NisT. This has been suggested by previous results of Kuipers $e t$ al. (1993) showing that expression of nisI resulted in at most $1-4 \%$ of wild-type immunity, whereas when nis was expressed together with the nisABTC genes the immunity level was higher, ranging between 8 and $20 \%$ of the wild-type level. Thus, full nisin immunity seems to require nisin production and fully induced nisI and nisFEG genes. This notion is further supported by recent studies showing that the production of antisense-nisEG or antisense-nis $G$ RNA severely reduced the immunity levels in the L. lactis strain tested (Immonen \& Saris, 1998).

The killing activity of nisin requires pore formation in the target cell. It has been speculated that NisI as a lipoprotein could destabilize this pore formation (Entian \& de Vos 1996; Saris et al., 1996) or assist the putative transport function of NisFEG. Recently Qiao (1996) has shown by circular dichroism (CD) spectroscopy and biomolecular interaction analysis (BIA) that purified Nisl does indeed have physical interactions with nisin. On the basis of sequence homology the nisFEG-encoded proteins belong to the family of $\mathrm{ABC}$ transporters (Siegers \& Entian, 1995), which strongly suggests that nisin immunity is dependent on nisin translocation. Our present view of nisin immunity comprises cooperative interactions of NisI with the putative NisFEG complex, in which translocation of nisin from the membrane to the cell exterior by NisFEG activity is mediated or facilitated by NisI interactions with nisin.

\section{ACKNOWLEDGEMENTS}

We thank Roland Siezen, Michiel Kleerebezem and Cindy van Kraaij for critically reading the manuscript. This work was in part supported by contract BIOT-CT91-0265 of the BRIDGE programme of the European Union.

\section{REFERENCES}

Buchman, G. W., Banerjee, S. \& Hansen, J. N. (1988). Structure, expression and evolution of a gene encoding the precursor nisin, a small peptide antibiotic. J Biol Chem 263, 16260-16266.

Casadaban, M. J., Chou, J. \& Cohen, S. N. (1980). In vitro gene fusions that join an enzymatically active $\beta$-galactosidase segment to amino-terminal fragments of exogenous proteins: Escherichia coli plasmid vectors for the detection and cloning of transcriptional initiation signals. J Bacteriol 143, 971-980.

Delves-Broughton, J., Blackburn, P., Evans, R. J. \& Hugenholtz, J. (1996). Applications of the bacteriocin nisin. Antonie Leeuwenhoek 69, 193-202.

Dodd, H. M., Horn, N., Chan, W. C., Giffard, C. J., Bycroft, B. W., Roberts, G. C. K. \& Gasson, M. J. (1996). Molecular analysis of the regulation of nisin immunity. Microbiology 142, 2385-2392.

Duan, K., Harvey, M. L., Liu, C.-Q. \& Dunn, N. W. (1996). Identification and characterization of a mobilizing plasmid, pND300, in Lactococcus lactis M189 and its encoded nisin resistance determinant. J Appl Bacteriol 81, 493-500.

Engelke, G., Gutowski-Eckel, Z., Hammelmann, M. \& Entian, K.-D. (1992). Biosynthesis of the lantibiotic nisin: genomic organization and localization of the NisB protein. Appl Environ Microbiol 58, 3730-3743.

Engelke, G., Gutowski-Eckel, Z., Kiesau, P., Siegers, K., Hammelmann, M. \& Entian, K.-D. (1994). Regulation of nisin biosynthesis and immunity in Lactococcus lactis 6F3. Appl Environ Microbiol 60, 814-825.

Entian, K.-D. \& de Vos, W. M. (1996). Genetics of subtilin and nisin biosynthesis. Antonie Leeuwenhoek 69, 109-177.

Gasson, M. J. (1983). Plasmid complements of Strepococcus lactis NCDO 712 and other lactic streptococci after protoplast-induced curing. J Bacteriol 154, 1-9.

Gross, E. \& Morell, J. L. (1971). The structure of nisin. J Am Chem Soc 93, 4634-4635.

Holo, H. \& Nes, I. F. (1989). High-frequency transformation, by electroporation, of Lactococcus lactis subsp. cremoris grown with glycine in osmotically stabilized media. Appl Environ Microbiol 55, 3119-3123.

Hurst, A. (1981). Nisin. Adv Appl Microbiol 27, 85-123.

Immonen, T. \& Saris, P. E. J. (1998). Characterization of the nisFEG operon of the nisin $\mathrm{Z}$ producing Lactococcus lactis subsp. lactis N8 strain. DNA Seq 67, 1-12.

Immonen, T., Ye, S., Ra, R., Qiao, M., Paulin, L. \& Saris, P. E. J. (1995). The codon usage of the nis $Z$ operon in Lactococcus lactis N8 suggests a non-lactococcal origin of the conjugative nisinsucrose transposon. DNA Seq 5, 203-208.

Kaletta, C. \& Entian, K.-D. (1989). Nisin, a peptide antibiotic: cloning and sequencing of the nis $A$ gene and posttranslational processing of its peptide product. J Bacteriol 171, 1597-1601.

Kuipers, O. P., Boot, H. J. \& de Vos, W. M. (1991). Efficient random mutagenesis method with adjustable mutation frequency by use of PCR and dITP. Nucleic Acids Res 19, 4558.

Kuipers, O. P., Beerthuyzen, M. M., Siezen, R. J. \& de Vos, W. M. (1993). Characterization of the nisin gene cluster nisABTCIPR of Lactococcus lactis; requirement of expression of nis $A$ and nisI genes for development of immunity. Eur J Biochem 216, 281-291.

Kuipers, O. P., Beerthuyzen, M. M., de Ruyter, P. G. G. A., Luesink, E. J. \& de Vos, W. M. (1995). Autoregulation of nisin biosynthesis in Lactococcus lactis by signal transduction. J Biol Chem 270, 27299-27304.

Leenhouts, K. J., Gietema, J., Kok, J. \& Venema, G. (1991). 
Chromosomal stabilization of the proteinase genes in Lactococcus lactis. Appl Environ Microbiol 57, 2568-2575.

van der Meer, J. R., Polman, J., Beerthuyzen, M. M., Siezen, R. J., Kuipers, O. P. \& de Vos, W. M. (1993). Characterization of the Lactococcus lactis nisin A operon genes nisP, encoding a subtilisin-like serine protease involved in precursor processing, and nisR, encoding a regulatory protein involved in nisin biosynthesis. J Bacteriol 175, 2578-2588.

Qiao, M. (1996). Lantibiotic nisin of Lactococcus lactis: biosynthesis, immunity and regulation. Doctoral thesis, University of Helsinki. ISBN 952-90-8180.

Qiao, M. \& Saris, P. E. J. (1996). Evidence for a role of NisT in transport of the lantibiotic nisin produced by Lactococcus lactis N8. FEMS Microbiol Lett 144, 89-93.

Qiao, M., Immonen, T., Koponen, O. \& Saris, P. E. J. (1995). The cellular location and effect on nisin immunity of the Nisl protein from Lactococcus lactis N8 expressed in Escherichia coli and $L$. lactis. FEMS Microbiol Lett 131, 75-80.

Qiao, M., Ye, S., Koponen, O., Ra, R., Usabiaga, M., Immonen, T. \& Saris, P. E. J. (1996). Regulation of the nisin operons in Lactococcus lactis. J Appl Bacteriol 80, 626-634.

Ra, R. \& Saris, P. E. J. (1995). Characterization of procaryotic mRNAs by RT/PCR technique. BioTechniques 18, 792-795.

Ra, R., Qiao, M., Immonen, T., Pujana, I. \& Saris, P. E. J. (1996). Genes responsible for nisin synthesis, regulation and immunity form a regulon of two operons and are induced by nisin in Lactococcus lactis N8. Microbiology 142, 1281-1288.

Rauch, P. J. G. \& de Vos, W. M. (1992). Characterization of the novel nisin-sucrose conjugative transposon $\operatorname{Tn} 5276$ and its integration in Lactococcus lactis. J Bacteriol 174, 1280-1287.

de Ruyter, P. G. G. A., Kuipers, O. P., Beerthuyzen, M. M., van Alen, I. J. \& de Vos, W. M. (1996). Functional analysis of promoters in the nisin gene cluster of Lactococcus lactis. J Bacteriol 178, 3434-3439.

Sambrook, J., Fritsch, E. F. \& Maniatis, T. (1989). Molecular Cloning: a Laboratory Manual, 2nd edn. Cold Spring Harbor, NY : Cold Spring Harbor Laboratory.
Sanger, F., Nicklen, S. \& Coulson, A. R. (1977). DNA sequencing with chain-terminating inhibitors. Proc Natl Acad Sci USA 74, 5463-5467.

Saris, P. E. J., Immonen, T., Reis, M. \& Sahl, H.-G. (1996). Immunity to lantibiotics. Antonie Leeuwenhoek 69, 151-159.

Siegers, K. \& Entian, K.-D. (1995). Genes involved in immunity to the lantibiotic nisin produced by Lactococcus lactis 6F3. Appl Environ Microbiol 61, 1082-1089.

Siegers, K., Heinzman, S. \& Entian, K.-D. (1996). Biosynthesis of lantibiotic nisin - posttranslational modification of its prepeptide occurs at a multimeric membrane-associated lanthionine synthetase complex. J Biol Chem 271, 12294-12301.

Steen, M. T., Chung, Y. J. \& Hansen, J. N. (1991). Characterization of the nisin gene as part of a polycistronic operon in the chromosome of Lactococcus lactis ATCC 11454. Appl Environ Microbiol 57, 1181-1188.

Stock, J. B., Stock, A. M. \& Mottonen, J. M. (1990). Signal transduction in bacteria. Nature 344, 395-400.

Vos, P., van Asseldonk, M., van Jeveren, F., Siezen, R. J., Simons, G. \& de Vos, W. M. (1989). A maturation protein is essential for the production of active forms of Lactococcus lactis SK11 serine proteinase located in or secreted from the cell envelope. J Bacteriol 171, 2795-2802.

de Vos, W. M., Beerthuyzen, M. M., Luesink, E. L. \& Kuipers, O. P. (1995a). Genetics of the nisin operon and the sucrose-nisin conjugative transposon Tn5276. In Genetics of Streptococci, Enterococci and Lactococci (Development of Biological Standards vol. 85), pp. 617-625. Edited by J. J. Ferretti, M. S. Gilmore, T. R. Klaenhammer \& F. Brown. Basel: Karger.

de Vos, W. M., Kuipers, O. P., van der Meer, J. R. \& Siezen, R. J. (1995b). Maturation pathway of nisin and other lantibiotics: post-translationally modified antimicrobial peptides exported by Gram-positive bacteria. Mol Microbiol 17, 429-437.

Received 25 November 1998; revised 8 February 1999; accepted 12 February 1999. 



\title{
Role of multiple gene copies in particulate methane monooxygenase activity in the methane-oxidizing bacterium Methylococcus capsulatus Bath
}

\author{
Sergei Stolyar, ${ }^{1}$ Andria M. Costello, ${ }^{3}$ Tonya L. Peeples ${ }^{3} \dagger$ \\ and Mary E. Lidstrom ${ }^{1,2}$ \\ Author for correspondence: Mary E. Lidstrom. Tel: +1 206616 5282. Fax: +1 2066165721. \\ e-mail: lidstrom $\hat{a}$ u.washington.edu
}

1,2 Departments of Chemical Engineering ${ }^{1}$ and Microbiology², University of Washington, Box 351750, Seattle, WA 98195 , USA

3 Environmental Engineering Science 13878, California Institute of Technology, Pasadena, CA 91125 , USA

\begin{abstract}
Genes for the subunits of particulate methane monooxygenase, PmoABC, have been sequenced from the $\gamma$-proteobacterial methanotroph Methylococcus capsulatus Bath. M. capsulatus Bath contains two complete copies of pmoCAB, as well as a third copy of pmoC. The two pmoCAB regions were almost identical at the nucleotide sequence level, differing in only 13 positions in $3183 \mathrm{bp}$. At the amino acid level, each translated gene product contained only one differing residue in each copy. However, the pmoC3 sequence was more divergent from the two other pmoC copies at both the far $\mathrm{N}$-terminus and far C-terminus. Chromosomal insertion mutations were generated in all seven genes. Null mutants could not be obtained for pmoC3, suggesting that it may play an essential role in growth on methane. Null mutants were obtained for pmoC1, pmoC2, pmoA1, pmoA2, pmoB1 and pmoB2. All of these mutants grew on methane, demonstrating that both gene copies were functional. Copy 1 mutants showed about two-thirds of the wild-type whole-cell methane oxidation rate, while copy 2 mutants showed only about one-third of the wildtype rate, indicating that both gene copies were necessary for wild-type particulate methane monooxygenase activity. It was not possible to obtain double null mutants that were defective in both pmo copies, which may indicate that some expression of pMMO is important for growth.
\end{abstract}

Keywords: methane monooxygenase, methanotroph, duplicate genes, $p m o$

\section{INTRODUCTION}

Methanotrophs are a group of Proteobacteria that utilize methane as a sole source of carbon and energy (Hanson et al., 1990). The initial transformation involves the conversion of methane to methanol by methane monooxygenase (MMO). Two types of MMO are known, a cytoplasmic or soluble form (sMMO) and a membranebound or particulate form ( $\mathrm{pMMO}$ ). All known meth-

\footnotetext{
†Present address: Dept of Chemical and Biochemical Engineering, University of lowa, lowa City, IA 52242, USA.

Abbreviations: $\mathrm{pMMO}$, particulate methane monooxygenase; sMMO, soluble methane monooxygenase; NMS, nitrate mineral salts medium; NMSF, NMS medium containing iron and formate.

The GenBank accession numbers for the sequences reported in this paper are L40804 (for the fragment containing pmoC1), U94337 (for the copy 2 pmo gene cluster) and AF091320 (for the fragment containing pmoC3).
}

anotrophs contain the pMMO, but the sMMO is found in only a few methanotrophs, as a second enzyme (Hanson et al., 1990; Koh et al., 1993; Nakajima et al., 1992). In those strains that contain both enzymes, sMMO is expressed only under copper-limitation (Prior \& Dalton, 1985a; Smith \& Dalton, 1989). The sMMO is an NADH-linked iron enzyme with a broad substrate specificity (Colby \& Dalton, 1976; Fox et al., 1989; Green \& Dalton, 1989). The genes for the subunits of sMMO have been cloned and sequenced from Methylococcus capsulatus Bath (Stainthorpe et al., 1990), Methylosinus trichosporium OB3b (Cardy et al., 1991) and Methylocystis sp. strain M (McDonald et al., 1997). Insertion mutants in sMMO genes in Methylosinus trichosporium OB3b still express pMMO normally (Martin \& Murrell, 1995). Recent studies have suggested that in Methylococcus capsulatus Bath and Methylosinus trichosporium $\mathrm{OB} 3 \mathrm{~b}$, transcription of the sMMO 
genes is negatively regulated by copper (Nielsen et al., 1997).

The $\mathrm{pMMO}$ is a copper enzyme with a relatively narrow substrate specificity, and it contains at least three subunits, of approximately 45, 26 and $23 \mathrm{kDa}$ (Smith \& Dalton, 1989; Nguyen et al., 1994, 1998; Zahn \& DiSpirito, 1996). The $26 \mathrm{kDa}$ subunit apparently contains the active site, as it binds the suicide inhibitor acetylene (Prior \& Dalton, 1985b; DiSpirito et al., 1992). Hybridization studies have suggested that methanotrophs contain multiple copies of genes encoding the 45 and $26 \mathrm{kDa}$ subunits $(p m o B 1$ and $p m o A 1$, respectively) (Semrau et al., 1995). One copy of the genes encoding these two subunits was cloned and sequenced, and the genes were found to be adjacent to each other in the order pmoA1-pmoB1 (Semrau et al., 1995). In addition, a gene encoding the $23 \mathrm{kDa}$ subunit ( $p m o \mathrm{C} 1$ ) has been shown to be present upstream of pmoA1 (Nguyen et al., 1996). pmoA1 and pmoB1 showed substantial similarity to genes encoding the analogous subunits of a related enzyme, ammonia monooxygenase (Semrau et al., 1995), which are also present in multiple copies in nitrifying bacteria (McTavish et al., 1993; Norton et al., 1996). In the nitrifiers, the genes are also organized in a cluster in the order amoCAB with an additional, single copy of amoC (Klotz et al., 1997; Sayavedra-Soto et al., 1998). In Nitrosomonas europaea, an insertion mutant defective in one of the amo $A$ genes showed slower growth than the wild-type, while a mutant containing an insertion in the other amoA gene showed normal growth (Hommes et al., 1998). However, mutants are not available in the other amo genes. A $3.3 \mathrm{~kb}$ transcript covering $p m o A$, $p m o B$ and $p m o C$ as well as smaller transcripts are detectable in Metbylococcus capsulatus Bath and Methylosinus trichosporium OB3b expressing pMMO, but it is not known which of the sets of genes is responsible for these transcripts (Nielsen et al., 1997). Likewise, analogous transcripts have been detected in nitrifying bacteria, and it has been shown that the amoA mutant showing slower growth also has decreased amounts of these transcripts (Hommes et al., 1998; Sayavedra-Soto et al., 1998).

In this paper, we present the entire sequence of both $p m o C A B$ gene clusters and a third copy of $p m o C$ from Methylococcus capsulatus (Bath), as well as the phenotypes of insertion mutants generated in each of the seven genes.

\section{METHODS}

Bacterial strains, plasmids and growth conditions. Escherichia coli strains DH $5 \alpha$, DH $5 \alpha \mathrm{MCR}$ (Bethesda Research Laboratories), Inv $\alpha \mathrm{F}^{\prime}$ (Invitrogen) and S17-1 (Simon et al., 1983) were used in this study (Table 1). They were grown in LB medium in the presence of appropriate antibiotics as described by Sambrook et al. (1989). Methylococcus capsulatus Bath was grown on nitrate mineral salts medium (NMS) (Whittenbury \& Dalton, 1981) in batch culture at $42{ }^{\circ} \mathrm{C}$ with or without copper added as $\mathrm{CuSO}_{4} \cdot 5 \mathrm{H}_{2} \mathrm{O}(10 \mu \mathrm{M}$ final concentration), with a $1: 1(\mathrm{v} / \mathrm{v}) \mathrm{CH}_{4} /$ air ratio in the head space, or on agar plates with the same medium. In some cases
NMS without copper, with $0.5 \mathrm{mM}$ ferrous sulfate and $1 \mathrm{mM}$ formate (NMSF) was used to grow bacteria with sMMO expressed. All M. capsulatus Bath mutants were grown from frozen cultures and tested by diagnostic PCR after growth to ensure that the insertion mutations were correct.

DNA manipulations. Plasmid isolation, E. coli transformation, restriction enzyme digestion, ligation, blunting ends with $\mathrm{T} 4$ DNA polymerase, or filling in ends with Klenow enzyme were carried out as described by Sambrook et al. (1989). The chromosomal DNA of $M$. capsulatus Bath grown in batch culture was isolated by the procedure of Marmur (1961). For the insertion mutants, chromosomal DNA was isolated from cells grown on agarose plates. In this case, cells were washed from the agarose surface using $3 \mathrm{ml}$ TEN $(50 \mathrm{mM}$ Tris/ EDTA $+150 \mathrm{mM} \mathrm{NaCl}$ ) and the liquid was collected in $25 \mathrm{ml}$ Corex tubes. Tubes were spun for $5 \mathrm{~min}$ at $10000 \mathrm{~g}$ and $4{ }^{\circ} \mathrm{C}$ and the supernatant poured off. The pellet was resuspended by adding $3 \mathrm{ml}$ TEN with $4 \mathrm{mg}$ lysozyme $\mathrm{ml}^{-1}$ and incubated at $37^{\circ} \mathrm{C}$ for $1 \mathrm{~h}$. Next, $3 \mathrm{ml}$ TEN with $4 \%$ (w/v) SDS was added to the tubes and incubated in a $45-50{ }^{\circ} \mathrm{C}$ water bath until the solution was clear (approximately $30 \mathrm{~min}$ ). DNA was extracted using phenol and precipitated using ethanol by standard procedures (Sambrook et al., 1989).

DNA sequencing. DNA sequencing was carried out by the Caltech Sequencing Facility and the University of Washington Sequencing Facility, with an Applied Biosystems automated sequencer, from both strands.

DNA-DNA hybridization. DNA-DNA hybridizations were carried out with dried agarose gels as described by Meinkoth \& Wahl (1984) at $68^{\circ} \mathrm{C}$ for DNA fragment probes or $42^{\circ} \mathrm{C}$ for oligonucleotide primer probes. For hybridizations, $6 \times$ SSC $(1 \times$ SSC is $0.15 \mathrm{M} \mathrm{NaCl}$ and $0.015 \mathrm{M}$ sodium citrate) was used; for washes, $0.5 \times$ SSC was used. Dried gels are not appropriate for DNA fragments less than $0.8 \mathrm{~kb}$, and for these gels, nucleic acids were transferred to a nylon membrane $\left(\mathrm{Hybond} \mathrm{N}^{+}\right.$) by capillary blotting and treated according to the vendor's recommendation. For DNA labelling, a randomprimed DNA labelling kit (Amersham) or direct nucleic acid labelling and detection systems (Amersham) were used for radioactive or non-radioactive labelling, respectively. T4 polynucleotide kinase (Boehringer Mannheim) was used for oligonucleotide labelling.

PCR. PCR was performed in $50 \mu \mathrm{l}$ reaction mixtures in $0.5 \mathrm{ml}$ microcentrifuge tubes. Reactions were carried out in a PerkinElmer GeneAmp PCR System 9600 thermal cycler. Thirty cycles of $92^{\circ} \mathrm{C}$ for $1 \mathrm{~min} ; 55^{\circ} \mathrm{C}$ for $1 \mathrm{~min} ; 72^{\circ} \mathrm{C}$ for $1 \mathrm{~min}$ were performed followed by a final extension of $5 \mathrm{~min}$ at $72{ }^{\circ} \mathrm{C}$ to amplify fragments up to $3 \mathrm{~kb}$. To amplify fragments more than $3 \mathrm{~kb}$, the program recommended by Boehringer Mannheim for the Expand PCR System was used: 2 min at $92^{\circ} \mathrm{C}, 10$ cycles of $92^{\circ} \mathrm{C}$ for $15 \mathrm{~s}, 57^{\circ} \mathrm{C}$ for $30 \mathrm{~s}, 68^{\circ} \mathrm{C}$ for $4 \mathrm{~min}$ and 15 cycles with elongation times of $20 \mathrm{~s}$, with a final step of $72^{\circ} \mathrm{C}$ for $7 \mathrm{~min}$. Taq polymerase (Boehringer Mannheim) was used. Primers used were as follows. For the Kmcassette (accession no. X06404): KBF1 (5'-CGATAGATTGTCGCACCTG- $\left.3^{\prime}\right)$ and KBR2 (5'-CACTTTCTGGCTGGATG- $3^{\prime}$ ). For amplification of pmo genes (accession no. L40804): CSS1F (5'-CAAACAATGGCAGCAACAAC-3') 118 to $138 \mathrm{bp}, \mathrm{CSS} 2 \mathrm{~F}\left(5^{\prime}\right.$-CCTGTGGGTGCGGTGGTAC-3') 222 to $241 \mathrm{bp}$, CSSK4F (5'-GGCACTGGCCGTCATGGGCAC$\left.3^{\prime}\right) 799$ to $820 \mathrm{bp}$, CSS9F (5'-GCCACACCTTCTGGTTCATGG-3') 727 to $747 \mathrm{bp}$, CSS9R (5'-GCCTTCGTCCACGGCTTC-3') 875 to $893 \mathrm{bp}$, CSS10R (5'-AGATGAACGCCGCAAAAC-3') 601 to $618 \mathrm{bp}$, CSS16R (5'-GTGAGCCACTTCTTGTCCAGC-3') 172 to $190 \mathrm{bp}$, CSS17R (5'-GAGCT- 
Table 1. Bacterial strains and plasmids used in this study

\begin{tabular}{|c|c|c|}
\hline Strain or plasmid & Relevant trait(s) & Source or reference \\
\hline \multicolumn{3}{|l|}{ E. coli } \\
\hline $\mathrm{DH} 5 \alpha$ & $\begin{array}{l}(\phi 80 \mathrm{~d} l a c Z \Delta \mathrm{M} 15) \Delta(\operatorname{lac} Z \mathrm{Y}-\arg F) \mathrm{U} 169 \text { deoR } \\
\left.\text { recA1 endA1 bsdR17( } \mathrm{r}_{\mathrm{k}}^{-} \mathrm{m}_{\mathrm{k}}^{+}\right) \text {supE44 gyrA96 } \\
\text { relA }\end{array}$ & $\begin{array}{l}\text { Bethesda Research } \\
\text { Laboratories }\end{array}$ \\
\hline DH5 $\alpha$ MCR & $\mathrm{DH} 5 \propto m c r A \Delta(m m r-h s d R M S-m s r B C)$ & $\begin{array}{l}\text { Bethesda Research } \\
\text { Laboratories }\end{array}$ \\
\hline $\ln v \alpha \mathrm{F}^{\prime}$ & 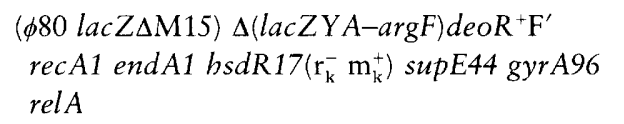 & Invitrogen \\
\hline S17-1 & thi pro recA hsdR RP4-2-tet:: $\mathrm{Mu}$ aphA::Tn7 & Simon et al. (1983) \\
\hline \multicolumn{3}{|l|}{ M. capsulatus Bath } \\
\hline T401 & Uncharacterized $\operatorname{Tn} 5$ chromosomal insertion & This study \\
\hline MAK5 & $p m o A 1:: \mathrm{Km}^{\mathrm{r}}$ & This study \\
\hline MAK 16 & pmoA2:: $\mathrm{Km}^{\mathrm{r}}$ & This study \\
\hline MBK1-1 & pmoB1:: $\mathrm{Km}^{r}$ & This study \\
\hline MBK206 & $p m o B 2:: \mathrm{Km}^{\mathrm{r}}$ & This study \\
\hline MCK60 & pmoC1:: $\mathrm{Km}^{\mathrm{r}}$ & This study \\
\hline MCK62 & pmoC2:: $\mathrm{Km}^{\mathrm{r}}$ & This study \\
\hline MBS2 & $p m o B 1:: \mathrm{Sm}^{\mathrm{r}}$ & This study \\
\hline MBS202 & $p m o B 2:: \mathrm{Sm}^{\mathrm{r}}$ & This study \\
\hline \multicolumn{3}{|l|}{ Plasmids } \\
\hline $\mathrm{pUC18} / 19 \mathrm{Ap}^{\mathrm{r}}$ & $\operatorname{lac} Z$ & $\begin{array}{l}\text { Yanisch-Perron et al. } \\
(1985)\end{array}$ \\
\hline pCR II & $\mathrm{Ap}^{r} \mathrm{Km}^{\mathrm{r}} l a c Z \alpha$ & Invitrogen \\
\hline pCR 2.1 & $A p^{r} K m^{r} l a c Z \alpha$ & Invitrogen \\
\hline pUC4K & $\mathrm{Ap}^{r} \mathrm{Km}^{r}$ & Vieira \& Messing (1982) \\
\hline pAYC61 & $A p^{r} T c^{r}$ & Chistoserdov et al. (1994) \\
\hline pBR325 & $\mathrm{Ap}^{r} \mathrm{Cm}^{r} \mathrm{Tc}^{r}$ & Bolivar $(1978)$ \\
\hline $\mathrm{pBR} 325 \Omega$ & $\operatorname{pBR} 325:: \Omega S m^{r} / S^{r}$ & $\begin{array}{l}\text { C. Murrell, University of } \\
\text { Warwick, UK }\end{array}$ \\
\hline pSUP2021 & $A p^{r} K m^{r}$ & Simon et al. (1983) \\
\hline pRK2013 & $\mathrm{Km}^{\mathrm{r}}$ & $\begin{array}{l}\text { Figurski \& Helinski } \\
(1979)\end{array}$ \\
\hline pAMC100 & pUC19 with $2.9 \mathrm{~kb} \mathrm{Kpnl}$ insert & Semrau et al. (1995) \\
\hline pAMC101 & pUC19 with $1.8 \mathrm{~kb}$ KpnIPstI insert & Semrau et al. (1995) \\
\hline pAMC102 & pUC19 with $2.5 \mathrm{~kb}$ EcoRI insert & Semrau et al. (1995) \\
\hline pAMCI03 & pUC19 with $1.0 \mathrm{~kb}$ EcoR insert & This study \\
\hline
\end{tabular}

GCACCACCAATGGTTG-3') 135 to $155 \mathrm{bp}$, CSS19R (5'GTACCACCGCACCCTCAGG-3') 222 to $241 \mathrm{bp}, \operatorname{ASS} 1 \mathrm{~F}\left(5^{\prime}\right.$ CTGGGACTTCTGGTCGGACTG-3') 1202 to $1223 \mathrm{bp}$. Copy 2 specific (accession no. U94337) : ESSR (5'-CCTGAACGTCTAAAATCCAGC-3') 3242 to 3262 bp. For amplification of pmoC3 (accession no. AF091320): C3F1 (5'GGCATCAATCCAACACC-3') 1 to 17 bp, C3R 1 (5'-GCGGACGGTGGCTCCCTGG-3') 855 to 874 bp.

All sequence generated by PCR was confirmed from a second, separate amplification reaction.

Computer analysis. Translation and analyses of DNA and DNA-derived polypeptide sequences were carried out using Genetic Computer Group (Wisconsin) programs and the National Center for Biotechnology Information BLAST server using the BLAST algorithm (Altschul et al., 1990, 1997). and a control strain. The $\mathrm{Km}^{\mathrm{r}}$ cassette from pUC4K and the
$\Omega S m^{r} / S p^{r}$ cassette from $p B R 325 \Omega$ were used as selective inactivating markers. pBR325 $\Omega$ was constructed in the laboratory of J. C. Murrell (University of Warwick, UK) using the omega fragment from pHP45-omega (Prentki \& Kirsh, 1984). The constructs with mutated genes were subcloned into the suicide vector pAYC61 (Chistoserdov et al., 1994) and introduced into $M$. capsulatus Bath by conjugation. E. coli S17-1 was used as donor. Matings were conducted as described by Stolyar et al. (1995). Donor and recipient cells (ratio $1 / 5-1 / 10$ ) were mixed and resuspended in NMS medium, then cells were pelleted, resuspended by pipetting in $30-40 \mu \mathrm{l}$ NMS and plated as a spot on NMS agar. Plates were incubated at $37^{\circ} \mathrm{C}$ for $48 \mathrm{~h}$ under methane/air, and then cells were transferred to selective plates. Mutants of $M$. capsulatus Bath were selected on plates with $50 \mu \mathrm{g} \mathrm{Km} \mathrm{ml}^{-1}$ or $100 \mu \mathrm{g} \mathrm{Sm}$ and $\mathrm{Sp} \mathrm{ml} \mathrm{m}^{-1}$ and screened on plates with $75 \mu \mathrm{g} \mathrm{Ap} \mathrm{ml}^{-1}$ to test for vector absence. Ap-sensitive clones were examined by hybridization to DNA blots with gene-specific and vector-specific 
probes to verify recombinational events, as well as by PCR amplification using primers for diagnostic regions.

A control strain was generated for comparative phenotypic studies in which a $\operatorname{Tn} 5\left(\mathrm{Km}^{\mathrm{r}}\right.$ gene $)$ was inserted into a random chromosomal location by using pSUP2021 and pRK2013 (as a helper plasmid). This strain shows normal growth on methane, and is able to grow on methane in the presence of kanamycin.

sMMO assay. sMMO activity was detected on plates using the naphthalene plate assay described by Graham et al. (1992). Maximum sMMO activity on plates was achieved when cells were grown on NMSF medium.

Whole-cell methane oxidation assay. Rates of whole-cell methane-dependent $\mathrm{O}_{2}$ uptake were determined polarographically using an oxygen electrode chamber at $42^{\circ} \mathrm{C}$, as described by McNerney \& O'Connor (1980). Cells were washed and resuspended in $50 \mathrm{mM}$ HEPES buffer $\mathrm{pH} 7 \cdot 0$.

\section{RESULTS}

\section{Sequencing of pmoC1}

A $2.9 \mathrm{~kb} K p n \mathrm{I}$ fragment of M. capsulatus Bath DNA had been previously cloned (pAMC100), and sequencing of the $3^{\prime}$ region revealed $p m o A 1$ and part of $p m o B 1$ (Fig. 1; Semrau et al., 1995). A $1.8 \mathrm{~kb}$ KpnI-PstI fragment containing most of pmoA1 and $1 \mathrm{~kb}$ of the upstream region was subcloned into pUC19 to generate pAMC101 (Fig. 1), and the insert was sequenced. One ORF was found upstream of pmoA1. A region near the $\mathrm{N}$ terminus starting 10 residues after the first methionine revealed an almost perfect match to an amino acid sequence (AAAEAPLKDKKWLTFA) that had been determined by Edman degradation for the $23 \mathrm{kDa}$ pMMO subunit (Nguyen et al., 1998). The only discrepancy was that the underlined lysine was predicted by the nucleotide sequence to be a leucine. This ORF was designated pmoC1 and is predicted to encode a polypeptide of 260 amino acids with a molecular mass of $29000 \mathrm{Da}$, assuming it starts at the position determined by Edman degradation. A hydropathy analysis of pmoC1 predicts a minimum of three and a maximum of six membrane-spanning regions with no classical leader sequence at the $\mathrm{N}$-terminus. A search of both protein and DNA databases revealed significant identity with amoC sequences from nitrifiers (Klotz et al., 1997; Sayavedra-Soto et al., 1998) (44-54\% identity at the amino acid level).

\section{Sequencing and analysis of the second copy of pmo genes}

Hybridization experiments had suggested that part of the second copy of $p m o B$ was located on a $1.0 \mathrm{~kb} E c o$ RI fragment (Semrau et al., 1995). This fragment was cloned into pUC19 to generate pAMC103 (Fig. 1), and the insert was sequenced. This sequence showed high identity to the pmoB1 sequence, and an ORF was present whose predicted product showed high identity to PmoB1. All attempts to clone the upstream $K p n I$ and EcoRI fragments were unsuccessful, even with low- copy-number vectors. It has been suggested that these gene products may be toxic in alternative hosts (Semrau et al., 1995). Hybridization analysis of chromosomal DNA digested with different restriction enzymes and probed with $p m o A 1, B 1$ and $C 1$ sequences demonstrated that the segment of chromosomal DNA upstream of $p m o B 2$ contained $p m o A$ and $p m o C$ sequences similar to the genes previously characterized. Therefore, the sequence of this region was obtained by PCR, using Kminsertion strains to target the second copy.

To obtain the missing sequences for the second copy of pmo $A B$, strain MBK206 containing a $\mathrm{Km}$ insertion in the $K p n I$ site of $p m o B 2$ (Fig. 1 ; and see below) was used for amplification from the chromosome. The primers targeted the $5^{\prime}$ end of pmoA2 (ASSF1) and the Kmresistance cassette (KBF1), to amplify a fragment overlapping the unsequenced region. The use of the Kmresistance insertion mutant ensured that the amplified fragment was from copy 2 , not copy 1 . A PCR product with the expected size of $1.9 \mathrm{~kb}$ was obtained. This DNA fragment was cloned into the Invitrogen vector pCR2.1 and sequenced. As expected, it contained most of $p m o A 2$ and the $5^{\prime}$ portion of $p m o B 2$.

For the region containing $p m o C 2$, probing experiments had shown that $p m o C 2$ and the $5^{\prime}$ end of $p m o A 2$ were present on a $1.4 \mathrm{~kb}$ Sall fragment (data not shown). Assuming that $p m o C 2$ was similar in size to $p m o C 1$, this SalI fragment should contain all of $p m o C 2$ and $0.4 \mathrm{~kb}$ of DNA $5^{\prime}$ to pmoC2. Attempts to clone this SalI fragment were unsuccessful. Therefore, an inverse PCR procedure was used that involved the insertion mutant MCK62, which contains a $\mathrm{Km}$-resistance gene in the $B b s \mathrm{I}$ site of pmoC2 (Fig. 1; see below for details of mutant construction). First, the appropriate size fraction of Salldigested MCK62 DNA was isolated from a gel. This pool of DNA was then ligated, which joined the SalI fragments into a circle. This DNA was then digested with HindIII, which cuts within the Km-resistance gene but not within the pmoC2 region. This procedure separated $p m o C 2$ and its upstream region into two inverted parts flanked by portions of the $\mathrm{Km}$-resistance cassette. It was then possible to amplify the entire region using appropriate primers targeted to the ends of the $\mathrm{Km}$-resistance cassette (KBF1 and KBR2). A fragment of the correct size $(2 \mathrm{~kb})$ was obtained, and it was sequenced directly as a PCR product. Based on the known sequence for the first copy of $p m o C A$ and for the $\mathrm{Km}$-resistance cassette, we identified $p m o \mathrm{C} 2$, the $p m o C 2-p m o A 2$ intergenic region and $170 \mathrm{bp}$ of $p m o A$. The sequence of the $5^{\prime}$ end of $p m o C 2$ and the region immediately upstream of the translational start site was confirmed by direct PCR from chromosomal DNA, using appropriate primers. These data completed the sequence of all three subunits of the second copy of the pmo genes.

We have also amplified $3.5 \mathrm{~kb}$ and $3.1 \mathrm{~kb}$ fragments containing the entire $p m o C A B 2$ gene cluster. The $3.5 \mathrm{~kb}$ fragment containing all three genes plus the known upstream region was amplified using a primer specific to 

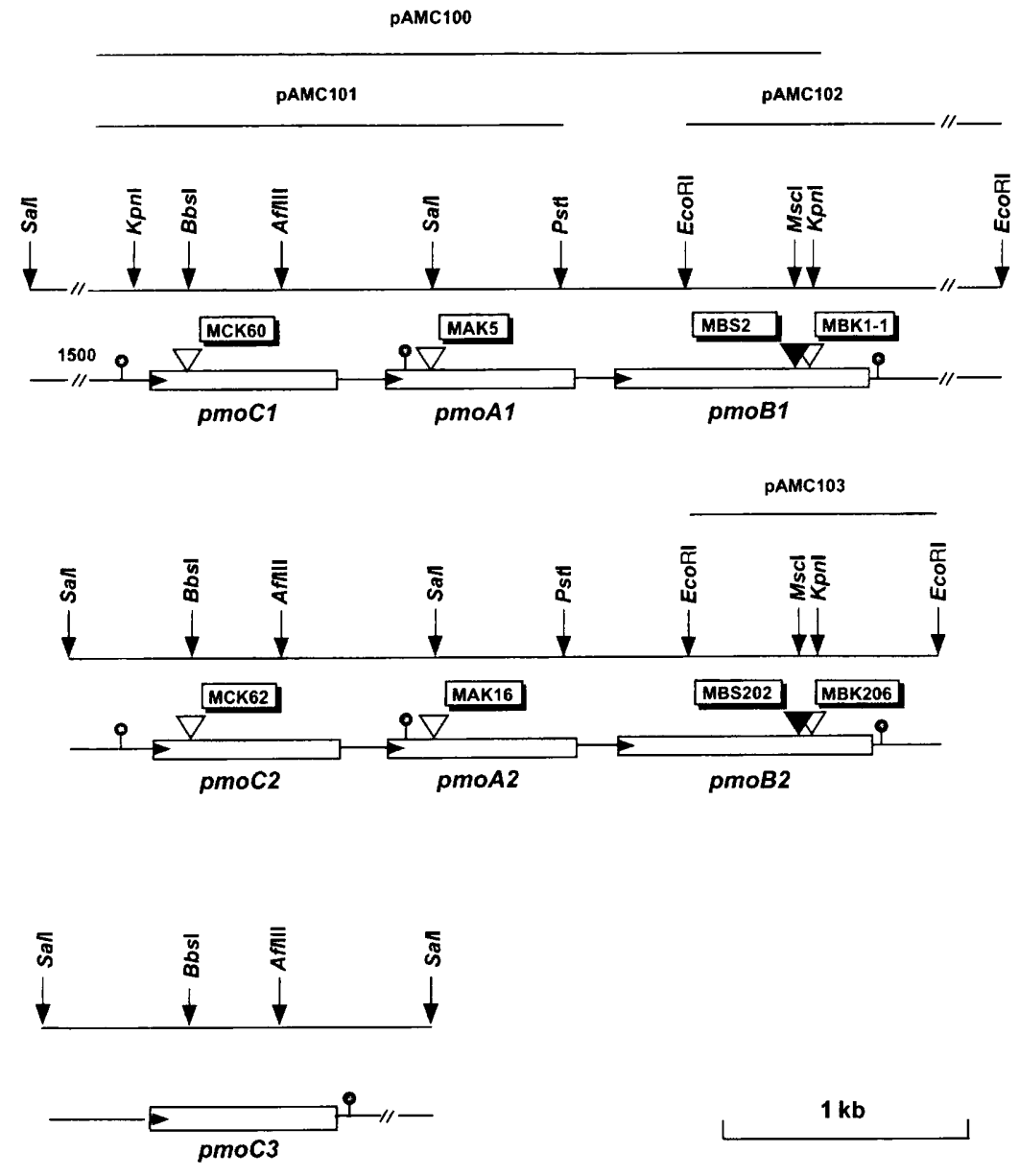

$\stackrel{5}{1}$

a region just inside the Sall site upstream of $p m o C 2$ and the ESSR 1 primer complementary to the region immediately downstream of $p m o B 2$. The primers used in amplifying the $3 \cdot 1 \mathrm{~kb}$ fragment were CSS1F and ESSR1. This produced a fragment with the same $3^{\prime}$ end as the $3.5 \mathrm{~kb}$ fragment, but with a shorter $5^{\prime}$ end that begins 6 nucleotides upstream of the start codon for pmoC2. Therefore, both fragments contain all three ORFs, but the smaller one lacks a $0 \cdot 4 \mathrm{~kb} 5^{\prime}$ region. These fragments were the expected size, confirming that the pmoCAB2 genes that have been sequenced are linked on the chromosome. We were able to clone the $3 \cdot 1 \mathrm{~kb}$ fragment using the pCR2.1 vector but were unable to clone the larger fragment. In addition, we were able to clone a PCR product containing a $400 \mathrm{bp}$ region upstream of the pmoC2 translational start site. These results suggest that the difficulties in cloning these genes are related to expression of $p m o C 2$.

The nucleotide sequence of the region containing the second copy of $p m o C A B$ was almost identical to the first copy. Starting with the ATG identified for $p m o C 1$, the sequences of $p m o C 1$ and $p m o C 2$ differ only in 3 nucleotides, which result in only one amino acid change, at residue 239, where PmoC1 contains an arginine and PmoC2 contains a serine (Fig. 2). However, the 125 bp sequence upstream of the start site for pmoC1 showed only $40 \%$ identity to the same region for $p m o C 2$. The $p m o C-p m o A$ intergenic region showed more divergence than the pmoC coding region, with differences in 5 of 164 nucleotides.

The two regions containing $p m o A B$ were even more similar at the nucleotide sequence level, differing in only 5 out of 2236 nucleotides. The predicted amino acid sequence of PmoA1 differs from that of PmoA2 only at residue 173, where PmoA1 contains an asparagine while PmoA2 contains a tyrosine. Likewise, the predicted amino acid sequences of PmoB1 and PmoB2 differ only at residue 385 , where $P$ moB1 contains a serine instead of an arginine in PmoB2. The pmoA1-pmoB1 and $p m o A 2-p m o B 2$ intergenic regions are identical. The sequences of the two gene copies begin to diverge 80 nucleotides downstream of the termination codon for pmoB, after which the identity drops to $35 \%$. Immediately before this divergent point are conserved sequences that could form a double-hairpin structure with a calculated $\Delta G^{\circ}$ of $-194.6 \mathrm{~kJ} \mathrm{~mol}^{-1}(-46.5 \mathrm{kcal}$ $\mathrm{mol}^{-1}$ ) for copy 1 and $-204.3 \mathrm{~kJ} \mathrm{~mol}^{-1}$ (-48.8 kcal $\mathrm{mol}^{-1}$ ) for copy 2. This structure is a candidate for a transcriptional terminator. Because of the similarity in the sequences of the two copies, in all cases they were sequenced at least twice from different DNA preparations, and in each case the sequences agreed exactly. 
PMOC3 MATTTAGGIAAIDRLLLDKKWLVFAIGIYTVFYLWVRWYEGVYGWSAGLDSFAPEFETYW

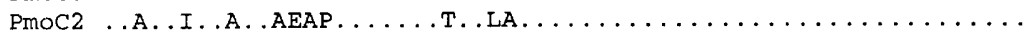

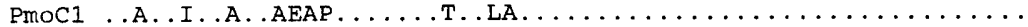

MNFLYTEIVLEIVTASILWGYLWKTRDRNLAALTPREELRRNFTHLVWLVAYAWAIYWGA

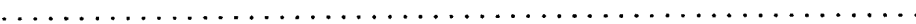

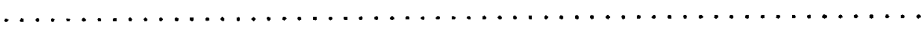

SYFTEQDGTWHQTIVRDTDFTPSHI IEFYLSYPIYIITGFAAF IYAKTRLPFFAKGISLP

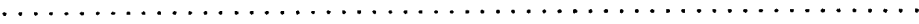

$\ldots \ldots \ldots \ldots \ldots \ldots \ldots \ldots$

YLVLVVGPFMILPNVGLNEWGHTFWFMEELFVAPLHYGFVIFGWLALAVMGTLTQTFYSF

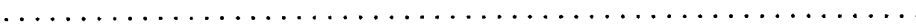

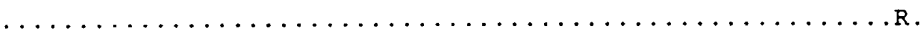

241 SHLFERD-LCPDIR 253

AQGGLGQS. . EAVDEGLIAK 260

AOGGLGQS. . EA
Fig. 2. Comparison of the three translated products of the pmoC genes. Periods denote residues identical to the $\mathrm{PmoC} 3$ sequence; $a$ dash denotes a gap.

\section{Construction of pmo gene disruptions and phenotypic characterization of mutants}

For the pmoA mutants, Km-resistance insertions were generated in the Sall site of pmoA1 in pAMC101, and were used in allelic exchange experiments to obtain insertions in the chromosome for both $p m o A 1$ and $p m o A 2$. For the $p m o C$ insertions, $\mathrm{Km}$-resistance insertions were generated in the BbsI site of pmoC1 in pAMC101, and were used to obtain insertions in the chromosome for both pmoC1 and pmoC2. For the $p m o B$ mutants, $\mathrm{Km}$-resistance insertions were generated in the $K p n I$ site of $p m o B 2$ in pAMC103, but in this case chromosomal insertions were only obtained in $p m o B 2$. Therefore, a second construction was generated with a $\mathrm{Km}$-resistance insertion in the $K p n \mathrm{I}$ site of $p m o B 1$ in pAMC102 and was used to generate chromosomal insertions in $p m o B 1$. Each of these recombination events was confirmed by hybridization and/or by PCR of specific pmo-Km cassette fragments. The hybridization experiments also confirmed previous results (Semrau et al., 1995) showing that two copies of $p m o A$ and $p m o B$ were present.

Mutants were isolated on plates designed either for pMMO or for sMMO expression, and tested for growth on both types of media. For pMMO expression, plates of NMS medium plus copper were used. For sMMO expression, several types of medium were tested with the wild-type, and it was determined by the naphthalene colorimetric assay that maximal sMMO expression could be achieved with NMS plates containing no added copper, but with added formate and iron (NMSF medium; see Methods). All of these mutants grew on methane on both types of media. On plates of NMSF medium, it was shown by the naphthalene colorimetric assay that the wild-type and the mutants exhibited substantial sMMO activity, which appeared similar by visual examination. On plates of NMS medium containing copper, none of the strains showed detectable sMMO activity, and were assumed to be expressing pMMO.

All of the mutants showed some genetic instability, due to recombination between the gene copies. Therefore, for phenotypic characterization, transfers were kept to a

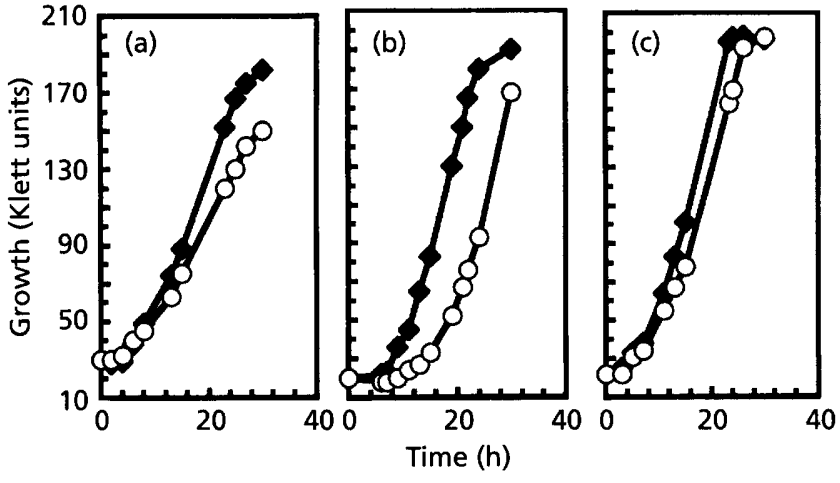

Fig. 3. Growth curves, determined from Klett readings with a no. 6 filter, of the insertion mutants for the pmo genes. (a) pmoC1: $\mathrm{Km}(\diamond)$ and $p m o C 2: \mathrm{Km}(\mathrm{O}) ;(\mathrm{b}) p m o A 1: \mathrm{Km}(\diamond)$ and pmoA2: $\mathrm{Km}(O) ;(c) p m o B 1: \mathrm{Km}(\diamond)$ and pmoB2: $\mathrm{Km}(O)$. Growth curves for the T401 strain (wild-type containing a Tn5 insertion) were the same as for the copy 1 mutants.

minimum and cultures were inoculated from plates that had been streaked directly from frozen stocks. To ensure that the cultures used for phenotypic characterization carried the appropriate mutation, all cultures were tested after growth for the correct insertion by diagnostic PCR.

In broth culture, the growth rate of the mutants defective in the copy 1 genes in the presence of kanamycin was not significantly different from that of a wild-type strain containing a Km-resistance marker, strain T401 (Fig. 3; Table 2). However, the growth rate of the mutants with insertions in the copy 2 genes was consistently $15-20 \%$ slower than the wild-type or the copy 1 mutants, and longer lag phases were common. Methane-dependent $\mathrm{O}_{2}$ uptake rates were determined in mutant and wildtype strains, as a measure of pMMO activity. Mutants in the copy 1 genes had rates that were $65-85 \%$ of the wild-type rate. However, mutants in copy 2 genes showed lower rates, $37-50 \%$ of the wild-type rate (Table 2).

Attempts were made to generate double mutants in pmoB using both $\mathrm{Km}-$ and $\mathrm{Sm}$-resistance cassettes. A 
Table 2. Doubling time and methane oxidation rates for wild-type and pmo mutants

\begin{tabular}{|lccc|}
\hline Strain & Affected gene & $\begin{array}{c}\text { Doubling time } \\
(\mathbf{h})^{*}\end{array}$ & $\begin{array}{c}\mathrm{CH}_{\mathbf{4}} \text { oxidation [nmol } \\
(\mathbf{m g} \text { protein })^{-1} \mathbf{m i n}^{-1} \text { ] }\end{array}$ \\
\hline T401 (Km' wild-type $)$ & & $7 \cdot 8 \pm 1 \cdot 0$ & 351 \\
MCK60 & pmoC1 & $6 \cdot 6 \pm 2 \cdot 1$ & 299 \\
MCK62 & pmoC2 & $9 \cdot 2 \pm 1 \cdot 3$ & 177 \\
MBK1-1 & pmoB1 & $8 \cdot 0 \pm 0 \cdot 4$ & 232 \\
MBK206 & pmoB2 & $9 \cdot 3 \pm 2 \cdot 1$ & 130 \\
MAK5 & pmoA1 & $5 \cdot 5 \pm 2 \cdot 1$ & 225 \\
MAKF016 & pmoA2 & $8 \cdot 8 \pm 1 \cdot 2$ & 165 \\
\hline
\end{tabular}

* Measurements are means and standard deviations for triplicate cultures grown in the presence of kanamycin.

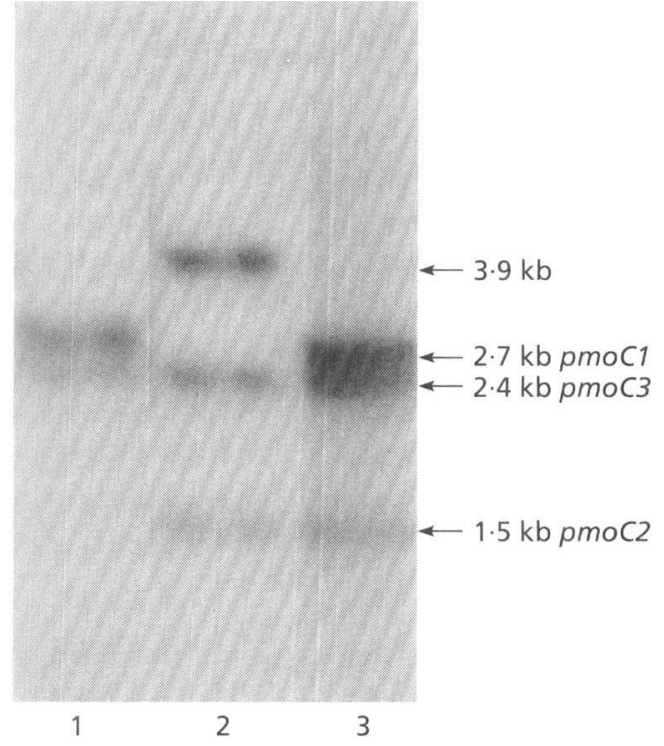

Fig. 4. DNA blot showing hybridization of Sall-digested $M$. capsulatus Bath chromosomal DNA to a pmoC1 probe (the Kpnl-Smal fragment of pAMC101). 1, MCK62 (pmoC2 insertion strain); 2, MCK60 (pmoC1 insertion strain); 3, wild-type.

Sm-resistance cassette was inserted into the MscI site within pmoB2 in pAMC103, and an EcoRI fragment with the disrupted $p m o B 2$ sequence was recloned into the suicide vector pAYC61. The MBK1-1 mutant carrying a $\mathrm{Km}$ insertion in $p m o B 1$ was used as a recipient, and selection was carried out on both NMS and NMSF plates. Although colonies were obtained on both types of media that were resistant to both $\mathrm{Sm}$ and $\mathrm{Km}$, most of them showed decreased growth on plates with each transfer, and were not viable after three to four transfers. Those that were able to grow through multiple transfers were Ap-resistant, suggesting they were single-crossover recombinants containing a complete $p m o B$ gene. Hybridization analysis confirmed the suspected recombination events (data not shown). When the same Sm-resistance construction was used in wildtype, double-crossover recombinants were obtained separately in $p m o B 1$ and $p m o B 2$, demonstrating that the Sm-resistance plasmid was functional for generating insertion mutations. These mutants were also used as recipients for constructions containing $\mathrm{Km}$ insertions into each $p m o B$ gene, and in these cases also, no Apsensitive clones were obtained.

\section{Third copy of pmoC}

As noted above, all of the insertion mutants were analysed by hybridization with probes for the genes that were disrupted and for the Km-resistance cassette. In the case of the $p m o A$ and $p m o B$ mutants, these experiments produced the expected results and confirmed the presence of two copies. However, hybridization of Salldigested $M$. capsulatus Bath chromosomal DNA to a pmoC1 probe (the KpnI-SmaI fragment of pAMC101) revealed three bands of hybridization of $1.5,2.4$ and $2.7 \mathrm{~kb}$ (Fig. 4). Because it was known that neither pmoC1 nor pmoC2 contained a Sall site, these results suggested the presence of a third copy of pmoC in the genome of $M$. capsulatus Bath. This idea was supported by results from hybridization of Sall-digested DNA from the insertion mutants MCK60 and MCK62, which contain a $\mathrm{Km}$-resistance insertion in pmoC1 and pmoC2, respectively. In the pmoC1 mutant, hybridization with the pmoC1 probe showed that the $2.7 \mathrm{~kb}$ band was increased in size about $1.3 \mathrm{~kb}$, as expected for the insertion, while the other two bands remained the same. In the pmoC2 mutant, hybridization with the same probe showed that the $1.5 \mathrm{~kb}$ band increased to about $2.8 \mathrm{~kb}$, as expected, and the other two bands remained the same, although the 2.7 and $2.8 \mathrm{~kb}$ bands were not well resolved (Fig. 4). These results suggested that the $2.4 \mathrm{~kb}$ band contained a third copy of pmoC. Sall-digested chromosomal DNA from the MCK60 mutant (containing an insertion in pmoC1) was hybridized with primers specific for pmoC sequence (CSS16R, CSS17R, CSSK4F, CSS9R and CSS10R) as well as the pmoA-specific primer ASS1F. As expected, all of the primers hybridized to the bands corresponding to copy 1 and copy 2, and most of the pmoC-specific primers hybridized to the $2.4 \mathrm{~kb}$ band containing the putative pmoC3. However, CSS17R and ASS1F did not hybridize 
to the $2.4 \mathrm{~kb}$ Sall fragment or to any new fragments. These results suggested that a third copy of $p m o A$ is not present and that significant divergence of the $p m o C 3$ sequence occurs in the $\mathrm{N}$-terminal region. Therefore, we used an inverse PCR strategy similar to that used for the copy 2 genes to obtain the $\mathrm{N}$-terminal, $\mathrm{C}$-terminal and upstream regions of $p m o C 3$.

Sall-digested DNA from MCK60 was ligated and redigested with AflIII. This DNA was used as a template for PCR with the CSS19R and CSS9F primers. A PCR product of the predicted size was obtained, cloned into pCR2.1 vector and sequenced, providing the sequence of the flanking regions. PCR primers (C3F1 and C3R1, see Methods) were then designed to amplify the whole ORF of pmoC3 and complete the sequence. An ORF of 253 amino acids was identified with high identity to the other copies of $p m o C$ in the central region but containing divergence at the $\mathrm{N}$ - and C-termini (Fig. 2).

The entire ORF for $p m o C 3$ was generated by PCR and cloned into the pCR2.1 vector. However, only plasmids containing pmoC3 in the orientation opposite to the direction of transcription from the pCR2.1 lac promoter were obtained. Attempts were made to generate insertion mutations in pmoC3, using the BbsI site for a $\mathrm{Km}^{\mathrm{r}}$ cassette and the cloned PCR product containing the entire pmoC3. Matings were tested on both NMS plates with copper (for pMMO expression) and NMSF plates (for sMMO expression). However, only single-crossover insertions were obtained, which generated an intact pmoC3. These mutants grew normally on methane.

\section{DISCUSSION}

The results in this report complete the sequence of two sets of $p m o C A B$ genes, and provide the sequence of a third copy of $p m o C$. For the first two sets, the sequences are almost identical within the coding and intergenic regions, but they diverge outside the $p m o C A B$ regions. For pmoC3, the sequence diverges in the $\mathrm{N}$ - and $\mathrm{C}$ terminus of the encoded protein (Fig. 2). The genetic organization and numbers of gene copies for this pmo system are highly similar to those observed for amo genes in Nitrosomonas europaea (Hommes et al., 1998; Sayavedra-Soto et al., 1998), but other nitrifiers have three sets of amo genes (Norton et al., 1996; SayavedraSoto et al., 1998). The role of these multiple gene copies has not been well understood in either methanotrophs or nitrifiers. Methanotrophs such as M. capsulatus Bath have two alternative methane oxidation systems, the pMMO and the sMMO. Therefore, the physiological role of pMMO is different in these methanotrophs from that of ammonia monooxygenase in nitrifiers, since nitrifiers do not contain an alternative ammonia oxidation system.

In this study, double-crossover insertion mutants were isolated for each pmo gene found in the two sets of complete $p m o C A B$ clusters, to assess the contribution of each gene copy to pMMO activity. These mutants all grew on methane in the presence of copper and in the absence of detectable sMMO expression, suggesting that pMMO must be produced from each set of genes under these growth conditions. This conclusion is confirmed by the results of the methane oxidation rate experiments in mutants and wild-type, which showed that about a third of the whole-cell methane oxidation is due to copy 1 genes, while about two-thirds is due to copy 2 genes. The presence of the two copies of pmo genes apparently gives the cells excess methane oxidation capacity, since impairment of the copy 1 genes did not affect growth. However, impairment of the copy 2 genes did result in a small growth defect, suggesting that cells need the copy 2 gene expression for normal growth.

These results are similar in some respects to the results obtained so far for the amo system in nitrifying bacteria. In $N$. europaea, mutants have only been generated in amoA gene copies, so no information is available for $a m o B$ or $a m o C$ mutants. For amo $A$, mutants defective in each gene were viable, but mutants in one copy showed decreased growth while the other mutants showed normal growth (Hommes et al., 1998), similar to the results we report here for $p m o A$ mutants. However, in the nitrifier the whole-cell ammonia oxidation rate did not change significantly in the mutant with normal growth rate, suggesting that under these conditions the wild-type ammonia monooxygenase activity could be sustained by the other gene copy. This is in contrast to our results, in which both copies are required to maintain wild-type pMMO activity.

Since the two clusters of pmo genes are so similar in sequence, it seems likely that the enzymes produced from each copy have a similar function. Therefore, the role of the duplicate gene clusters may be simply to provide increased gene expression, although it appears that this higher level of pMMO activity is not necessary for maximal growth under laboratory conditions. It may be that the two copies are important for different types of growth conditions, for instance under stress conditions that might be encountered in the natural environment. It is also possible that the two copies are differentially expressed under different growth conditions, since the sequences upstream of pmoC1 and $p m o C 2$ are highly divergent. Further work involving promoter identification and expression will be required to resolve these questions.

We have also examined $p m o C 3$, since the role of this separate $p m o C$ gene is unknown and in $M$. capsulatus Bath it has a more divergent sequence than the other two pmoC copies. However, we were unable to isolate a null mutant in pmoC3. We cannot be certain whether this failure is due to an unknown technical problem that caused double-crossover recombination to occur at extremely low frequencies, or whether it is due to the essential nature of pmoC3 under the tested growth conditions. However, since we were able to isolate null mutants in $p m o C 1$ and $p m o C 2$ using a similar procedure and similar constructions, it is likely that pmoC3 null mutants are not viable. Therefore, our results suggest that $p m o C 3$ has an essential function in methane oxidation separate from the function of $p m o C 1$ and 
pmoC2. The role of this separate copy of $p m o C$ is not yet clear, but it probably fulfils a function necessary for generating active pMMO from both pmo clusters. It is unlikely that this function is to provide PmoC for $\mathrm{pMMO}$, since the major transcript from the two clusters contains all three genes ( $p m o C A B)$ and it is likely that all three are translated (Nielsen et al., 1997).

Since $M$. capsulatus Bath contains an alternative methane oxidation system (sMMO), it should be possible to obtain a pMMO-negative strain under conditions in which sMMO is expressed. We developed plate growth conditions that maximized expression of sMMO, and attempted to generate a double mutant that contained double-crossover (null) mutations in both $p m o B$ genes. However, all isolates always contained one wild-type $p m o B$, the result of a single-crossover recombination event. It is unlikely in this case that a technical problem occurred, because null mutants were readily obtained in each $p m o B$ copy individually using both markers. Similar attempts to obtain double mutants in $p m o A$ were also unsuccessful (unpublished data). It is known that $M$. capsulatus Bath can grow quite well in broth culture under conditions in which sMMO is the dominant methane oxidation enzyme, with only a small amount of pMMO present (Prior \& Dalton, 1985a; Zahn \& DiSpirito, 1996). Therefore, it is not clear why null mutants could not be obtained on plates. It is possible that the sMMO levels achieved on plates were too low to allow for growth, although they appeared to be substantial as judged by the colorimetric plate assay. Alternatively, it is possible that low level pMMO expression is required for growth on methane on plates even when sMMO is expressed.

\section{ACKNOWLEDGEMENTS}

This research was supported by a grant from the NSF (MCB9630645) and a University Research Initiative grant from ARPA (N00014-92-J-1901). The plasmid pBR325 $\Omega$ was kindly provided by $\operatorname{Dr}$ J. C. Murrell. We thank Drs L. Chistoserdova, R. Meima and H. Toyama for helpful discussions.

\section{REFERENCES}

Altschul, S. F., Gish, W., Miller, W. \& Myer, E. W. (1990). Basic local alignment search tool. J Mol Biol 215, 403-410.

Altschul, S. F., Madden, T. L., Schaffer, A. A., Zhang, J., Zhang, Z., Miller, W. \& Lipman, D. J. (1997). Gapped BLAST and PSI-BLAST: a new generation of protein database search programs. Nucleic Acids Res 25, 3389-3402.

Bolivar, F. (1978). Construction and characterization of new cloning vehicles. 3. Derivatives of plasmid pBR322 carrying unique EcoRI site for selection. Gene 4, 121-136.

Cardy, D. L. N., Laidler, V., Salmond, G. P. C. \& Murrell, C. J. (1991). Molecular analysis of the methane monooxygenase (MMO) gene cluster of Methylosinus trichosporium OB3b. Mol Microbiol 5, 335-342.

Chistoserdov, A. Y., Mclntire, W. S. \& Lidstrom, M. E. (1994). Genetic organization of the mau gene cluster in Methylobacterium extorquens AM1: complete nucleotide sequence and generation and characterization of mau mutants. J Bacteriol 176, $4052-4065$.

Colby, J. \& Dalton, H. (1976). Some properties of a soluble methane mono-oxygenase from Methylococcus capsulatus strain Bath. Biochem J 157, 495-497.

DiSpirito, A. A., Gulledge, J., Murrell, J. C., Shiemke, A. K., Lidstrom, M. E. \& Krema, C. L. (1992). Trichloroethylene oxidation by the membrane associated methane monooxygenase in type I, type II and type X methanotrophs. Biodegradation 2, 151-164.

Figurski, D. H. \& Helinski, D. R. (1979). Replication of an origincontaining derivative of plasmid RK2 dependent on a plasmid function provided in trans. Proc Natl Acad Sci USA 77, 7347-7357.

Fox, B. G., Froland, W. A., Dege, J. E. \& Lipscomb, J. D. (1989). Methane monooxygenase from Methylosinus trichosporium OB3b. Purification and properties of a three-component system with high specific activity from a type II methanotroph. $J$ Biol Chem 264, 10023-10033.

Graham, D. W., Korich, D. G., LeBlanc, R. P., Sinclair, N. A. \& Arnold, R. G. (1992). Applications of a colorimetric plate assay for soluble methane monooxygenase activity. Appl Environ Microbiol 58, 2231-2236.

Green, J. \& Dalton, H. (1989). Substrate specificity of soluble methane monooxygenase: mechanistic implications. J Biol Chem 264, 17698-17703.

Hanson, R. S., Netrusov, A. I. \& Tsuji, K. (1990). The obligate methanotrophic bacteria Methylococcus, Methylomonas, and Methylosinus. In The Prokaryotes, 2nd edn, pp. 2350-2364. Edited by A. Balows, H. G. Trüper, M. Dworkin, W. Harder \& K.-H. Schleifer. New York: Springer.

Hommes, N. G., Sayavedra-Soto, L. A. \& Arp, D. J. (1998). Mutagenesis and expression of amo, which codes for ammonia monooxygenase in Nitrosomonas europaea. J Bacteriol 180, 3353-3359.

Klotz, M. G., Alzerecca, J. \& Norton, J. M. (1997). A gene encoding protein exists upstream of the $a m o A / a m o B$ genes in ammonia oxidizing bacteria: a third member of the amo operon? FEMS Microbiol Lett 150, 65-73.

Koh, S.-C., Bowman, J. P. \& Sayler, G. S. (1993). Soluble methane monooxygenase production and trichloroethylene degradation by a type I methanotroph, Methylomonas methanica 68-1. Appl Environ Microbiol 59, 960-967.

McDonald, I. R., Uchiyama, H., Kambe, S., Yagi, O. \& Murrell, J. C. (1997). The soluble methane monooxygenase gene cluster of the trichloroethylene degrading methanotroph Methylocystis sp. strain M. Appl Environ Microbiol 63, 1898-1904.

McNerney, T. \& O'Connor, M. L. (1980). Regulation of $C_{1}$ enzymes in three facultative methylotrophs. Appl Environ Microbiol 40, 370-375.

McTavish, H., Fuchs, J. A. \& Hooper, A. B. (1993). Sequence of the gene coding for ammonia monooxygenase in Nitrosomonas europaea. J Bacteriol 175, 2436-2444.

Marmur, J. (1961). A procedure for the isolation of deoxyribonucleic acid from microorganisms. J Mol Biol 3, 208-218.

Martin, H. \& Murrell, J.C. (1995). Methane monooxygenase mutants of Methylosinus trichosporium constructed by markerexchange mutagenesis. FEMS Microbiol Lett 127, 243-248.

Meinkoth, J. \& Wahl, G. (1984). Hybridization of nucleic acids immobilized on a solid support. Anal Biochem 138, 267-284.

Nakajima, T., Uchiyama, H., Yagi, O. \& Nakahara, T. (1992). Purification and properties of a soluble methane monooxygenase 
from Methylocystis sp. M. Biosci Biotechnol Biochem 56, 736-740.

Nguyen, H.-H. A. T., Shiemke, A. K., Jacobs, S. J., Hales, B. J., Lidstrom, M. E. \& Chan, S. I. (1994). The nature of the copper ions in the membranes containing the particulate methane monooxygenase from Methylococcus capsulatus (Bath). J Biol Chem 269, 14995-15005.

Nguyen, H.-H. A. T., Elliot, S. J., Kent, B. H. \& 10 other authors (1996). The biochemistry of the particulate methane monooxygenase. In Microbial Growth on $C_{1}$ Compounds, pp. 150-158. Edited by M. E. Lidstrom \& F. R. Tabita. Dordrecht: Kluwer.

Nguyen, H.-H. A. T., Elliot, S. J., Yip, J. H. K. \& Chan, S. I. (1998). The particulate methane monooxygenase from Metbylococcus capsulatus (Bath) is a novel copper-containing three-subunit enzyme - isolation and characterization. J Biol Chem 272, $7957-7966$.

Nielsen, A. K., Gerdes, K. \& Murrell, J. C. (1997). Copperdependent reciprocal transcriptional regulation of methane monooxygenase genes in Methylococcus capsulatus and Metbylosinus trichosporium. Mol Microbiol 25, 399-409.

Norton, J. M., Jackie, M. L. \& Klotz, M. G. (1996). The gene encoding ammonia monooxygenase subunit $A$ exists in three nearly identical copies in Nitrosospira sp. NpAV. FEMS Microbiol Lett 139, 181-188.

Prentki, P. \& Krisch, H. M. (1984). In vitro insertional mutagenesis with a selectable DNA fragment. Gene 29, 303-313.

Prior, S. D. \& Dalton, H. (1985a). The effect of copper ions on membrane content and methane monooxygenase activity in methanol-grown cells of Methylococcus capsulatus (Bath). J Gen Microbiol 131, 155-163.

Prior, S. D. \& Dalton, H. (1985b). Acetylene as a suicide substrate and active site probe for methane monooxygenase from Methylococcus capsulatus (Bath). FEMS Microbiol Lett 29, 105-109.

Sambrook, J., Fritsch, E. F. \& Maniatis, T. (1989). Molecular Cloning: a Laboratory Manual, 2nd edn. Cold Spring Harbor, NY: Cold Spring Harbor Laboratory.
Sayavedra-Soto, L. A., Hommes, N. G., Alzerreca, J. J., Arp, D. J., Norton, J. M. \& Klotz, M. G. (1998). Transcription of the amoC, amoA and amoB genes in Nitrosomonas europaea and Nitrosospira sp. NpAV. FEMS Microbiol Lett 167, 81-88.

Semrau, J. D., Chistoserdov, A., Lebron, J. \& 7 other authors (1995). Particulate methane monooxygenase genes in methanotrophs. J Bacteriol 177, 3071-3079.

Simon, R., Priefer, U. \& Puhler, A. (1983). A broad host range mobilization system for in vivo genetic engineering: transposon mutagenesis in Gram-negative bacteria. Bio/Technology 1, $37-45$.

Smith, D. D. \& Dalton, H. (1989). Solubilization of methane monooxygenase from Methylococcus capsulatus (Bath). Eur J Biochem 182, 667-671.

Stainthorpe, A. C., Lees, V., Salmond, G. P. C., Dalton, H. \& Murrell, J. C. (1990). The methane monooxygenase gene cluster of Methylococcus capsulatus (Bath). Gene 91, 27-34.

Stolyar, S. M., Romanovskaya, V. A. \& Malashenko, Y. R. (1995). Search for systems of genetic exchange in methane-oxidizing bacteria. Microbiology (English translation of Mikrobiologiya) 64, 584-588.

Vieira, J. \& Messing, J. (1982). The pUC plasmids, an M13mp7derived system for insertion mutagenesis and sequencing with synthetic universal primers. Gene 19, 259-268.

Whittenbury, R. \& Dalton, H. (1981). The methylotrophic bacteria. In The Prokaryotes, pp. 894-902. Edited by M. Starr, H. Stolp, H. Trüper, A. Balows \& H. Schlegel. Berlin: Springer.

Yanisch-Perron, C., Vieira, J. \& Messing, J. (1985). Improved M13 phage cloning vectors and host strains: nucleotide sequences of the M13mp18 and pUC19 vectors. Gene 33, 103-119.

Zahn, J. A. \& DiSpirito, A. A. (1996). Membrane-associated methane monooxygenase from Methylococcus capsulatus (Bath). J Bacteriol 178, 1018-1029.

Received 13 January 1998; accepted 28 January 1999. 


\title{
Expression of the Oenococcus oeni trxA gene is induced by hydrogen peroxide and heat shock
}

\author{
Michel-Philippe Jobin, Dominique Garmyn, Charles Diviès \\ and Jean Guzzo
}

Author for correspondence: Jean Guzzo. Tel: +33 380396675. Fax: +33380396640. e-mail: jguzzo@u-bourgogne.fr

Laboratoire de

Microbiologie, U. A. INRA, ENSBANA, 1 Esplanade Erasme, 21000 Dijon, France

\begin{abstract}
Sequencing of the DNA region located upstream of the $\alpha$-acetolactate synthase and decarboxylase (alsS-alsD) cluster of Oenococcus oeni allowed identification of an ORF, named trxA. This encodes a protein of 104 amino acids very similar to known thioredoxins. The protein encoded by the cloned fragment was able to complement Escherichia coli strains lacking a functional thioredoxin. Considering the results of protein sequence comparisons and complementation experiments, it was concluded that the trx $A$ gene encodes a functional thioredoxin. Studies of trxA expression showed that the abundance of trxA mRNA was similar during all growth stages. A significant increase in trxA mRNA levels was observed in the presence of hydrogen peroxide in the medium or after heat shock. A single transcriptional start site was determined with total RNA isolated from cells subjected or not subjected to oxidative stress or heat shock. In each case the same promoter region was identified and shown to have a high similarity to the consensus promoter sequence of Grampositive bacteria, as well as to that of $E$. coli and the previously mapped promoters from 0 . oeni.
\end{abstract}

Keywords: Oenococcus oeni, thioredoxin, oxidative stress, heat shock

\section{INTRODUCTION}

Thioredoxins have been isolated and characterized from many micro-organisms, plants and animals (Holmgren, 1985). Such proteins are involved in a wide variety of biochemical processes in living cells. Reduced thioredoxin serves as an efficient hydrogen donor for many reductase enzymes and protein disulfide isomerases (Holmgren, 1989). The active site of thioredoxin (TrpCys-Gly-Pro-Cys) is highly conserved and contains two redox-active cysteine residues, which form either a disulfide (oxidized form) or a dithiol (reduced form). The $S-S$ bond of oxidized thioredoxin is reduced by NADPH and a specific enzyme called thioredoxin reductase (Moore et al., 1964).

Thioredoxin appears to be an essential protein for many organisms, such as Bacillus subtilis (Scharf et al., 1998), Synechocystis (Navarro \& Florencio, 1996) and Rhodobacter sphaeroides (Pasternak et al., 1997), in contrast to

The GenBank accession number for the sequence reported in this paper is XT93091.
Escherichia coli (Holmgren et al., 1978). A variety of stresses, including heat, salt stress or ethanol treatment, strongly enhance the synthesis of thioredoxin in $B$. subtilis (Scharf et al., 1998). In this species, a double control of stress induction at two different promoters has been demonstrated: the first promoter is $\sigma^{\mathrm{B}}$. dependant, whilst the second is presumably $\sigma^{\mathrm{A}}$-dependant and might require activation by some other unknown mechanism.

Oenococcus oeni is a lactic acid bacterium which is able to grow in wine and to perform the malolactic fermentation (Dicks et al., 1995; Kunkee, 1967; Labarre et al., 1996a). No information is available on thioredoxin synthesis and activity in this heterofermentative bacterium. In the course of our investigations on the stress response of $\mathrm{O}$. oeni, we previously studied an $18 \mathrm{kDa}$ small heat-shock protein (Lo18), highly induced by multiple stresses such as heat shock, acid shock, the presence of ethanol or sulfite, and in stationary phase (Guzzo et al., 1997, 1998). The hsp18 gene encoding this protein was cloned and characterized (Jobin et al., 1997). After purification of the protein, it was shown that Lo18 could form oligomers and prevent citrate 
synthase from thermal aggregation (F. Delmas, personal communication).

We report here the nucleotide sequence of a chromosomal DNA fragment encoding the thioredoxin of $O$. oeni. The size of the transcript and the transcriptional start site were determined and the expression of the gene in response to oxidative and heat stresses was investigated.

\section{METHODS}

Bacterial strains, plasmids and media. The strains and plasmids used in this study are listed in Table 1. E. coli strains were grown in Luria-Bertani (LB) broth or LB agar at $37^{\circ} \mathrm{C}$. In the selective medium the antibiotic erythromycin was used at a concentration of $200 \mu \mathrm{g} \mathrm{m}^{-1}$. O. oeni strain Lo84.13 was grown at $30^{\circ} \mathrm{C}$ in FT80 medium (pH 5.3) (Cavin et al., 1989), modified by adding meat extract $\left(5 \mathrm{~g} \mathrm{l}^{-1}\right)$ instead of Casamino acids.

DNA manipulations, sequencing and analysis. Molecular techniques were carried out using standard methods (Sambrook et al., 1989). Double-stranded plasmid DNA was purified with a Qiagen plasmid kit and sequenced using the dideoxy chain-termination method (Sanger et al., 1977). Computer analyses of nucleotide and amino acid sequences were carried out with the BLAST (Altschul et al., 1990) and CLUSTAL w programs (Higgins et al., 1994).

Isolation of total RNA and Northern blot analysis. O. oeni total RNA was purified as previously described (Labarre $e$ t al., 1996b) from control cells (grown at $30^{\circ} \mathrm{C}$ ), or cultivated in the

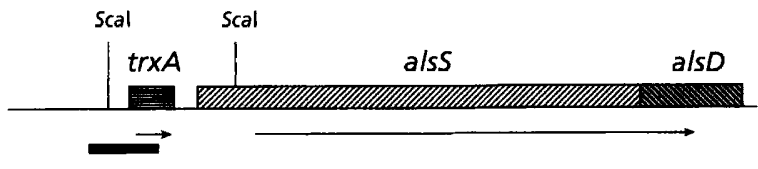

Fig. 1. 0 . oeni trxA-alsSD cluster. The positions of $\operatorname{trx} A$, alsS and $a / s D$ are indicated by boxes. The direction of transcription is indicated by arrows. Scal restriction sites are shown. The probe used for Northern blotting is indicated by the bold line below the map.

presence of hydrogen peroxide $\left(10 \mathrm{mg} \mathrm{l}^{-1}\right)$, or after addition of hydrogen peroxide $\left(8-20 \mathrm{mg} \mathrm{l}^{-1}\right)$ for 30 or $60 \mathrm{~min}$, or submitted to heat shock for 5-30 min. RNA $(30 \mu \mathrm{g})$ was separated in a $1.2 \%(\mathrm{w} / \mathrm{v})$ agarose $/ 6.6 \%(\mathrm{v} / \mathrm{v})$ formaldehyde gel and then transferred to Hybond- $\mathrm{N}+$ membranes (Amersham). The $\operatorname{tr} x A$ probe (Fig. 1) was radiolabelled with $\left[\alpha-{ }^{32} \mathrm{P}\right] \mathrm{dATP}$, using a Random Primer DNA Labelling System (Gibco-BRL). All the Northern blot analyses were repeated at least twice.

Primer extension analysis. Oligonucleotides (TRX1, 5'-CCG GAT TTG GTT GCT TCC TC-3'; TRX2, 5'-TCA GTC ACA GTC ACG CCG GA-3' ; and TRX3, 5'-TTG CCG AAT TTA ACC CTC GA-3') were used to map the $5^{\prime}$ terminus of $\operatorname{tr} x A$ mRNA in O. oeni. Total RNA $(5 \mu \mathrm{g})$ was mixed with 2 pmol of each primer. After a 5 min denaturation step at $100^{\circ} \mathrm{C}$, the mixture was cooled in ice for annealing. Reverse transcription was carried out as recommended by the manufacturer with the Superscript II RNase $\mathrm{H}^{-}$Reverse Transcriptase (Gibco-BRL). Analysis of the extension products was performed as previously described (Jobin et al., 1997).

Table 1. Bacterial strains and plasmids used in this study

\begin{tabular}{|c|c|c|}
\hline $\begin{array}{l}\text { Strain or } \\
\text { plasmid }\end{array}$ & Genotype or phenotype & Source or reference \\
\hline \multicolumn{3}{|l|}{ Strains } \\
\hline \multicolumn{3}{|l|}{ O. oeni } \\
\hline Lo84.13 & $\mathrm{MLE}^{+}$ & $\begin{array}{l}\text { Oenological Institute } \\
\text { of Bordeaux }\end{array}$ \\
\hline \multicolumn{3}{|l|}{ E. coli } \\
\hline TG1 & $\begin{array}{l}\text { supE hsd } \Delta 5 \text { thi } \Delta\left(\text { lac-proAB) } \mathrm{F}^{\prime}(\text { traD } 36\right. \\
\left.\text { pro } A^{+} B^{+} \text {lacl }^{\mathrm{q}} \text { lacZ } \Delta \mathrm{M} 15\right)\end{array}$ & Gibson (1984) \\
\hline AR1062 & $\begin{array}{l}\mathrm{F}^{-} \text {thr leu ara azi fhuA lacY tsx minA gal } \\
\text { rspL } x y l \text { mtl thi bsdR }\end{array}$ & D'Enfert et al. (1987) \\
\hline BH2012 & $\begin{array}{l}\mathrm{F}^{-} \text {araD139? galU galK bsdR rpsL metE46 } \\
\text { argH1 trxA2 iluC::Tn5 }\end{array}$ & Lim et al. (1985) \\
\hline A.312 & met $E:: \operatorname{Tn} 10$ & Russel \& Model (1986) \\
\hline A313 & $\operatorname{tr} x A:: k a n$ metE:: $\operatorname{Tn} 10$ & Russel \& Model (1986) \\
\hline \multicolumn{3}{|l|}{ Plasmids } \\
\hline pGID023 & $\begin{array}{l}\text { Shuttle vector for E. coli and L. plantarum, } \\
\text { derivative of pJDC9 containing pE194 } \\
\text { replication functions; } \mathrm{Em}^{\mathrm{R}}\end{array}$ & Hols et al. (1994) \\
\hline pGID600 & $\begin{array}{l}\text { pJDC9 containing a } 7 \mathrm{kbp} \text { Sau3A fragment } \\
\text { from } 0 \text {. oeni DNA }\end{array}$ & Garmyn et al. (1996) \\
\hline pGID608 & $\begin{array}{l}\text { pGID } 023 \text { containing a } 863 \text { bp Scal fragment } \\
\text { from pGID } 600\end{array}$ & This study \\
\hline
\end{tabular}




\section{RESULTS}

\section{Nucleotide sequence of trxA}

In a previous publication, we reported the isolation of a recombinant clone (pGID600) carrying the O. oeni alsSD cluster (Fig. 1) and the corresponding nucleotide sequence (Garmyn et al., 1996). We found an ORF in the same orientation as alsSD that terminated $115 \mathrm{bp}$ upstream of alsSD. We have now determined the nucleotide sequence upstream of this region by primerwalking using pGID600 as a template. An ORF of 104 codons is preceded by a putative ribosome-binding site (AAGGAGG) complementary to the sequence $3^{\prime}$ UUUCCUCCA (complementary bases underlined) at the 3' end of Leuconostoc mesenteroides 16S rRNA (Yang \& Woese, 1989). L. mesenteroides was taken as reference because the $3^{\prime}$ end of O. oeni $16 \mathrm{~S}$ rRNA has not been determined, and it is known that the sequence is conserved at the $3^{\prime}$ ends of different Gram-positive bacteria (Chassy \& Murphy, 1993). Furthermore, the genus Leuconostoc is closely related to Oenococcus (Dicks et al., 1995). Inspection of the 3' noncoding sequence showed an inverted repeat sequence that could form a stem-and-loop structure in mRNA with a calculated $\Delta G_{\mathrm{f}}$ of $-68 \mathrm{~kJ} \mathrm{~mol}^{-1}$. The deduced primary structure of the encoded TrxA is composed of 104 amino acids, with a predicted molecular mass of $11.5 \mathrm{kDa}$. The $O$. oeni TrxA exhibits sequence similarity to other bacterial TrxA (Fig. 2), with a particularity high sequence identity (48\%) to B. subtilis (Chen et al., 1989). The primary structure of $O$. oeni thioredoxin revealed the presence of a typical active centre. However, the sequence between the two vicinal Cys residues was different from that found in most thioredoxins, with the Gly residue replaced by a Thr residue.

\section{Expression in $E$. coli of the $O$. oeni trxA gene}

The predicted amino acid sequence provided strong evidence that the cloned DNA contained the trxA gene encoding the thioredoxin of $O$. oeni. To identify the $\operatorname{trx} A$ gene product, we used an E. coli minicell system which allowed specific labelling of plasmid-encoded proteins (D'Enfert et al., 1987). The 863 bp Scal DNA fragment of pGID600 (Fig. 1) was subcloned in pGID023. Minicells were prepared from E. coli AR 1062, which was transformed with plasmid pGID023 and pGID608. Proteins were labelled with $\left.\mathrm{L}-{ }^{[35} \mathrm{S}\right]$ methionine and analysed by SDS-PAGE (Labarre et al., 1996a). Minicells carrying pGID608 expressed a protein that had a molecular mass of almost $12 \mathrm{kDa}$ (data not shown). This apparent molecular mass is consistent with the calculated value deduced from the nucleotide sequence.

An in vivo assay for thioredoxin function was used to test whether the O. oeni $\mathrm{TrxA}$ protein can substitute for E. coli thioredoxin. E. coli contains the enzyme methionine sulfoxide reductase, which uses thioredoxin as a source of reducing power and thereby enables methionine-requiring strains to utilize methionine sulfoxide for growth (Russel \& Model, 1986). Two different mutant strains, BH2012 and A313, with phenotype

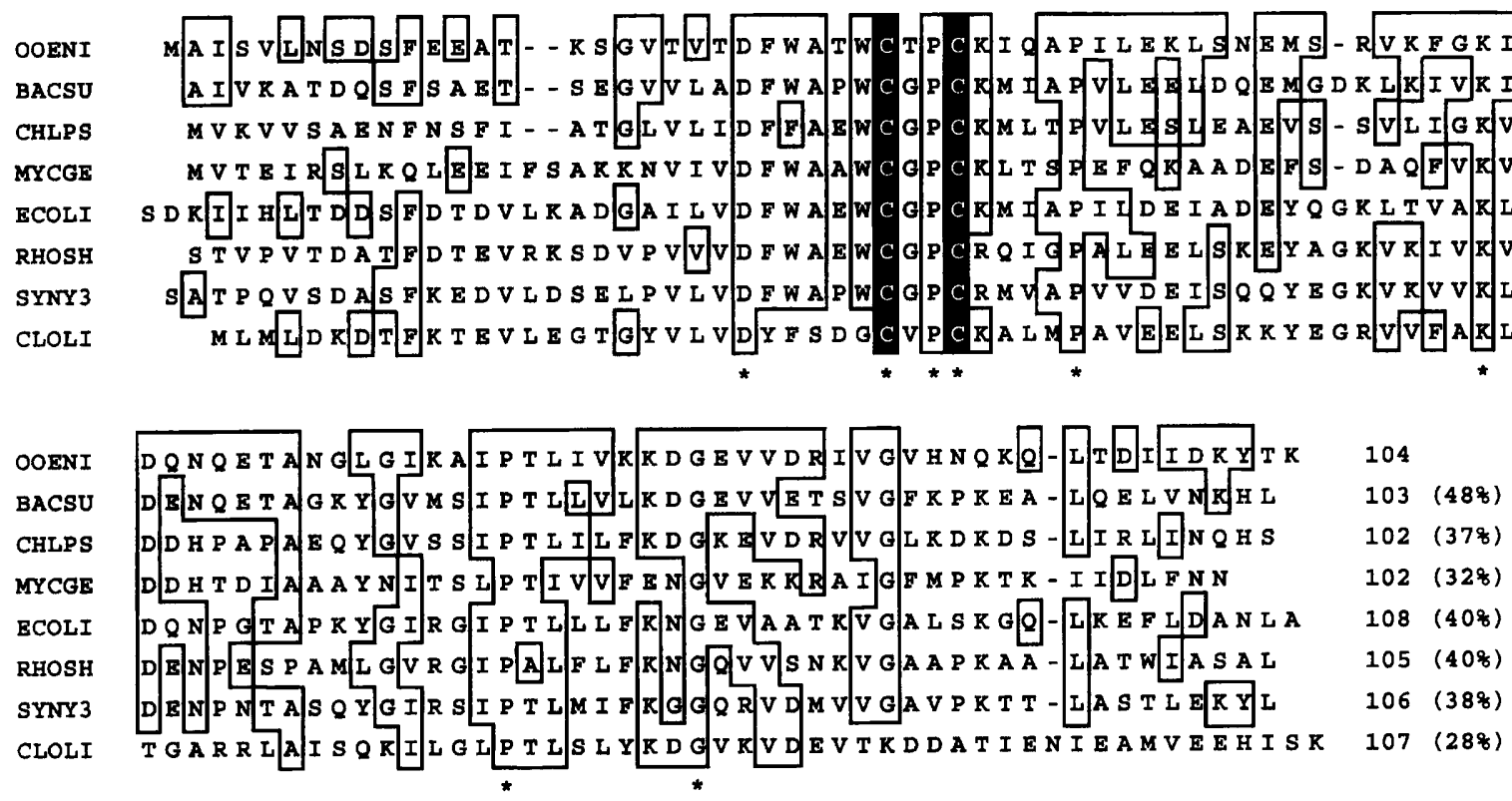

Fig. 2. Comparison of the predicted amino acid sequence of $O$. oeni TrxA (OOENI) with those of TrxA from $B$. subtilis (BACSU) (Chen et al., 1989), Chlamydia psittaci (CHLPS) (Rockey et al., 1996), Mycoplasma genitalium (MYCGE) (Fraser et al., 1995), E. coli (ECOLI) (Lim et al., 1985), R. sphaeroides (RHOSH) (Pille et al., 1990), Synechocystis sp. (SYNY3) (Kaneko et al., 1995) and Clostridium litorale (CLOLI) (Kreimer \& Andreesen, 1995). Amino acids identical to those of O. oeni TrxA are boxed. Asterisks indicate residues that are identical in all sequences. Black boxes indicate redox-active cysteines. Numbers on the right indicate the position of the last amino acid. Percentages in parentheses indicate the identity scores between TrxA from $O$. oeni and from other bacterial species. 


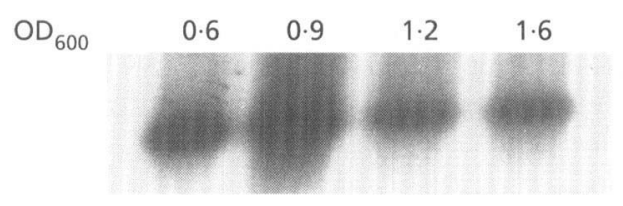

Fig. 3. Detection of trxA mRNA as a function of growth stage. RNA samples were taken from cells during exponential phase $\left(O D_{600} 0.6\right.$ and 0.9$)$, at the beginning of stationary phase $\left(O D_{600}\right.$ $1 \cdot 2)$ and during stationary phase $\left(\mathrm{OD}_{600} 1 \cdot 6\right)$.

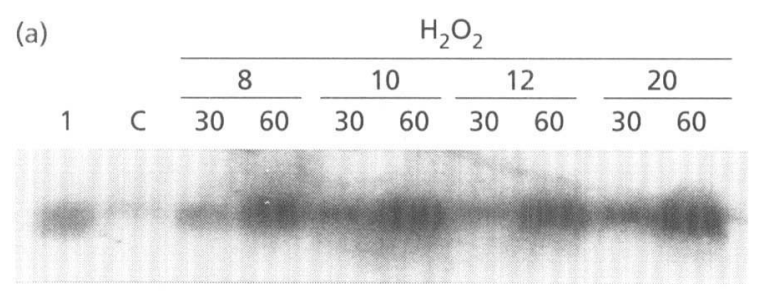

(b)

\begin{tabular}{cccccc} 
& \multicolumn{6}{c}{$4{ }^{\circ} \mathrm{C}$} \\
\cline { 2 - 6 } C & 5 & 10 & 15 & 30 & 60
\end{tabular}

Fig. 4. Northern blot analysis of stress-induced trxA expression. (a) Effect of oxidative stress. RNA samples were isolated from exponentially growing $O$. oeni cells growing in the presence (lane 1) or absence (lane C) of a sublethal dose of hydrogen peroxide $\left(10 \mathrm{mg} \mathrm{l}^{-1}\right)$. In the adjacent lanes, cells in exponential phase were submitted to treatment for 30 or $60 \mathrm{~min}$ with various doses $\left(8,10,12\right.$ and $\left.20 \mathrm{mg}^{-1}\right)$ of hydrogen peroxide, as indicated. (b) Effect of heat shock. RNA samples were isolated from $O$. oeni cells grown at $30^{\circ} \mathrm{C}$ (lane $\mathrm{C}$ ) or from heat-shocked cells at $42^{\circ} \mathrm{C}$. For heat-shocked cells, samples were submitted to a rapid temperature shift (less than $2 \mathrm{~min}$ ). The end of the shift was considered as the start of heat shock, and cells were withdrawn at the time points (in minutes) indicated.

Met $^{-} \operatorname{TrxA}^{-}$and harbouring pGID023 were unable to use methionine sulfoxide to satisfy their methionine requirement. The control strain A312 ( $\mathrm{Met}^{-} \mathrm{TrxA}^{+}$) harbouring pGID023, and both strains BH2012 and A313, carrying the recombinant plasmid pGID608 promoting O. oeni $\operatorname{TrxA}$ synthesis, grew equally well on minimal plates supplemented with L-methionine sulfoxide or L-methionine. This indicated that $O$. oeni thioredoxin serves as a cofactor for $E$. coli methionine sulfoxide reductase in vivo.

\section{Transcription analysis of the trxA gene}

Total RNA was isolated and used to prepare Northern blots from samples taken during exponential phase $\left(\mathrm{OD}_{600} 0.6\right.$ and 0.9$)$, at the beginning of stationary phase $\left(\mathrm{OD}_{600} 1 \cdot 2\right)$ and during stationary phase $\left(\mathrm{OD}_{600} 1 \cdot 6\right)$. These samples were hybridized with the trxA probe which corresponds to the $550 \mathrm{~kb}$ fragment containing part of the trxA gene. Autoradiograms (Fig. 3) showed a single $0.7 \mathrm{~kb}$ transcript hybridizing with the probe. $t r x A$

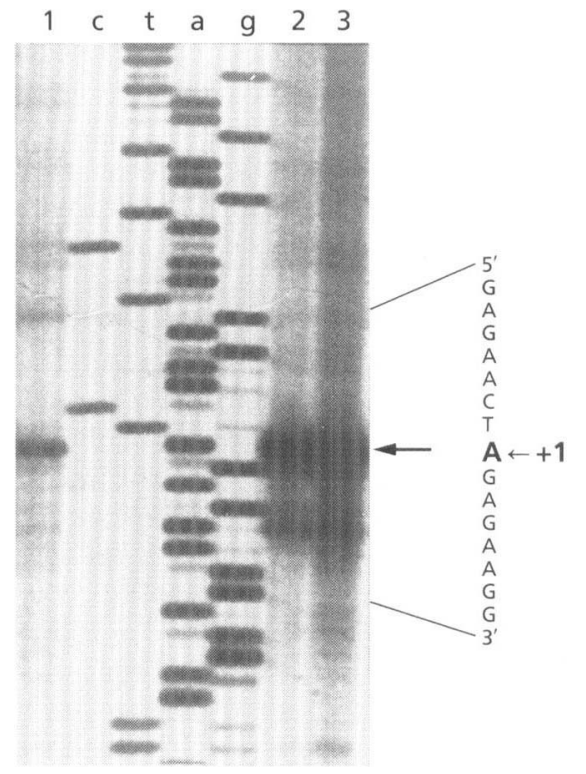

Fig. 5. Mapping of the $5^{\prime}$ end of trxA mRNA by primer extension. Equal amounts of RNA isolated before (lane 1) and $60 \mathrm{~min}$ after (lane 2) the addition of hydrogen peroxide $\left(10 \mathrm{mg} \mathrm{l}^{-1}\right)$, and $15 \mathrm{~min}$ after heat shock (lane 3) were hybridized with primers complementary to the $5^{\prime}$ region of trxA (see Methods). The extension products obtained with primer TRX3 for each RNA sample were electrophoresed in parallel with the sequencing products $(g, a, t$ and $c)$ obtained with the same labelled primer on a sequencing gel. The arrow indicates the position of the deduced start site.

mRNA was detected at a significant level and was estimated to be at roughly the same level during every growth stage, except in late-exponential phase where the transcript appeared at a higher level.

To investigate the effect of oxidative stress, O. oeni cells were cultivated in the presence of a sublethal dose of hydrogen peroxide $\left(10 \mathrm{mg} \mathrm{l}^{-1}\right)$. When the exponential phase was reached, cells were withdrawn and total RNA prepared as described in Methods. Under these growth conditions, a higher level of $\operatorname{tr} x A$ mRNA was detected in comparison to the control (Fig. $4 \mathrm{a}$, compare lanes 1 and C). Moreover, treatment of exponential cells with hydrogen peroxide at various concentrations (8$20 \mathrm{mg} \mathrm{l}^{-1}$ ) for 30 or 60 min significantly enhanced the amount of mRNA detected. The maximum rate of induction was achieved after $60 \mathrm{~min}$ of incubation in the presence of hydrogen peroxide at every concentration tested. No significant increase in the signal was observed at longer incubation times.

In order to examine the effect of temperature increase on $\operatorname{tr} x A$ expression, Northern blot experiments were performed with total RNA extracted from cells submitted to heat shock. The amount of $\operatorname{tr} x A$ messenger was enhanced $5 \mathrm{~min}$ after temperature shift from $30^{\circ} \mathrm{C}$ to $42{ }^{\circ} \mathrm{C}$ and reached a high level of induction after $30 \mathrm{~min}$ of heat shock (Fig. 4b). This temperature induction suggested that the product of $O$. oeni $\operatorname{trx} A$ is a heatshock protein. 
To map the transcription initiation site of the $\operatorname{tr} x A$ gene, nested oligonucleotides TRX1, TRX2 and TRX3 (see Methods) were used in a primer extension assay. RNA samples were extracted from $O$. oeni cells in exponential phase as controls, after addition of hydrogen peroxide (10 $\mathrm{mg} \mathrm{l}^{-1}$ for $\left.60 \mathrm{~min}\right)$ and after heat shock $\left(42{ }^{\circ} \mathrm{C}\right.$ for 15 min). In all culture conditions, a single signal was obtained with oligonucleotides TRX1, TRX2 and TRX3 (Fig. 5), allowing the location of the $5^{\prime}$ end of trxA mRNA 17 nucleotides upstream of the initiation codon. This transcription start point allowed the identification of the promoter for trxA as TTGCAT-17 bpTACAAT. This sequence shows close similarity to the consensus found in the housekeeping promoter of Grampositive bacteria as well as in E. coli (Graves \& Rabinowitz, 1986) and other O. oeni promoters mapped previously (Jobin et al., 1997; Labarre et al., 1996b).

\section{DISCUSSION}

This report presents the DNA sequence, characterization and mRNA analysis of the $\operatorname{trx} A$ gene of $O$. oeni. The primary sequence of the deduced protein revealed that TrxA has significant identity to a number of proteins belonging to the large family of thioredoxins, and in particular to TrxA from B. subtilis ( $48 \%$ identity) (Chen et al., 1989), and that the Cys residues involved in catalysis are conserved. The C-X-X-C motif is critical in determining the exceptional reducing power of disulfide reductase (Konz et al., 1998). Site-directed mutagenesis experiments showed that change of these two central residues can modulate the reducing power of DsbA, a member of the thioredoxin family (Grauschopf et al., 1995). It has recently been reported that thioredoxin from anaerobic, amino-acid-utilizing bacteria possesses a modified consensus sequence at the active centre (Harms et al., 1998). The thioredoxin of such bacteria did not react with thioredoxin reductase of E. coli and the authors suggested that these thioredoxins might form an evolutionarily separate group. One of the two amino acids between the cysteine residues is not conserved in $\mathrm{O}$. oeni $\operatorname{TrxA}$, in which a Thr residue is substituted for the highly conserved Gly residue. This substitution may alter the reducing power of the enzyme. Nevertheless, the protein encoded by the O. oeni trxA gene was able to complement E. coli mutant strains defective in thioredoxin activity. Taken together, these results led us to conclude that the $O$. oeni $\operatorname{tr} x A$ gene encodes a functional thioredoxin.

Few transcriptional analyses of $\operatorname{trx} A$ bacterial genes have been reported so far. The only well-documented example concerns the trxA gene from B. subtilis (Scharf et al., 1998). A variety of stresses, including heat and hydrogen peroxide, strongly enhanced the synthesis of thioredoxin in this bacterium. Transcription initiation of the monocistronic trx $A$ gene occurs at two promoters with different profiles of induction in response to stress. One of these promoters is recognized by the RNA polymerase associated with an alternative $\sigma^{\mathrm{B}}$ factor (Hecker \& Völker, 1998). In Streptomyces coelicolor, the alternative sigma factor $\sigma^{\mathrm{R}}$ modulates expression of the $\operatorname{tr} x B A$ operon, encoding thioredoxin reductase and thioredoxin, in response to oxidative stress (Paget et al. 1998).

The detection of an approximately equal level of $\operatorname{tr} x A$ mRNA in growing cells and during stationary phase suggests that trxA expression is not growth-phase regulated. The level of $\operatorname{tr} x A \mathrm{mRNA}$ is strongly increased by hydrogen peroxide, indicating that thioredoxin is involved in response to oxidative stress, as in many other organisms (Fernando et al., 1992; Kuge \& Jones, 1994; Scharf et al., 1998; Wieles et al., 1997) whereas the E. coli and Salmonella typhimurium trxA genes are not known to be regulated (Farr \& Kogoma, 1991). In addition to oxidative stress, $O$. oeni trx $A$ is also induced by heat shock as is also the case in B. subtilis (Scharf et al., 1998) and in human cells (Jacquier-Sarlin \& Polla, 1996).

The $5^{\prime}$ end of the $\operatorname{tr} x A$ monocistronic transcript was identified in normal growth conditions and allowed us to identify a promoter with a consensus sequence typical for Gram-positive bacteria as well as for E. coli (Graves \& Rabinowitz, 1986). An identical transcription initiation site was obtained with total RNA extracted from cells submitted to oxidative or heat stress. This result suggests that the same potential -35 and -10 regions are recognized by RNA polymerase in all growth conditions tested. During recent work in B. subtilis, at least four different classes of heat-inducible genes were distinguished. The genes of class I are controlled by a repressor which recognizes the CIRCE (controlling inverted repeat of chaperone expression) element (Hecker et al., 1996). Class II genes are positively controlled by the alternative $\sigma^{\mathrm{B}}$ factor (Hecker \& Völker, 1998). Recently, CtsR, a novel regulator of stress and heat shock response, has been shown to act as a repressor of stress genes belonging to class III (Derré $e t$ al., 1999) and those of class IV are regulated by a still unknown mechanism. In lactic acid bacteria, heat-shock genes sharing characteristics of class I (Eaton et al., 1993; Van Asseldonk et al., 1993) and class III (Derré et al., 1999) from B. subtilis have been reported. No CIRCE element was present in the vicinity of the O. oeni $\operatorname{tr} x A$ start site of transcription. To our knowledge, no stress gene expressed under an unusual promoter sequence that may involve an alternative sigma factor has been reported so far in lactic acid bacteria. Moreover, the target consensus sequence corresponding to CtsR was not found in the promoter region of O. oeni trxA. Therefore, the induction of $O$. oeni trx $A$ expression observed after heat or oxidative stresses may require another unknown regulator element, as has been suggested for the heat-shock genes belonging to class IV from B. subtilis.

\section{ACKNOWLEDGEMENTS}

We thank M. Russel and J. Fuchs for providing E. coli strains A312, A313 and BH2012. This work was supported by the Conseil Régional de Bourgogne. 


\section{REFERENCES}

Altschul, S. F., Gish, W., Miller, W., Myers, E. W. \& Lipman, D. J. (1990). Basic local alignment search tool. J Mol Biol 215, 403-410.

Cavin, J. F., Prevost, H., Lin, J., Schmitt, P. \& Diviès, C. (1989). Medium for screening Leuconostoc oenos strains defective in malolactic fermentation. Appl Environ Microbiol 55, 751-753.

Chassy, B. M. \& Murphy, C. M. (1993). Lactococcus and Lactobacillus. In Bacillus subtilis and Other Gram-positive Bacteria: Biochemistry, Physiology, and Molecular Genetics, pp. 65-82. Edited by A. L. Sonenshein, J. A. Hoch \& R. Losick. Washington, DC: American Society for Microbiology.

Chen, N. Y., Zhang, J. J. \& Paulus, H. (1989). Chromosomal location of the Bacillus subtilis aspartokinase II gene and nucleotide sequence of the adjacent genes homologous to $u v r C$ and trx of Escherichia coli. J Gen Microbiol 135, 2931-2940.

D'Enfert, C., Ryter, A. \& Pugsley, A. (1987). Cloning and expression in Escherichia coli of the Klebsiella pneumoniae genes for the production, surface localization and secretion of the lipoprotein pullulanase. $E M B O \mathrm{~J}$ 6, 3531-3538.

Derré, I., Rapoport, G. \& Msadek, T. (1999). CtsR, a novel regulator of stress and heat shock response, controls $c l p$ gene expression in Gram-positive bacteria. Mol Microbiol 31, 117-132.

Dicks, L. M. T., Dellaglio, F. \& Collins, M. D. (1995). Proposal to reclassify Leuconostoc oenos as Oenococcus oeni [corrig.] gen. nov., comb. nov. Int J Syst Bacteriol 45, 395-397.

Eaton, T., Sherman, C. \& Gasson, M. (1993). Cloning and sequence analysis of the dnaK gene region of Lactococcus lactis subsp. lactis. J Gen Microbiol 139, 3253-3264.

Farr, S. B. \& Kogoma, T. (1991). Oxidative stress responses in Escherichia coli and Salmonella typhimurium. Microbiol Rev 55, 561-585.

Fernando, M. R., Nanri, H., Yoshitake, S., Nagato-Kuno, K. \& Minakami, S. (1992). Thioredoxin regenerates proteins inactivated by oxidative stress in endothelial cells. Eur I Biochem 209, 917-922.

Fraser, C. M., Gocayne, J. D., White, O. \& 22 other authors (1995). The minimal gene complement of Mycoplasma genitalium. Science 270, 397-403.

Garmyn, D., Monnet, C., Martineau, B., Guzzo, J., Cavin, J.-F. \& Divies, C. (1996). Cloning and sequencing of the gene encoding $\alpha$ acetolactate decarboxylase from Leuconostoc oenos. FEMS Microbiol Lett 145, 445-450.

Gibson, T. J. (1984). Studies on the Epstein-Barr virus genome. $\mathrm{PhD}$ thesis, University of Cambridge.

Grauschopf, U., Winther, J. R., Korber, P., Zander, T., Dallinger, P. \& Bardwell, J.C.A. (1995). Why is DsbA such an oxidizing disulfide catalyst? Cell $\mathbf{8 3}, \mathbf{9 4 7 - 9 5 5 . ~}$

Graves, M. C. \& Rabinowitz, J. C. (1986). In vivo and in vitro transcription of the Clostridium pasteurianum ferredoxin gene. I Biol Chem 261, 11409-11415.

Guzzo, J., Delmas, F., Pierre, F., Jobin, M.-P., Samyn, B., Van Beeumen, J., Cavin, J.-F. \& Diviès, C. (1997). A small heat shock protein from Leuconostoc oenos induced by multiple stresses and during stationary growth phase. Lett Appl Microbiol 24, 393-396.

Guzzo, J., Jobin, M.-P. \& Diviès, C. (1998). Increase of sulfite tolerance in Oenococcus oeni by means of acidic adaptation. FEMS Microbiol Lett 160, 43-47.

Harms, C., Meyer, M. A. \& Andreesen, J. R. (1998). Fast purification of thioredoxin reductase and of thioredoxins with an unsual redox-active centre from anaerobic, amino-acid-utilizing bacteria. Microbiology 144, 793-800.
Hecker, M. \& Völker, U. (1998). Non-specific, general and multiple stress resistance of growth-restricted Bacillus subtilis cells by the expression of the sigma B regulon. Mol Microbiol 29, 1129-1136. Hecker, M., Schumann, W. \& Völker, U. (1996). Heat-shock and general stress response in Bacillus subtilis. Mol Microbiol 19, $417-428$.

Higgins, D., Thompson, J., Gibson, T., Thompson, J. D., Higgins, D. G. \& Gibson, J. J. (1994). CLUSTAL w : improving the sensibility of progressive multiple sequence alignment through sequence weighting, positive-specific gap penalties and weight matrix choice. Nucleic Acids Res 22, 4673-4680.

Holmgren, A. (1985). Thioredoxin. Annu Rev Biochem 54, 237-271.

Holmgren, A. (1989). Thioredoxin and glutaredoxin systems. J Biol Chem 264, 13963-13966.

Holmgren, A., Ohlsson, I. \& Grakvist, M.-L. (1978). The thioredoxin from Escherichia coli. Radioimmunological and enzymatic determinations in wild type cells and mutants defective in phage T7 DNA replication. J Biol Chem 253, 430-436.

Hols, P., Ferain, T., Garmyn, D., Bernard, N. \& Delcour, J. (1994). Use of homologous expression-secretion signals and vector-free stable chromosomal integration in engineering of Lactobacillus plantarum for $\alpha$-amylase and levanase expression. Appl Environ Microbiol 60, 1401-1413.

Jacquier-Sarlin, M. R. \& Polla, B. S. (1996). Dual regulation of heat-shock transcription factor (HSF) activation and DNAbinding activity by $\mathrm{H}_{2} \mathrm{O}_{2}$ : role of thioredoxin. Biochem $J 318$, 187-193.

Jobin, M.-P., Delmas, F., Garmyn, D., Diviès, C. \& Guzzo, J. (1997). Molecular characterization of the gene encoding an 18-kilodalton small heat shock protein associated with the membrane of Leuconostoc oenos. Appl Environ Microbiol 63, 609-614.

Kaneko, T., Tanaka, A., Sato, S., Kotani, H., Sazuka, T., Miyajima, N., Sugiura, M. \& Tabata, S. (1995). Sequence analysis of the genome of the unicellular cyanobacterium Synechocystis sp. strain PCC6803. I. Sequence features in the $1 \mathrm{Mb}$ region from map positions $64 \%$ to $92 \%$ of the genome. DNA Res $2,153-166$

Konz, J. O., King, J. \& Cooney, C. L. (1998). Effects of oxygen on recombinant protein expression. Biotechnol Prog 14, 393-409.

Kreimer, S. \& Andreesen, J. R. (1995). Glycine reductase of Clostridium litorale. Cloning, sequencing, and molecular analysis of the $\operatorname{grdAB}$ operon that contains two in-frame TGA codons for selenium incorporation. Eur J Biochem 234, 192-199.

Kuge, S. \& Jones, N. (1994). YAP1 dependent activation of TRX2 is essential for the response of Saccharomyces cerevisiae to oxidative stress by hydroperoxides. EMBO J 13, 655-664.

Kunkee, R. E. (1967). Malolactic fermentation. Adv Appl Microbiol 9, 235-279.

Labarre, C., Guzzo, J., Cavin, J. F. \& Diviès, C. (1996a). Cloning and characterization of the genes encoding the malolactic enzyme and the malate permease of Leuconostoc oenos. Appl Environ Microbiol 62, 1274-1282.

Labarre, C., Diviès, C. \& Guzzo, J. (1996b). Genetic organization of the mle locus and identification of a mleR-like gene from Leuconostoc oenos. Appl Environ Microbiol 62, 4493-4498.

Lim, C. J., Geraghty, D. \& Fuchs, J. A. (1985). Cloning and nucleotide sequence of the trxA gene of Escherichia coli $\mathrm{K}-12 . J$ Bacteriol 163, 311-316.

Moore, E. C., Reichard, P. \& Thelander, L. (1964). Enzymatic synthesis of deoxynucleotides. V. Purification and properties of thioredoxin reductase from Escherichia coli B. J Biol Chem 239, 3445-3453. 
Navarro, F. \& Florencio, F. J. (1996). The cyanobacterial thioredoxin gene is required for photoautotrophic and heterotrophic growth. Plant Physiol 11, 1067-1075.

Paget, M. S., Kang, J. G., Roe, J. H. \& Buttner, M. J. (1998). SigmaR, an RNA polymerase sigma factor that modulates expression of the thioredoxin system in response to oxidative stress in Streptomyces coelicolor A3(2). EMBO J 17, 5776-5782.

Pasternak, C., Assemat, K., Clement-Metral, J. D. \& Klug, G. (1997). Thioredoxin is essential for Rbodobacter sphaeroides growth by aerobic and anaerobic respiration. Microbiology 143, 83-91.

Pille, S., Chuat, J. C., Breton, A. M., Clement-Metral, J. D. \& Galibert, F. (1990). Cloning, nucleotide sequence, and expression of the Rhodobacter sphaeroides Y thioredoxin gene. J Bacteriol 172, 1556-1561.

Rockey, D. D., Chesebro, B. B., Heinzen, R. A. \& Hackstadt, T. (1996). A $28 \mathrm{kDa}$ major immunogen of Chlamydia psittaci shares identity with Mip proteins of Legionella spp. and Chlamydia trachomatis - cloning and characterization of the C. psittaci miplike gene. Microbiology 142, 945-953.

Russel, M. \& Model, P. (1986). The role of thioredoxin in filamentous phage assembly. Construction, isolation, and characterization of mutant thioredoxins. J Biol Chem 261, 14997-15005.

Sambrook, J., Fritsch, E. F. \& Maniatis, T. (1989). Molecular
Cloning: a Laboratory Manual, 2nd edn. Cold Spring Harbor, NY: Cold Spring Harbor Laboratory.

Sanger, F., Nicklen, S. \& Coulson, A. R. (1977). DNA sequencing with chain-terminating inhibitors. Proc Natl Acad Sci USA 74, 5463-5467.

Scharf, C., Riethdorf, S., Ernst, H., Engelmann, S., Völker, U. \& Hecker, M. (1998). Thioredoxin is an essential protein induced by multiple stresses in Bacillus subtilis. J Bacteriol 180, 1869-1877.

Van Asseldonk, M., Simons, A., Visser, H., De Vos, W. M. \& Simons, G. (1993). Cloning, nucleotide sequence, and regulatory analysis of the Lactococcus lactis dnaJ gene. J Bacteriol 175, 1637-1644.

Wieles, B., Ottenhoff, T. H. M., Steenwijk, T. M., Franken, K., Devries, R. R. P. \& Langermans, J. A. M. (1997). Increased intracellular survival of Mycobacterium smegmatis containing the Mycobacterium leprae thioredoxin-thioredoxin reductase gene. Infect Immun 65, 2537-2541.

Yang, D. \& Woese, C. R. (1989). Phylogenetic structure of the Leuconostoc: an interesting case of rapidly evolving organism. Syst Appl Microbiol 12, 145-149.

Received 20 November 1998; revised 18 January 1999; accepted 21 January 1999. 



\title{
Structural and putative regulatory genes involved in cellulose synthesis in Rhizobium leguminosarum bv. trifolii
}

\author{
Nora Ausmees, ${ }^{1}$ Hans Jonsson, ${ }^{1}$ Stefan Höglund, ${ }^{2}$ Hans Ljunggren ${ }^{1}$ \\ and Martin Lindberg ${ }^{1}$
}

Author for correspondence: Nora Ausmees. Tel: +46 186732 06. Fax: +4618673392.
e-mail: nora.ausmees@mikrob.slu.se

1 Swedish University of

Agricultural Sciences, SLU,

Department of

Microbiology, Box 7025 ,

S-75007 Uppsala, Sweden

2 Uppsala University,

Department of

Biochemistry, Box 576,

S-75123 Uppsala, Sweden

\begin{abstract}
Six genes involved in cellulose synthesis in Rhizobium leguminosarum bv. trifolii were identified using In5 mutagenesis. Four of them displayed homology to the previously cloned and sequenced Agrobacterium tumefaciens cellulose genes celA, celB, ce/C and celE. These genes are organized similarly in $R$. leguminosarum bv. trifolii. In addition, there were strong indications that two tandemly located genes, celR1 and celR2, probably organized as one operon, are involved in the regulation of cellulose synthesis. The deduced amino acid sequences of these genes displayed a high degree of similarity to the Caulobacter crescentus DivK and PleD proteins that belong to the family of two-component response regulators. This is to our knowledge the first report of genes involved in the regulation of cellulose synthesis. Results from attachment assays and electron microscopic studies indicated that cellulose synthesis in R. leguminosarum bv. trifolii is induced upon close contact with plant roots during the attachment process.
\end{abstract}

Keywords: Rhizobium leguminosarum bv. trifolii, cellulose synthesis, two-component regulation

\section{INTRODUCTION}

Cellulose production has been documented in several bacterial genera such as Acetobacter, Agrobacterium, Rhizobium and Sarcina (Ross et al., 1991). Acetobacter xylinus (previously Acetobacter xylinum) has served as a model organism in studies of bacterial cellulose synthesis at the molecular and biochemical level (Wong et al., 1990; Saxena et al., 1990, 1991; Saxena \& Brown, 1995). Two operons from Agrobacterium tumefaciens with genes encoding proteins involved in cellulose synthesis (celABC and celDE) have also been characterized (Mathysse et al., 1995a, b). The results suggest that cellulose synthesis in these two organisms involves at least two homologous genes, a cellulose synthase and an endoglucanase. The other three genes in the $A g$. tumefaciens cel operons show no homology to known genes in Ac. xylinus, thus reflecting differences in the

Abbreviations: Amp, ampicillin; Km, kanamycin; Sm, streptomycin; Tet, tetracycline.

The GenBank accession numbers for the celABC and celR1-celR2 sequences determined in this work are AF121340 and AF121341, respectively. mechanisms of cellulose synthesis in these two bacteria. Matthysse et al. (1995b) have suggested a model pathway for cellulose production in Ag. tumefaciens. In this model, cellulose synthesis proceeds via several lipidlinked intermediates, involving the CelE and CelB proteins. A cellulose synthase (the product of the celA gene) adds additional glucose moieties to these lipidglucose intermediate products. The incorporation of the last intermediate into cellulose requires the CelC protein. The exact function of all the cel genes is not yet clear.

Here we report the cloning of genes involved in cellulose synthesis (the cel genes) from Rhizobium leguminosarum bv. trifolii. The primary sequence and the organization of the genes are similar to that of $\mathrm{Ag}$. tumefaciens (Mathysse et al., 1995a). In addition, we have identified two putative regulator genes, celR1 and celR2, probably organized as one operon and most likely controlling cellulose synthesis. According to the sequence composition, these genes belong to the family of two-component response regulators (Parkinson \& Kofoid, 1992). Surprisingly, they exhibit highest sequence homology to the Caulobacter crescentus pleD 
and $\operatorname{divK}$ genes, which are the key components in interconnecting polar morphogenesis and cell division events in this bacterium (Sommer \& Newton, 1989; Hecht et al., 1995; Hecht \& Newton, 1995).

The identification of genes involved in the synthesis of cellulose fibres opens the possibility to more precisely investigate the biological significance of these structures in Rhizobium.

\section{METHODS}

Bacterial strains, plasmids and growth media. The wild-type strain R200 is a spontaneus streptomycin- and rifampinresistant $\left(\mathrm{Sm}^{\mathrm{r}} \mathrm{R} \mathrm{if}^{\mathrm{r}}\right.$ ) mutant of $R$. leguminosarum bv. trifolii strain 2046 from the culture collection at the Department of Microbiology, Swedish University of Agricultural Sciences. Strain R201 is a cellulose-overproducing mutant obtained after NTG treatment of strain R200. Strains R204, R205, R206，R207，R211 and R214 are cellulose-negative Tn5 mutants generated from strain R201. Escherichia coli strains XL-1 Blue and DH5 $\alpha$ were used for cloning. The pUC18 and Bluescript plasmids were used for cloning and sequencing. Vector pRK404A was used as a broad-host-range plasmid in complementation experiments. It is a derivative of plasmid pRK404 (Ditta et al., 1985) with a unique EcoRI site in the multilinker, constructed by W. Buikema at the University of Chicago, USA. Plasmid pR K2013 (Figurski \& Helinski, 1979) was used as a helper plasmid in bacterial conjugations. Plasmid pSUP2021 (Simon et al., 1983) was used for Tn5 mutagenesis. Rhizobium strains were grown in TY medium $\left(l^{-1}: 5 \mathrm{~g}\right.$ tryptone, $3 \mathrm{~g}$ yeast extract and $1 \mathrm{~g} \mathrm{CaCl}_{2}$ ) or $\mathrm{YMB}$ medium $\left(1^{1}: 0.5 \mathrm{~g} \mathrm{~K}_{2} \mathrm{HPO}_{4}, 0.1 \mathrm{~g} \mathrm{NaCl}, 10 \mathrm{~g}\right.$ mannitol, $0.4 \mathrm{~g}$ yeast extract and $0 \cdot 2 \mathrm{~g} \mathrm{MgSO}_{4} \cdot 7 \mathrm{H}_{2} \mathrm{O}$ ), supplemented with Congo red $\left(25 \mathrm{mg} \mathrm{l}^{-1}\right)$ when needed. E. coli strains were grown in Luria-Bertani liquid (LB) or agar (LA) media. When appropriate, antibiotics were added at the following concentrations: ampicillin (Amp), $50 \mu \mathrm{g} \mathrm{ml}^{-1}$; kanamycin $(\mathrm{Km})$, $20 \mu \mathrm{g} \mathrm{ml}^{-1}$; tetracycline (Tet), $10 \mu \mathrm{g} \mathrm{ml}^{-1}$; and streptomycin $(\mathrm{Sm}), 20 \mu \mathrm{g} \mathrm{ml}^{-1}$.

Mutagenesis and isolation of mutants. Washed cells of $R$. leguminosarum bv. trifolii strain R200 (exponential-growth phase) were suspended in $10 \mathrm{ml} 0 \cdot 1 \mathrm{M}$ citrate buffer $\mathrm{pH} 5 \cdot 8$ to a cell density of $5 \times 10^{8}$ c.f.u. $\mathrm{ml}^{-1}$. Freshly dissolved NTG was added to a final concentration of $100 \mu \mathrm{g} \mathrm{ml}^{-1}$ (Adelbey et al., 1965). After incubation at $28{ }^{\circ} \mathrm{C}$ for $60 \mathrm{~min}$, the cells were washed in saline, suspended in $50 \mathrm{ml} \mathrm{YMB}$ and incubated at $28^{\circ} \mathrm{C}$ overnight to allow phenotypic expression. Celluloseoverproducing mutants were isolated as deep-red colonies after plating on YMB agar plates containing Congo red.

Random Tn5 mutagenesis of strain R201, forming deep-red colonies on YMB Congo red plates, was carried out using plasmid pSUP2021 as described by Simon et al. (1983). Cellulose-negative mutants were isolated as white colonies on YMB Congo red plates containing $\mathrm{Km}$.

Cloning and sequencing. DNA manipulations were performed according to standard protocols (Sambrook et al., 1989). Ligations were performed using the Ready-to-go kit from Pharmacia Biotech, and all plasmids were prepared using the QIAprep Spin Miniprep kit (Qiagen). DNA was sequenced using the Thermo sequenase dye terminator cycle sequencing kit (Amersham) and an ABI PRISM 337 DNA Sequencer (Perkin Elmer) according to protocols provided by the manufacturers. Sequences were analysed with the PC/GENE software package. Database searches were carried out using BLAST (Altschul et al., 1990). Protein alignments were carried out with the PC/GENE program PALIGN with parameters set at open gap cost 10 and unit gap cost 6 .

Complementation assay. DNA fragments used in the complementation assays were cloned into the broad-host-range vector $\mathrm{pRK} 404 \mathrm{~A}$. The recombinant plasmids were electroporated into $E$. coli $\mathrm{DH} 5 \alpha$ and introduced into strains $\mathrm{R} 200$ or R205 by triparental conjugation using the helper plasmid pRK2013 (Simon et al., 1983). Matings were performed by mixing $3 \times 10^{8}$ cells of both donor strains and $1.5 \times 10^{9}$ recipient cells from exponential-phase cultures and filtering the suspension onto $0.45 \mu \mathrm{m}$ Millipore filters. The filters were incubated for $3 \mathrm{~h}$ at $25^{\circ} \mathrm{C}$ on TY nonselective plates. Subsequently, the cells were resuspended and plated on YMB plates containing $\mathrm{Sm}$, Tet and Congo red.

Attachment assay. R. leguminosarum bv. trifolii strains were grown in TY medium until early stationary phase, washed twice with equal volumes of Fahraeus nitrogen-free medium (Fahraeus, 1957) and diluted five times with the same medium before being added to clover seedlings. The seedlings were produced from seeds of red clover $\mathrm{cv}$. Vivi incubated on water agar for $48-52 \mathrm{~h}$ in the dark. The binding assays were performed in two different ways, essentially as described by Smit et al. (1986) or by Dazzo et al. (1984), respectively. In the first case five seedlings were incubated in $10 \mathrm{ml}$ bacterial suspension in a $100 \mathrm{ml}$ flask at room temperature under slow shaking. In the second case the binding assay was performed on microscope slides as follows: five seedlings were placed on a microscope slide and $100 \mu \mathrm{l}$ bacterial suspension was dropped on the roots, which were then covered with a cover slide and stored at room temperature in a Petri dish sealed with Parafilm. Incubation time was varied from $2 \mathrm{~h}$ to overnight. After the incubation the seedlings were washed three times in $10 \mathrm{ml}$ Fahraeus medium under vigorous shaking. The attachment of the bacteria to the root hairs was evaluated under a phase-contrast microscope. All binding experiments were repeated at least three times.

Electron microscopy. Bacterial suspensions were analysed by different techniques: positive and negative staining and shadow casting to select optimal electron microscopic contrast. Since the diameter of the cellulose microfibrils produced by the bacteria should correspond approximately to that of double-stranded nucleic acid, the contrasting technique, which is used for DNA or RNA (Höglund \& Öhagen, 1997), was employed. Bacterial suspensions (taken directly from the growth medium or washed gently in $0.1 \mathrm{M}$ Tris buffer $\mathrm{pH} 7.5$ ) were adhered to carbon-coated grids, stained with $10^{-4} \mathrm{M}$ uranyl acetate and rinsed with $95 \%$ ethanol. Rotary shadowing with platinum was then employed at low angle $\left(8^{\circ}\right)$ to allow visualization of thin fibres. Specimens were analysed with a Zeiss CEM 902 electron microscope, equipped with a $\mathrm{N} 2$ (1) trap, at an accelerating voltage of $80 \mathrm{kV}$.

Nodulation test. Seeds of red clover cv. Brita were immersed for $5 \mathrm{~min}$ in a chlorhexidine/ethanol $(60 \%)$ solution $(5 \mathrm{mg}$ $\mathrm{ml}^{-1}$ ), washed in three changes of sterile water and distributed onto the surface of water agar plates, which were then incubated upside down for $2 \mathrm{~d}$ in the dark at room temperature. Seedlings with 5-7 mm roots were planted in the upper part of $10 \mathrm{ml}$ agar slopes of Jensen agar (Vincent, 1970) in $150 \times 20 \mathrm{~mm}$ tubes closed with transparent plastic caps. Tubes were illuminated for $16 \mathrm{~h}$ from a $400 \mathrm{~W}$ HPI-T lamp at $70 \mathrm{~cm}$ distance. After $2 \mathrm{~d}$ the seedling in each tube was inoculated with $1 \mathrm{ml}$ bacterial suspension prepared from $10 \mathrm{ml}$ 
sterile tap water with 2 loopfuls from 5-d-old colonies grown on YMB agar. After inoculation early nodulation was followed for 3 weeks.

\section{RESULTS AND DISCUSSION}

\section{Characterization of cellulose production in the overproducing mutant R201}

Most strains of R hizobium lack the ability to absorb the dye Congo red. However, there are exceptions to this generalized behaviour, as reported by Zevenhuizen et al. (1986). These authors showed that a few Rhizobium strains produced red to deep-red colonies on medium with Congo red and had cellulose contents of 2-10\% of their dry weights. Binding of Congo red was positively correlated to the presence of microfibrils as observed under the electron microscope and, furthermore, these fibrils disappeared upon treatment with cellulase. These data suggested to us that binding of Congo red could be used in screening for cellulose-overproducing mutants. Such strains with an increased cellulose production would be a basis for generating cellulose-negative mutants since most wild-type strains do not produce enough cellulose to acquire significant colour in the Congo-red-based plate assay.

The wild-type strain R200 (as most Rhizobium strains) forms white colonies on YEM plates with Congo red.
After mutagenesis of this strain with NTG, deep-redcoloured colonies appeared at a frequency of approximately $5 \times 10^{-4}$. One such mutant, here called R201, was selected for further studies. In comparison to the wildtype strain, the mutant strain R201 flocculated heavily when grown in YEM broth and produced a pellicle in static cultures. It also produced an alkali- and acidinsoluble substance that was degraded by cellulase but not by protease treatment (data not shown).

Electron microscopy of cells from strain R201 showed an abundance of fibres or bundles of fibres surrounding the bacteria. Negative staining visualized the fibres as relatively thick bundles or a meshwork of these bundles. It was difficult to determine any specific localization of these structures or the site of emergence from the cell membrane (Fig. 1a). To avoid these problems and to see if the appearance of the fibres was dependent on the method of preparation, rotation shadowing was used, a technique suitable for visualizing thin structures (Höglund \& Öhagen, 1997). Furthermore, the bacteria were not washed before application onto the grid to avoid aggregation of the cellulose. By this technique, much thinner microfibrils were seen emerging radially from all parts of the cell surface (Fig. 1b). A clear difference between these fibrils and the flagella was obvious (Fig. 1c). With reference to the thickness of flagella of 13-14 $\mathrm{nm}$ (Madigan et al., 1997), the diameter
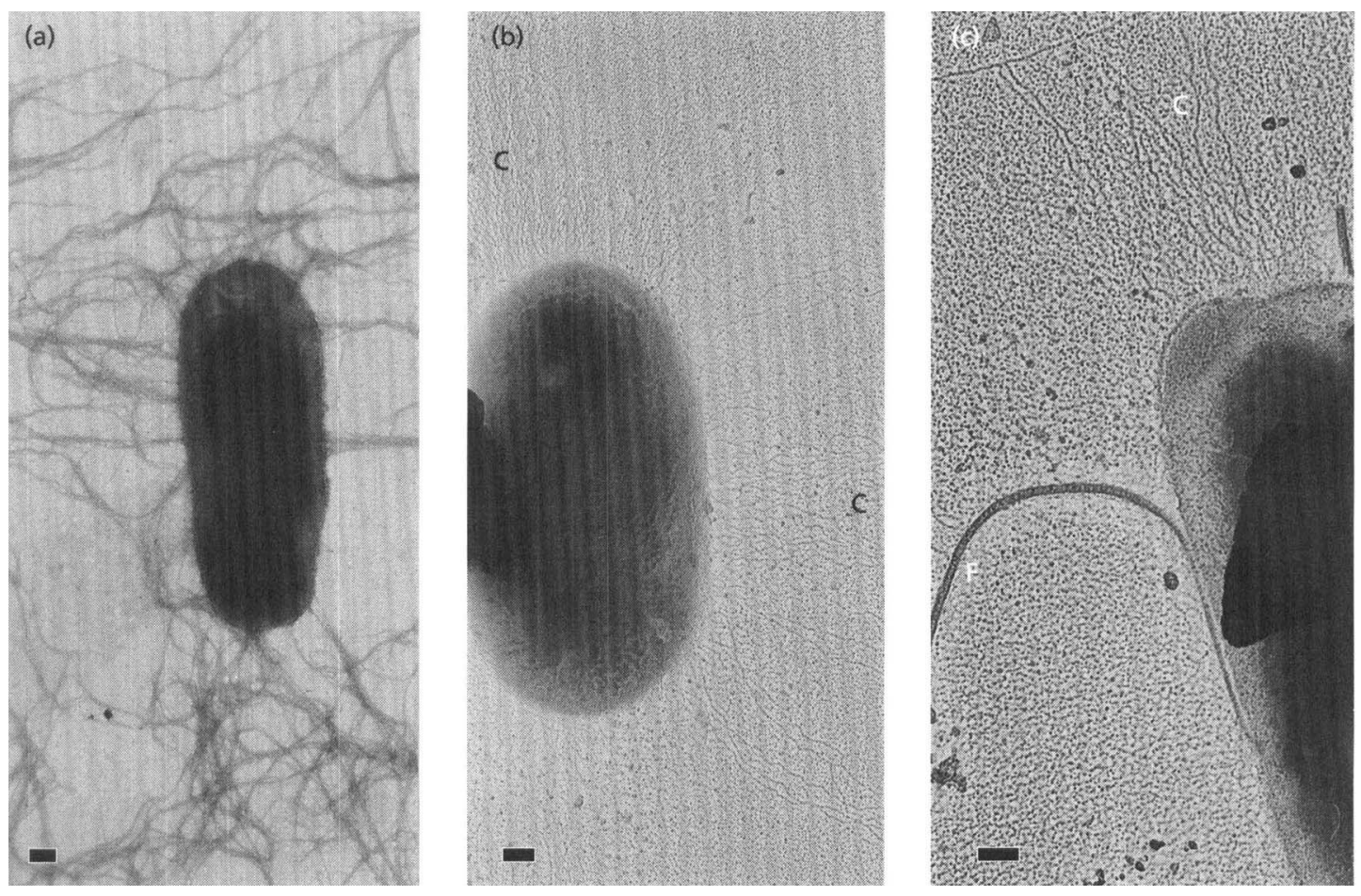

Fig. 1. Cellulose fibrils produced by R. leguminosarum bv. trifolii mutant strain R201. (a) Thick bundles of cellulose surrounding the cells (negative staining technique, washed cells). (b) Numerous thin cellulose fibrils (indicated by C) are seen emerging radially from the cells (rotary shadowing technique, unwashed cells). (c) Part of a bacterium showing a flagellum (F) and cellulose fibres (C). Bar, $100 \mathrm{~nm}$. 
of the microfibrils ranged from approximately 1 to $2 \mathrm{~nm}$. The fibrils are produced in the late exponential or early stationary phase since cells in early exponential phase were almost devoid of these fibrils, whereas most bacteria from an early-stationary-phase culture were heavily fibrillated. Cellulase treatment of the bacteria resulted in total disappearance of the fibrils.

According to Brown et al. (1976) and Wong et al. (1990), the newly polymerized subelementary cellulose strands in Ac. xylinus are extruded through pores in the outer membrane and crystallized into cellulose microfibrils by hydrogen bonding. The diameter of these microfibrils was reported to range between 1.6 and $5.8 \mathrm{~nm}$. The very thin fibres of $R$. leguminosarum bv. trifolii protruding from the cell membrane (Fig. 1 b, c) have a diameter of 1-2 nm and resemble the microfibrils described by Brown et al. (1976). The considerably thicker cellulosic structures visualized by negative staining (Fig. 1a) are probably aggregates of entwined fibrils.

Screening of 50 individual cells of the wild-type strain under the electron microscope did not detect any fibrillated cells. Likewise, no fibrils were detected on the cells of the cellulose-negative mutants R204 (celA:: Tn5) and R205 (celR2::Tn5) (see below). These strains formed white colonies on agar plates with Congo red, confirming that binding of the stain by the mutant R201 resulting in red colonies is correlated to high production of cellulose fibrils. Although it has been reported that Congo red also can bind to outer-membrane proteins of various Gram-negative, animal pathogenic bacteria (Theisen et al., 1993), our data support the observation by Zevenhuizen et al. (1986) that in Rhizobium the Congo red binding is related to the cellulose content of the bacteria. Thus in all subsequent experiments (e.g. the complementation of the cellulose-negative phenotype), the binding of Congo red was taken as a marker for cellulose production, without additional confirmative tests.

\section{Identification of genes involved in cellulose synthesis by Tn 5 mutagenesis}

The cellulose-overproducing strain R201 was subjected to Tn5 mutagenesis. The screening of cellulose nonproducing mutants was carried out on agar plates containing $\mathrm{Km}$ and Congo red. Eleven white colonies were isolated and total DNA from them prepared. The DNA was cleaved with EcoRI and subjected to Southern blot hybridization. In order to detect all possible insertion events, the whole pSUP2012 plasmid was cleaved with HindIII and used as template in the random priming labelling procedure to create a radioactive probe. All mutant strains showed a single radioactive band on the autoradiography plates. After prolonged cultivation some of the mutants exhibited weakly red or segmented colony types and were not investigated further. Six isolates, R204, R205, R206, R207, R211 and $\mathrm{R} 214$, gave stable white colonies on Congo red plates and were chosen for further analysis. The EcoRI fragments carrying the Tn5 insertions from all six strains were cloned into $\mathrm{pUC} 18$. Since $\mathrm{Tn} 5$ does not contain any EcoRI cleavage sites, the cloned fragments contained flanking rhizobial DNA. Nucleotide sequences obtained from these clones were compared to sequences in the nucleic acid and protein databases. The results showed that three mutants, R204, R206 and R214, had Tn5 inserted in a region showing high sequence homology to the Ag. tumefaciens celA gene, encoding a cellulose synthase (Matthysse et al., 1995a). Certain regions of the deduced protein sequence also showed homology to the Bsca, Axcs and Acsaii proteins, all three characterized as cellulose synthases in Ac. xylinus (Wong et al., 1990; Saxena et al., 1990; Saxena \& Brown, 1995). Tn5 flanking sequences from strains R207 and R211 showed strong homology to the Ag. tumefaciens cellulose genes $c e l E$ and $c e l B$, respectively, suggesting that the cellulose synthesis pathway in Rhizobium might be similar to that of Ag. tumefaciens (Matthysse et al., 1995a, b). The CelE protein in Ag. tumefaciens is proposed to attach UDP-glucose to a lipid carrier, forming a lipid intermediate product. The $c e l B$ gene product was also shown to be involved in the synthesis of lipid-linked intermediates, although the exact function of the protein is not known (Matthysse et al., 1995b).

Sequences obtained from strain R205 did not show homology to the Ag. tumefaciens cel operon. Instead, they indicated that the $\operatorname{Tn} 5$ insertion was located in a regulatory gene. The involvement of this gene in cellulose synthesis is described below.

\section{Organization of the cel genes is conserved in Rhizobium and Agrobacterium}

To establish the organization of the $R$. leguminosarum bv. trifolii cel genes, we took advantage of the sequence homology to the Ag.tumefaciens cel genes as revealed by the database search. Partial EcoRI cleavage products of total DNA from strains R207 and R211 were ligated into pUC18. The ligation mixtures were electroporated into E. coli $\mathrm{DH} 5 \alpha$ and transformants were selected on LA plates with Amp and $\mathrm{Km}$. From these clones, inserts from isolated plasmids, containing the putative flanking sequences of the previous EcoRI fragments, were analysed by EcoRI cleavage and sequencing (Fig. 2a-c). Comparison of the resulting DNA sequence with the homologous region in Ag. tumefaciens showed a similar organization of the corresponding genes in R. leguminosarum bv. trifolii (Fig. 2b). The sequence homology is limited to the region where the cellulose genes are located. Upstream of the celA and celE genes the sequences of $R$. leguminosarum bv. trifolii and Ag. tumefaciens diverge. The R. leguminosarum bv. trifolit cel $A B C$ operon was completely sequenced. Alignment of the deduced R. leguminosarum bv. trifolii and Ag. tumefaciens proteins indicated that the CelA proteins of the two species showed $69.5 \%$ identity and $80 \%$ similarity, the CelB proteins showed $49 \%$ identity and $62 \%$ similarity, and the CelC proteins showed $45 \%$ identity and $55 \%$ similarity in their amino acid 
(a)

(b)

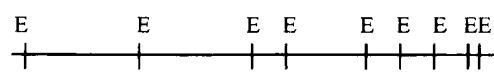

(c)

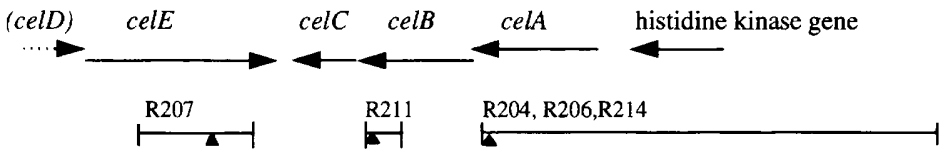

Fig. 2. Strategy for defining the structure of the $R$. leguminosarum bv. trifolii cel genes. (a) EcoRl map of the cel region. (b) The location and the orientation of the cel genes is analogous to that of $\mathrm{Ag}$. tumefaciens (Matthysse et al., 1995a). The celD gene, present in $A g$. tumefaciens but not detected in $R$. leguminosarum bv. trifolii, is depicted by a dotted line. (c) Some of the partial EcoRI clones of strains R207 (celE::Tn5) and R211 (celB::Tn5) are depicted below the original clones. Triangles indicate the $\mathrm{Tn} 5$ insertions. sequences. The sequence of the celA gene offers an ORF with three alternative start sites. No obvious ShineDalgarno (SD) sequence is present upsteam of the first and second ATG in the ORF, while the third ATG is preceded by a classical SD motif. This yields a deduced protein of 730 amino acids. Similarly, the $c e l A$ gene from Ag. tumefaciens also has two alternative initiation codons (GenBank accession no. L38609). Alignment of the deduced CelA proteins from Ag. tumefaciens and $R$. leguminosarum bv. trifolii showed sequence homology starting from the second and the third methionine, respectively. The CelA sequence was also similar to several cellulose synthases from other organisms, for example Ac.xylinus, Aquifex and Arabidopsis, and also to a hypothetical protein of unknown function from $E$. coli and to NodC proteins ( $\mathrm{N}$-acetylglucosaminyltransferase, involved in the synthesis of nod factors) from several Rhizobium species, as revealed by a BLAST database search. The $c e l B$ gene begins at a start codon overlapping the celA stop codon. The deduced $R$. leguminosarum bv. trifolii CelB protein (822 amino acids) was somewhat longer than Ag.tumefaciens CelB (698 amino acids). Alignment of the two CelB proteins showed a highly conserved part near the $C$ terminus, displaying $78 \%$ amino acid sequence similarity between amino acids 410 and 640 . In the N-terminus of both proteins there was a domain of 110 amino acids rich in prolines, although there was no high score in pairwise alignment. The stop codon for $R$. leguminosarum bv. trifolii celB overlapped the start codon for $c e l C$ and was situated approximately $320 \mathrm{bp}$ downstream of the proposed site for the Ag. tumefaciens celC start codon. Thus the same pattern of overlapping stop and start codons was observed for these three genes in $R$. leguminosarum bv. trifolii, indicating that the synthesis of the proteins is coupled. CelC protein showed significant sequence similarity to several bacterial endoglucanases, among them the Ac. xylinus CMCax protein, encoded by a gene linked to the cellulose synthase operon (Standal et al., 1994). The involvement of a cellulase thus seems to be a common feature in the cellulose production pathway in Acetobacter, Agrobacterium and Rhizobium. $R$. leguminosarum bv. trifolii is also reported to possess extracellular, cell- associated cellulase activity (Mateos et al., 1992). However, at present there are no data available to correlate this activity to CelC.

The celE region was partially sequenced. The sequence data indicated the presence of a gene with considerable sequence similarity to Ag. tumefaciens celE, located downstream of the $c e l C$ gene. Sequences obtained from the DNA region located immediately upstream of the celE gene did not display similarity to Ag. tumefaciens celD.

Interestingly, a gene with strong homology to sensor histidine kinases is situated just upstream of the celA gene (Fig. 2b). In a BLAST database search, the FixL protein from $R$. leguminosarum showed the highest score. FixL is an oxygen sensor and transduces the low oxygen signal by controlling the phosphorylation of FixJ protein (a transcriptional activator). Sequence similarities covered only the C-terminal kinase part of the FixL protein (Lois et al., 1993). No similarities were detected between the membrane-spanning region and the haem-binding domains of FixL and the N-terminal sequence of the putative kinase. The possibility that this gene encodes the cognate kinase for the putative response regulators CelR1 and CelR2, involved in the regulation of the cellulose synthesis (see below), will be tested in the future.

\section{Identification of putative components of a signalling pathway involved in cellulose synthesis}

Sequence comparisons showed that the gene inactivated by $\operatorname{Tn} 5$ in strain R 205 is homologous to several response regulators belonging to the so-called two-component regulatory systems. We named the new regulator gene celR2. Besides the similarity to the conserved N-terminal parts of several response regulators, the deduced amino acid sequence of $c e l R 2$ shows high sequence homology to C. crescentus PleD (Hecht \& Newton, 1995) throughout its entire length (Fig. 3). In C. crescentus, the regulatory genes pleC (a histidine kinase) and pleD and $\operatorname{divK}$ (the cognate response regulators), are the key elements in coupling shifts in polar morphogenesis to cell cycle events (Sommer \& Newton, 1989; Hecht et 


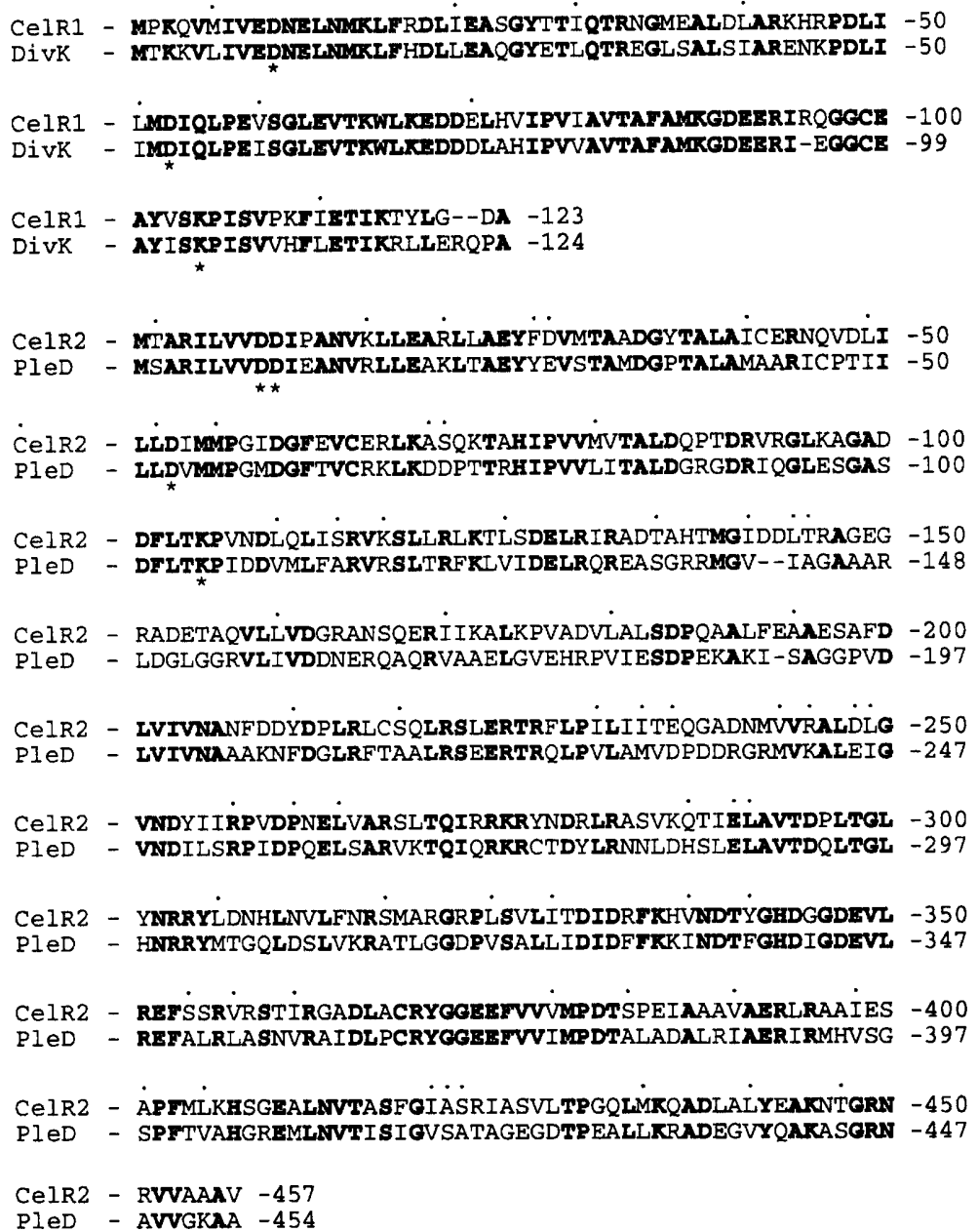

Fig. 3. Alignment of the C. crescentus DivK and PleD proteins (Hecht et al., 1995; Hecht \& Newton, 1995) with the corresponding proteins, CelR1 and CelR2, in $R$. leguminosarum bv. trifolii. The alignment was carried out using the PC/GENE program PALIGN. Bold letters indicate identical amino acids, dots indicate similar amino acids and asterisks represent conserved amino acids involved in phosphorylation in response regulators. The DivK and CelR1 proteins exhibit $74 \%$ identity and $83.7 \%$ similarity, and the PleD and CelR2 proteins exhibit $50.2 \%$ identity and $64.3 \%$ similarity, in their amino acid composition. al., 1995; Hecht \& Newton, 1995; Wang et al., 1993). The divK and pleD genes in C. crescentus are situated immediately next to each other (Hecht \& Newton, $1995)$. Interestingly, sequencing the upstream region of celR 2 revealed a gene with very high sequence homology to divK (Fig. 3). In R. leguminosarum bv. trifolii these two genes are also located close to each other, being separated by only $18 \mathrm{bp}$. The $R$. leguminosarum bv. trifolii divK homologue, named celR1, encodes a protein of 123 amino acids, and celR2 encodes a protein of 457 amino acids. In C. crescentus, both DivK and PleD regulators are phosphorylated by the same histidine kinase, PleC. DivK is an essential cell division regulator (Hecht et al., 1995) and PleD is required in the regulation of polar morphogenesis during the swarmer-to-stalkedcell transition (Hecht \& Newton, 1995). Interestingly, Rhizobium is also a polar bacterium in the sense that the bacteria adhere to the root hairs with one cell pole (Marshall et al., 1975; Maddock et al., 1993; Höflich et al., 1995). Bradyrhizobium japonicum produces a polar lectin (Ho et al., 1994) and also displays intracellular asymmetry concerning the localization of reserve polymers (Tsien \& Schmidt, 1977). Dazzo et al. (1982) showed that plant extracts caused polar changes in the structure of the capsule in R. leguminosarum bv. trifolii.
However, this polar behaviour is so far not explained at the molecular level. It is an intriguing possibility that the celR1-celR2 regulatory system might in some way be involved in maintaining the polarity in dividing $R h_{i}$ zobium cells. There may also be other traits that are coregulated with cellulose synthesis.

Cellulose synthesis in strain R201 is not polar. The electron microscopy study clearly showed that the cell surface of the overproducing strain was completely covered by cellulose. However, the attachment of these cells to the root hairs was clearly polar as seen under the phase-contrast microscope (data not shown). The same polar attachment was also observed both for the wildtype and the cellulose-negative strain R204 (celA: : Tn5).

\section{The cloned celR1-celR2 genes complement the R205 $\mathrm{Cel}^{-}$phenotype and trigger cellulose overproduction in wild-type R200}

To confirm the involvement of celR regulators in cellulose synthesis, complementation of the celR $2 \mathrm{mu}$ tation in strain R205 (celR2:: Tn5) was carried out with the functional regulator region cloned from the overproducing strain R201. A HindIII fragment of approxi- 


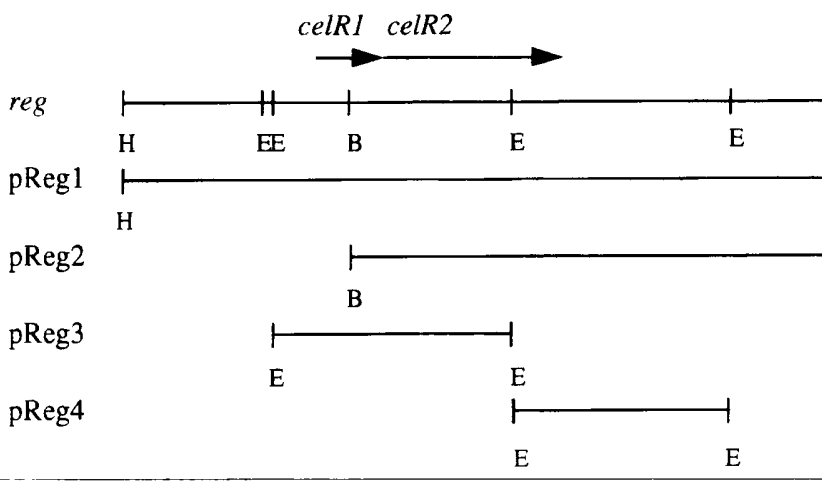

\begin{abstract}
Fig. 4. Complementation of the $\mathrm{Cel}^{-}$ phenotype of R205 (ce/R2::Tn5) with different DNA fragments from the reg region. The reg region is a $\sim 6.5 \mathrm{~kb}$ Hindlil fragment containing both regulator genes celR1 and celR2 and flanking DNA. The corresponding fragments were cloned into PRK404A, generating the clones pReg1-pReg4 and then conjugated into $\mathrm{R} 205$. The restriction map of the reg region and the location of the fragments is shown. E, EcoRI; H, Hindlll; B, BamHI. + indicates full complementation (bright red colonies on Congo red plates after conjugation), $-/(+)$ indicates incomplete or delayed complementation (originally white colonies turning pale red after a prolonged incubation), and-indicates no complementation (white colonies).
\end{abstract}

mately $6 \mathrm{~kb}$, containing both regulator genes (the reg region; Fig. 4), was cloned into the broad-host-range vector $p R K 404 \mathrm{~A}$ and transferred into R205 in a triparental conjugation. This construct, pReg1, completely restored cellulose overproduction in R205 as shown by the intense red colour of the transconjugant colonies on Congo red plates. Deletion clones from the original HindIIl insert were created and their complementation ability was tested. The results are summarized in Fig. 4. A shorter HindIII/BamHI fragment of the reg region (pReg2) partially complemented R205. This was manifested as the emergence of white transconjugant colonies 3-5 d after plating on Congo red plates. After prolonged incubation for more than $7 \mathrm{~d}$, these colonies turned pale red, whilst the colonies of the cellulose-negative strain (containing the vector plasmid) remained white.

Plasmid pReg3, containing a $2 \mathrm{~kb}$ EcoRI fragment, failed to complement the mutation in R205. This plasmid contains the intact celR1 and the upstream region but lacks 249 bp from the $3^{\prime}$ end of the celR 2 gene. As expected, the pReg 4 construct, containing the $3^{\prime}$ end of the $c e l R 2$ gene and the downstream region, was also incapable of complementation.

The complementation analysis supported the requirement for the celR1-celR2 tandem gene structure in the activation of cellulose synthesis in $R$. leguminosarum bv. trifolii. The fact that the pReg2 construct, lacking the proximal region of the celR 1 gene, only showed weak and delayed complementation, indicates that celR 1 and celR2 are organized in an operon. Although the transconjugants received an intact $c e l R 2$, this was not sufficient for effective complementation. The reason for the weak expression after prolonged incubation in our transconjugants, despite the lack of the celR1 promoter, is unclear, but might be explained by spurious transcription from within the vector sequence. In $C$. crescentus, these two genes are coupled and transcription is initiated from a single promoter upstream of $\operatorname{divK}$. A construct containing the promoterless $\operatorname{div} K$ and ple $D$ region failed to complement the pleD defect (Hecht \& Newton, 1995).
Interestingly, the construct pReg 1 also caused cellulose overproduction in the wild-type R200 when this strain was used as a recipient in the conjugation experiments. As the pReg1 construct, containing the reg region from the overproducing strain R201, might carry a mutation, the corresponding HindIII fragment (wild-type reg region) was cloned from strain R200 and designated $\mathrm{pRegW}$. The conjugative transfer of plasmid $\mathrm{pRegW}$ into strains R205 and R200 yielded bright red transconjugant colonies in both cases. No visual difference was observed between transconjugant colonies harbouring pReg1 or pRegW on Congo red plates. This shows clearly that the enzymic machinery for cellulose production is fully functional in the wild-type R200, and can be triggered by increasing the gene dosage of celR1-celR2. This result further strengthens our hypothesis that celR1 and celR2 are involved in the regulation of cellulose synthesis. An example of a similar gene dosage effect was reported concerning the regulation of virulence (vir) genes in Ag. tumefaciens, where increasing the gene dosage of a response regulator gene (virG) resulted in increased vir gene expression and elevation of virulence (Jin et al., 1987; Rogowsky et al., 1987).

\section{Nodulation assay}

All R. leguminosarum bv. trifolii strains described in this paper were capable of nodulating red clover under the assay conditions used (data not shown). This result agrees with data published by Smit et al. (1987) who also compared cellulose-producing strains and cellulosenegative mutants for their ability to nodulate, without seeing any differences in this respect.

\section{Cellulose synthesis is probably an induced event in $R$. leguminosarum bv. trifolii as indicated by attachment assays}

Since cellulose fibres were undetectable by electron microscopy of wild-type $R$. leguminosarum bv. trifolii cells, we tested the different strains for their ability to 
attach to the root hairs of clover seedlings. Earlier reports showed that the firm attachment and especially the formation of large aggregates of bacteria on root hair tips (so-called 'cap formation') is an attribute of the cellulose fibres (Napoli et al., 1975; Matthysse et al., 1981; Smit et al., 1986, 1987, 1992). According to Smit et al. (1987), the caps are formed during the first $2 \mathrm{~h}$ of the attachment process.

We carried out binding assays essentially as described by Smit et al. (1986). The strains tested were wild-type $R$. leguminosarum bv. trifolii R200, the cellulose overproducing mutant R201 and the cellulose-negative $\mathrm{Tn} 5$ mutants R204 (celA::Tn5) and R205 (celR2::Tn5). After $2 \mathrm{~h}$ incubation with R201, virtually all root hairs had large clumps of adhered bacteria (caps) around the root hair tips and along the root hairs. Besides aggregates, we also observed single cells attached polarly to the different parts of the root. Strains R200, R204 and R205 behaved differently from strain R201. After $2 \mathrm{~h}$ incubation, $90 \%$ of the root hairs were covered with single cells attached to the tip and stem region. No bacterial aggregates were seen on the root hairs of the seedlings incubated with these bacteria. Even after prolonged incubation times of up to $16 \mathrm{~h}$, no visible caps were formed. All three strains displayed this single cell type of attachment. Assuming a direct correlation between cap formation and the presence of cellulose fibres, this result indicated that the wild-type R200 did not produce cellulose under these conditions as its attachment behaviour was indistinguishable from that of the cellulose-negative mutants. This conclusion is strengthened by the fact that we failed to see cellulose fibres on the R200 cells from a liquid culture under the electron microscope (see above).

An alternative strategy for studying attachment was described by Dazzo et al. (1984). These authors observed the synthesis of extracellular fibrils only after $12 \mathrm{~h}$ incubation in an undisturbed hydroponic slide culture. We repeated this experiment with the wild-type and the cellulose-negative mutants. After $2 \mathrm{~h}$ incubation, only single cell attachment was seen for all strains. However, after overnight incubation, some aggregation of the wild-type bacteria around the root hair tips was observed, whilst the binding pattern of the cellulosenegative strains remained unchanged.

Smit et al. (1992) presented a two-step attachment model in which the protein rhicadhesin was responsible for specific binding of the bacteria to plant roots and the cellulose fibres were required for the second stage of firm anchoring and floc or cap formation. Cellulose production in $R$. leguminosarum was considered to be constitutive by these authors (Smit et al., 1987). On the other hand, cellulose synthesis in Ag. tumefaciens has been shown to be induced by plant extracts (Matthysse et al., 1981). Earlier data presented by Dazzo et al. (1984) also indicated that cellulose synthesis in $R$. leguminosarum bv. trifolii was induced by some compounds in root exudates. Our data are in agreement with Dazzo et al. (1984) and indicate that cellulose production in $R$. leguminosarum bv. trifolii is induced by contact between roots and bacteria. The identification of genes probably involved in the regulation of synthesis of cellulose (see above) strengthens that observation. The deduced structure of these regulators suggests that they are involved in a signalling pathway. The data obtained so far allow us to hypothesize that some plant-derived compound(s) may act as signal(s) for turning on cellulose synthesis in $R$. leguminosarum bv. trifolii, and that CelR1 and CelR2 are likely components of such a signal transduction pathway.

The attachment mechanisms are considered to be similar in Rhizobium and Agrobacterium, proceeding according to the two-step attachment model (Smit et al., 1992). The protein rhicadhesin, mediating the first stage in the attachment process, is compatible between members of the family Rhizobiaceae (Smit et al., 1989; Swart et al., 1993). Cellulose fibres are involved in the second attachment stage to ensure the firm binding and aggregation of bacteria around a possible infection site. A similar model was also proposed for the attachment behaviour of Azospirillum bacteria (Michiels et al., 1991; Vande Broek \& Vanderleyden, 1995), where a flagellar protein mediates the first binding step and a Calcofluor-binding polysaccharide is responsible for the second firm attachment step. In Ag. tumefaciens, the cellulose fibrils serve to bind the bacteria tightly to the plant host cells and mutants which cannot synthesize cellulose are reduced in virulence, but still capable of infection, at least under laboratory conditions (Matthysse et al., 1981; Minnemeyer et al., 1991). Similarly, Smit et al. (1987) showed that fibril-negative as well as fibril-overproducing mutants of $R$. leguminosarum showed a normal nodulation behaviour, which was confirmed for $R$. leguminosarum bv. trifolii in the present study. Thus although the second binding step seems to be conserved among different bacteria it is not a prerequisite for a successful interaction.

The structural and putative regulatory genes described in this report will be the basis for making suitable reporter gene constructs to further investigate the environmental signalling process leading to cellulose production in these bacteria.

\section{ACKNOWLEDGEMENTS}

This work was supported by a grant from the Swedish Council for Forestry and Agricultural Research (32.0371/96) and Carl Trygger's Foundation for Scientific Research to M.L.

We thank Professor Gerhart Wagner for helpful discussions and critical reading of the manuscript.

\section{REFERENCES}

Adelbey, E. D., Mandel, M. \& Chen, G. C. C. (1965). Optimal conditions for mutagenesis by $N$-methyl- $N^{\prime}$-nitrosoguanidine in Escherichia coli K12. Biochem Biophys Res Commun 18, 788-795.

Altschul, S. F., Gish, W., Miller, W., Myers, E. W. \& Lipman, D. J. (1990). Basic local alignment search tool. J Mol Biol 215, 403-410.

Brown, M. R., Willison, J. H. M. \& Richardson, C. L. (1976). Cellulose biosynthesis in Acetobacter xylinum: visualization of 
the site of synthesis and direct measurement of the in vivo process. Proc Natl Acad Sci USA 73, 4565-4569.

Dazzo, F. B., Truchet, G. L., Sherwood, J. E., Hrabak, E. M. \& Gardiol, A. (1982). Alteration of the trifoliin A-binding capsule of Rhizobium trifolii 0403 by enzymes released from clover roots. Appl Environ Microbiol 44, 478-490.

Dazzo, F. B., Truchet, G. L., Sherwood, J. E., Hrabak, E. M., Abe, M. \& Pankratz, S. H. (1984). Specific phases of root hair attachment in the Rhizobium trifolii-clover symbiosis. Appl Environ Microbiol 48, 1140-1150.

Ditta, G., Schmidhauser, T., Yakobson, E., Lu, P., Liang, X.-W., Finlay, D. R., Guiney, D. \& Helinski, D. R. (1985). Plasmids related to the broad host range vector, pRK290, useful for gene cloning and for monitoring gene expression. Plasmid 13, 149-153.

Fahraeus, G. (1957). The infection of clover root hairs by nodule bacteria studied by a simple glass slide technique. J Gen Microbiol 16, 374-381.

Figurski, D. H. \& Helinski, D. R. (1979). Replication of an origincontaining derivative of plasmid RK2 dependent on a plasmid function provided in trans. Proc Natl Acad Sci USA 76, $1648-1652$.

Hecht, G. B. \& Newton, A. (1995). Identification of a novel response regulator required for the swarmer-to-stalked-cell transition in Caulobacter crescentus. J Bacteriol 177, 6223-6229.

Hecht, G. B., Lane, T., Ohta, N., Sommer, J. M. \& Newton, A. (1995). An essential single domain response regulator required for normal cell division and differentiation in Caulobacter crescentus. EMBO / 14, 3915-3924.

Ho, S.-C., Wang, J. J., Schindler, M. \& Loh, J. T. (1994). Carbohydrate binding activities of Bradyrhizobium japonicum. III. Lectin expression, bacterial binding, and nodulation efficiency. Plant J 5, 873-884.

Höflich, G., Wiehe, W. \& Hecht-Buchholz, C. (1995). Rhizosphere colonization of different crops with growth promoting Pseudomonas and Rhizobium bacteria. Microbiol Res 150, 139-147.

Höglund, S. \& Öhagen, Å. (1997). Ultrastructure of HIV-1 genomic RNA. Virology 233, 271-279.

Jin, S., Komari, T., Gordon, M. P. \& Nester, E. W. (1987). Genes responsible for the supervirulence phenotype of Agrobacterium tumefaciens A281. J Bacteriol 169, 4417-4425.

Lois, A. F., Weinstein, M., Ditta, G. S. \& Helinski, D. R. (1993). The oxygen sensor FixL of Rhizobium meliloti is a membrane protein containing four possible transmembrane segments. J Bacteriol 175, 1103-1109.

Maddock, J. R., Alley, M. R. K. \& Shapiro, L. (1993). Polarized cells, polar actions. J Bacteriol 175, 7125-7129.

Madigan, M. T., Martinko, J. M. \& Parker, J. (1997). Cell biology. In Brock Biology of Microorganisms, 8th edn, pp. 83-86. London: Prentice-Hall.

Marshall, K. C., Cruikshank, R. H. \& Bushby, H. V. A. (1975). The orientation of certain root-nodule bacteria at interfaces, including legume root-hair surfaces. J Gen Microbiol 91, 198-200.

Mateos, P. F., Jimenez-Zurdo, J. I., Chen, J., Squartini, A. S., Haack, S. K., Martinez-Molina, E., Hubell, D. \& Dazzo, F. B. (1992). Cell-associated pectinolytic and cellulolytic enzymes in $\mathrm{Rhi}$ zobium leguminosarum biovar trifolii. Appl Environ Microbiol 58, 1816-1822.

Matthysse, A. G., Holmes, K. V. \& Gurlitz, R. H. G. (1981). Elaboration of cellulose fibers by Agrobacterium tumefaciens during attachment to carrot cells. J Bacteriol 145, 583-595.

Matthysse, A. G., White, S. \& Lightfoot, R. (1995a). Genes required for cellulose synthesis in Agrobacterium tumefaciens, J Bacteriol 177, 1069-1075.

Matthysse, A. G., Thomas, D. L. \& White, A. R. (1995b). Mechanism of cellulose synthesis in Agrobacterium tumefaciens. $J$ Bacteriol 177, 1076-1081.

Michiels, K., Croes, C. \& Vanderleyden, J. (1991). Two different modes of attachment of Azospirillum brasilense $\mathrm{Sp} 7$ to wheat roots. J Gen Microbiol 137, 2241-2246.

Minnemeyer, S. L., Lightfoot, R. \& Matthysse, A. G. (1991). A semiquantitative bioassay for relative virulence of Agrobacterium tumefaciens strains on Bryophyllum daigremontiana. J Bacteriol 173, 7723-7724.

Napoli, C., Dazzo, F. \& Hubell, D. (1975). Production of cellulose microfibrils by Rhizobium. Appl Microbiol 33, 123-131.

Parkinson, J. S. \& Kofoid, E. C. (1992). Communication modules in bacterial signalling proteins. Annu Rev Genet 26, 71-112.

Rogowsky, P. M., Close, T. J., Chimera, J. A., Shaw, J. J. \& Kado, C. I. (1987). Regulation of the vir genes of Agrobacterium tumefaciens plasmid pTiC58. J Bacteriol 169, 5101-5112.

Ross, P., Mayer, R. \& Benziman, M. (1991). Cellulose biosynthesis and function in bacteria. Microbiol Rev 55, 35-58.

Sambrook, J., Fritsch, E. F. \& Maniatis, T. (1989). Molecular Cloning: a Laboratory Manual, 2nd edn. Cold Spring Harbor, NY: Cold Spring Harbor Laboratory.

Saxena, I. M. \& Brown, R. M., Jr (1995). Identification of a second cellulose synthase gene (acsAII) in Acetobacter xylinum. J Bacteriol 177, 5276-5283.

Saxena, I. M., Lin, F. C. \& Brown, R. M., Jr (1990). Cloning and sequencing of the cellulose synthase catalytic subunit gene of Acetobacter xylinum. Plant Mol Biol 15, 673-683.

Saxena, I. M., Lin, F. C. \& Brown, R. M., Jr (1991). Identification of a new gene in an operon for cellulose biosynthesis in Acetobacter xylinum. Plant Mol Biol 16, 945-957.

Simon, R., Priefer, U. \& Puhler, A. (1983). A broad host range mobilization system for in vivo genetic engineering: transposon mutagenesis in Gram-negative bacteria. Bio/Technology 1, 784-791.

Smit, G., Kijne, J. W. \& Lugtenberg, B. J. J. (1986). Correlation between extracellular fibrils and attachment of Rhizobium leguminosarum to pea root hair tips. J Bacteriol 168, 821-827.

Smit, G., Kijne, J. W. \& Lugtenberg, B. J. J. (1987). Involvement of both cellulose fibrils and a $\mathrm{Ca}^{2+}$-dependent adhesin in the attachment of Rhizobium leguminosarum to pea root hair tips. $J$ Bacteriol 169, 4294-4301.

Smit, G., Logman, J. J., Boerrigter, M. E. T. I., Kijne, J. W. \& Lugtenberg, B. J. J. (1989). Purification and partial characterization of the Rhizobium leguminosarum biovar viciae $\mathrm{Ca}^{2+}$ dependent adhesin, which mediates the first step in attachment of cells of the family R hizobiaceae to plant root hair tips. J Bacteriol 171, 4054-4062.

Smit, G., Swart, S., Lugtenberg, B. J. J. \& Kijne, J. W. (1992). Molecular mechanisms of attachment of Rhizobium bacteria to plant roots. Mol Microbiol 6, 2897-2903.

Sommer, J. M. \& Newton, A. (1989). Turning off flagellum rotation requires the pleiotropic gene pleD: ple $A, p l e C$ and $p l e D$ define two morphogenic pathways in Caulobacter crescentus. J Bacteriol 171, 392-401.

Standal, R., Iversen, T.-G., Coucheron, D. H., Fjaervik, E., Blatny, J. M. \& Valla, S. (1994). A new gene required for cellulose production and a gene encoding cellulolytic activity in Acetobacter xylinum are colocalized with the bcs operon. J Bacteriol $176,665-672$. 
Swart, S., Smit, G., Lugtenberg, B. J. J. \& Kijne, J. W. (1993). Restoration of attachment, virulence and nodulation of Agrobacterium tumefaciens chvB mutants by rhicadhesin. Mol Microbiol 10, 597-605.

Theisen, M., Rioux, C. R. \& Potter, A. A. (1993). Molecular cloning, nucleotide sequence, and characterization of $l p p B$, encoding an antigenic 40-kilodalton lipoprotein of Haemophilus somnus. Infect Immun 61, 1793-1798.

Tsien, H. C. \& Schmidt, E. L. (1977). Polarity in the exponential phase Rhizobium japonicum cell. Can J Microbiol 23, 1274-1284. Vande Broek, A. \& Vanderleyden, J. (1995). The role of bacterial motility, chemotaxis, and attachment in bacteria-plant interactions. Mol Plant-Microbe Interact 8, 800-810.

Vincent, J. M. (1970). A Manual for the Practical Study of Root- nodule Bacteria. IBP handbook 15. Oxford: Blackwell Scientific Publications.

Wang, S. P., Sharma, P. L., Schoenlein, P. W. \& Ely, B. (1993). A histidine protein kinase is involved in polar organelle development in Caulobacter crescentus. Proc Natl Acad Sci USA 90, 630-634.

Wong, H. C., Fear, A. L., Calhoon, R. D. \& 10 other authors (1990). Genetic organization of the cellulose synthase operon in Acetobacter xylinum. Proc Natl Acad Sci USA 87, 8130-8134.

Zevenhuizen, L. P. T. M., Bertocci, C. \& van Neerven, A. R. W. (1986). Congo red absorption and cellulose synthesis by Rhizobiaceae. Antonie Leenwenhoek 52, 381-386.

Received 16 November 1998; revised 1 February 1999; accepted 4 February 1999. 